OECD Economics Department Working Papers No. 1529

Boosting productivity

and inclusiveness

in Lithuania

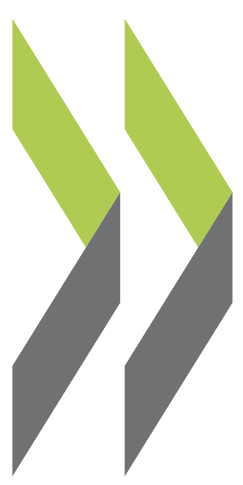

\section{Vassiliki}

Koutsogeorgopoulou,

Demetrio Guzzardi 


\section{BOOSTING PRODUCTIVITY AND INCLUSIVENESS IN LITHUANIA}

\section{ECONOMICS DEPARTMENT WORKING PAPERS No. 1529}

\section{By Vassiliki Koutsogeorgopoulou and Demetrio Guzzardi}

OECD Working Papers should not be reported as representing the official views of the OECD or its member countries. The opinions expressed and arguments employed are those of the authors.

Authorised for publication by Patrick Lenain, Assistant Director, Country Studies Branch, Economics Department.

All Economics Department Working Papers are available at www.oecd.org/eco/workingpapers

JT03441290 
OECD Working Papers should not be reported as representing the official views of the OECD or of its member countries. The opinions expressed and arguments employed are those of the author(s).

Working Papers describe preliminary results or research in progress by the author(s) and are published to stimulate discussion on a broad range of issues on which the OECD works.

Comments on Working Papers are welcomed, and may be sent to OECD Economics Department, 2 rue André-Pascal, 75775 Paris Cedex 16, France, or by e-mail to eco.contact@oecd.org.

All Economics Department Working Papers are available at www.oecd.org/eco/workingpapers.

This document and any map included herein are without prejudice to the status of or sovereignty over any territory, to the delimitation of international frontiers and boundaries and to the name of any territory, city or area.

The statistical data for Israel are supplied by and under the responsibility of the relevant Israeli authorities. The use of such data by the OECD is without prejudice to the status of the Golan Heights, East Jerusalem and Israeli settlements in the West Bank under the terms of international law.

On 25 May 2018, the OECD Council invited Colombia to become a Member. At the time of preparation the deposit of Colombia's instrument of accession to the OECD Convention was pending and therefore Colombia does not appear in the list of OECD Members and is not included in the OECD zone aggregates.

(C) $\operatorname{OECD}(2018)$

You can copy, download or print OECD content for your own use, and you can include excerpts from OECD publications, databases and multimedia products in your own documents, presentations, blogs, websites and teaching materials, provided that suitable acknowledgment of $\mathrm{OECD}$ as source and copyright owner is given. All requests for commercial use and translation rights should be submitted to rights@oecd.org 


\section{ABSTRACT/RÉSUME}

\section{Boosting productivity and inclusiveness in Lithuania}

Productivity growth in Lithuania has slowed in the aftermath of the global financial crisis, holding back income convergence and making it harder to reduce further the relatively high inequality and poverty. A comprehensive approach is required to address productivity and inclusiveness challenges, building on their synergies. The government has taken measures to this end, with the New Social Model at the core, but efforts need to continue. Reforms should focus on additional improvements in the business environment by easing further regulations on the employment of non-EU workers and reducing informality. Initiatives to improve the governance of state-owned enterprises are welcome and need to continue. Improving access to finance and ensuring effective bankruptcy procedures are key to boosting firm dynamism, as are measures to encourage business-research sector collaboration on innovation. Addressing large skills mismatch is also a priority. Increasing the market-relevance of the education system is important. More and better-quality jobs in the formal sector, especially for the low-skilled, are key to inclusiveness and well-being, while more effective support and active labour market programmes would help combating poverty.

This Working Paper relates to the 2018 OECD Economic Survey of Lithuania (www.oecd.org/eco/surveys/economic-survey-ireland.htm)

JEL classification: D31, J24, I24, I30, J31, O31

Keywords: Lithuania, benefits, inclusiveness, inequality, innovation, financing productivity, poverty, education, skills mismatch, employment protection legistation.

$* * * * * *$

\section{Stimuler la productivité et l'inclusivité en Lituanie}

La croissance de la productivité en Lituanie a ralenti au lendemain de la crise financière mondiale, freinant la convergence des revenus et rendant plus difficile la réduction supplémentaire de la pauvreté et des inégalités, qui sont actuellement relativement élevées. Une approche globale est nécessaire pour relever les défis de la productivité et de l'inclusion, en tirant parti de leurs synergies. Le gouvernement a pris des mesures à cette fin, centrées autour du Nouveau Modèle Social, mais les efforts doivent se poursuivre. Les réformes devraient être axées sur la création d'un environnement encore plus propice aux entreprises en facilitant l'adoption de nouvelles réglementations sur l'emploi des travailleurs de pays tiers et en réduisant l'informalité. Les initiatives visant à améliorer la gouvernance des entreprises publiques sont les bienvenues et doivent se poursuivre. L'amélioration de l'accès au financement et la mise en place de procédures de faillite efficaces sont essentielles pour stimuler le dynamisme des entreprises, tout comme les mesures visant à encourager la collaboration avec le secteur de la recherche en matière d'innovation. Traiter les grandes disparités de compétences est également une priorité. Il est important d'accroître la pertinence du système éducatif pour le marché de l'emploi. Des emplois plus nombreux et de meilleure qualité dans le secteur formel, en particulier pour les personnes peu qualifiées, sont essentiels à l'inclusion et au bien-être, tandis que des 
programmes de soutien actifs et plus efficaces du marché du travail contribueraient à lutter contre la pauvreté.

Ce document de travail se rapporte à l'étude économique de l'OCDE de la Lituanie de 2018. (www.oecd.org/eco/surveys/economic-survey-ireland.htm)

Ce document de travail se rapporte à Classification JEL: D31, J24, I24, I30, J31, O31

Mots clés: Lituanie, prestations, inclusivité, inégalité, informalite, innovation, financement, productivité, pauvreté, éducation, inadéquation des compétences, législation de protection de l'emploi. 


\section{Table of contents}

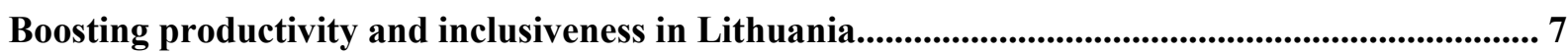

Convergence can be more sustainable and inclusive ....................................................................... 9

A coordinated policy response is needed to increase productivity and foster inclusiveness .............. 19

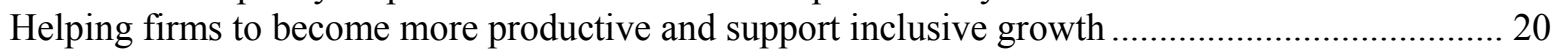

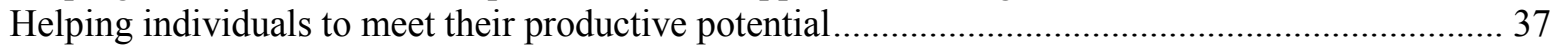

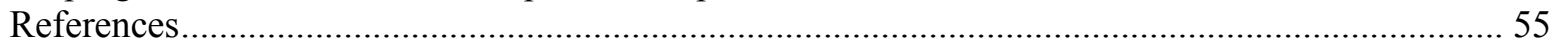

Annex A. Labour productivity growth: shift share analysis ................................................................. 58

\section{Figures}

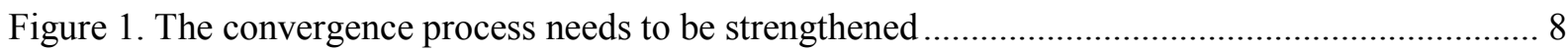

Figure 2. Low labour productivity explains most of the gap in incomes .......................................... 10

Figure 3. Total factor productivity and capital deepening weakened............................................... 10

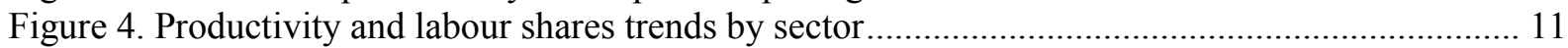

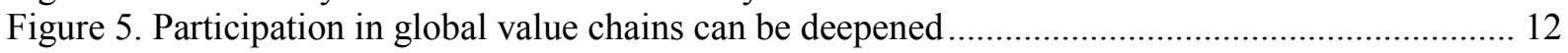

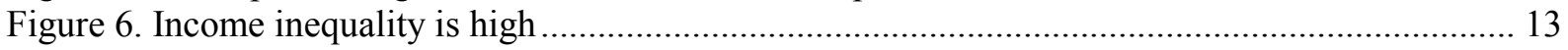

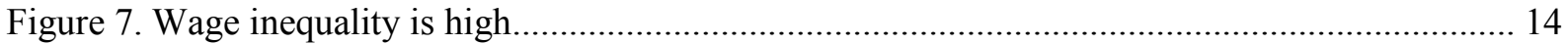

Figure 8. The tax and transfers system could be more effective in reducing inequality ...................... 14

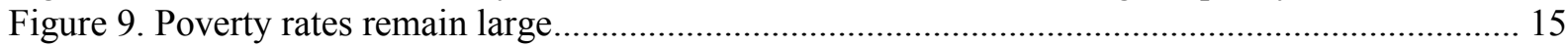

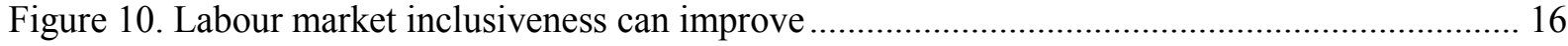

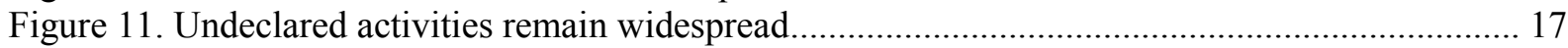

Figure 12. Earnings are low and low-pay widespread................................................................... 18

Figure 13. Lithuanian employees perceive their career prospects to be weak, 2015 .......................... 19

Figure 14. Income inequality is positively correlated with productivity disparities across sectors ...... 20

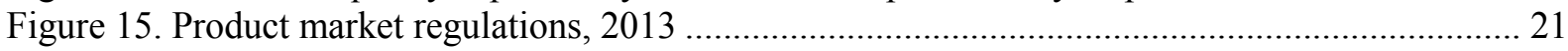

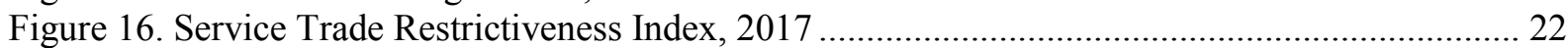

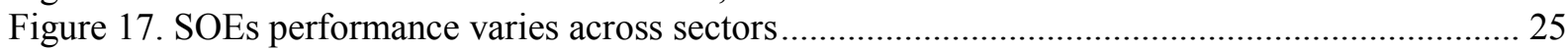

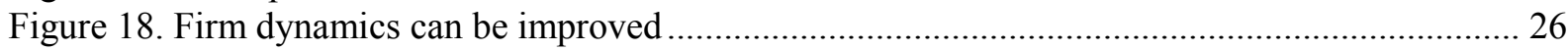

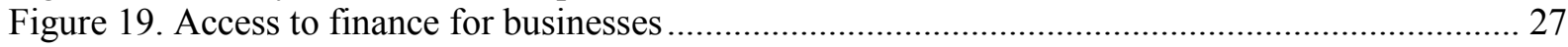

Figure 20. The insolvency framework can become more efficient ...................................................... 29

Figure 21. There is scope to catch up with more innovative countries ................................................ 30

Figure 22. Firm level innovation and absorptive capacity are low..................................................... 31

Figure 23. Business innovation is low despite generous tax incentives ............................................. 32

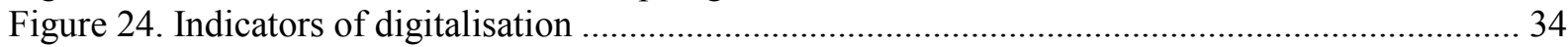

Figure 25. There is scope to increase collaborative research ........................................................... 35

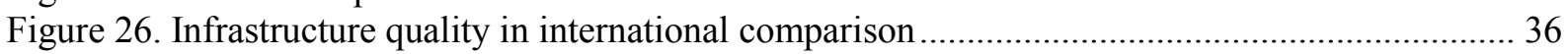

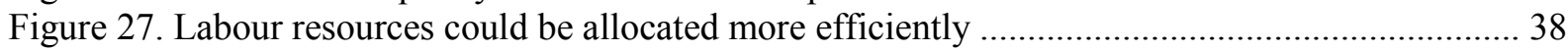

Figure 28. Lithuania has a highly educated workforce but the skill mix needs to improve .................. 39

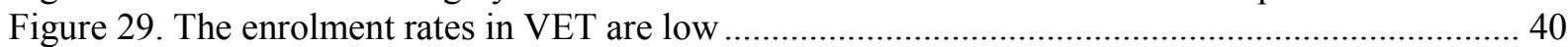

Figure 30. There is need to strengthen basic skills for the digital working environment..................... 41 


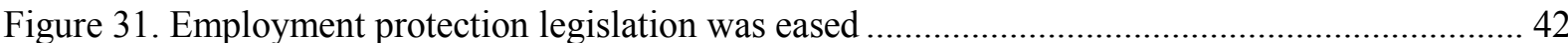

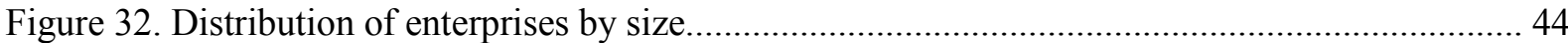

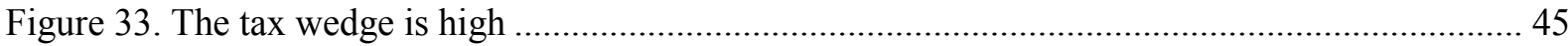

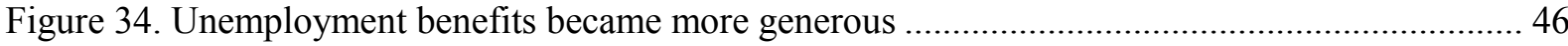

Figure 35. Receipt of social benefits increased but support remains weak ......................................... 47

Figure 36. Child income poverty rates are high, especially in jobless households ............................... 48

Figure 37. Financial incentives to take up a job are weaker for large households ............................... 51

Figure 38. Expenditure on active labour market programmes ............................................................. 53

\section{Boxes}

Box 1. Reforms in employment procedures for foreign workers: main provisions ............................ 24

Box 2. Social assistance and in-work benefits schemes: main features .............................................. 49

Box 3. Recommendations on raising productivity for inclusive growth ............................................ 54 


\title{
Boosting productivity and inclusiveness in Lithuania
}

\author{
By Vassiliki Koutsogeorgopoulou and Demetrio Guzzardi ${ }^{1}$
}

The productivity catch-up with the OECD average has been impressive over the past two decades (Figure 1). Nonetheless, the gap remains large. Productivity growth decelerated after the financial crisis, and this deceleration is broad-based, affecting most sectors of the economy. This has implications for inclusiveness: the convergence process has slowed down and income remains at around one-third below the OECD average. Income inequality and poverty remain high and income disparities have increased in recent years (Figure 1). Low productivity reflects some remaining barriers to investment, relatively weak firm dynamics, skills mismatch and large informality.

The government has undertaken many reforms in recent years to boost productivity and inclusive growth. These include measures to improve the business environment, encourage innovation, enhance skills, modernise labour relations, and strengthen income support. In addition, the National Productivity Board was established at end-2017 to monitor productivity developments and potential risks and evaluate proposals for reforms. However, more needs to be done to ensure higher living standards for Lithuanians and prepare for the future in an aging society.

\footnotetext{
${ }^{1}$ Vassiliki Koutsogeoropoulou is with the OECD Economics Department. Demetrio Guzzardi was an intern in the Economics Department at the time of the preparation of the Economic Survey and is now Research Assistant at the Paris School of Economics. The authors would like to thank Alvaro Pereira, Piritta Sorsa, Hansjoerg Bloechliger, Ben Westmore (OECD Economics Department), Korin Kane, Etienne Lepers (OECD Directorate for Financial and Enterprise Affairs), Sebastian Königs, Ann Vourc'h (OECD Directorate for Employment, Labour and Social Affairs) and colleagues from other Departments of OECD and experts from the Lithuanian Government for their valuable comments and feedback. Special thanks go to Hermes Morgavi for research assistance and Carolina Gonzalez for editorial assistance (OECD Economic Department).
} 
Figure 1. The convergence process needs to be strengthened
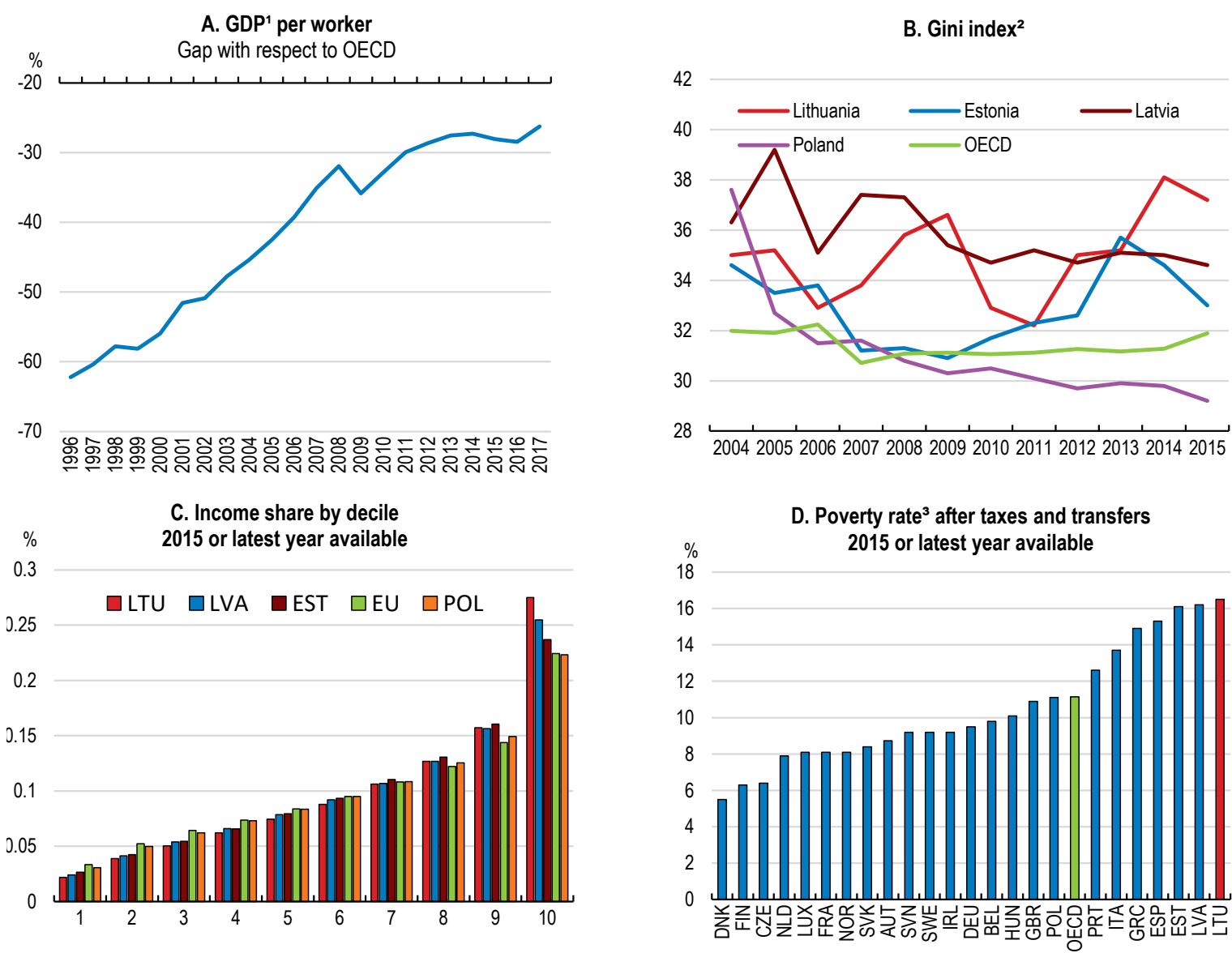

1. GDP in 2010 USD PPP. The rate of convergence is the annual difference in labour productivity gap.

2. Calculated on the basis of disposable income after taxes and transfers.

3. The poverty rate is the ratio of the number of people (in a given age group) whose income falls below the poverty line, set as half the median household income of the total population.

Source: OECD Productivity database; and OECD Income Distribution and Poverty database.

StatLink ज्ञाज https://doi.org/10.1787/888933788966

This paper examines policies that can help reinvigorate productivity growth and foster inclusiveness, building on the synergies between these two challenges. The next section explains the productivity slowdown and the reasons behind the relatively high inequality and poverty rates, with a special focus on labour market inclusiveness. Section three discusses the productivity-inclusiveness nexus, in particular the link between productivity dispersion and wage inequality. Section four considers the policies that can help firms to become more productive and support inclusive growth, in particular the challenge to make them more dynamic and innovative. Section five addresses measures that aim to ensure that individuals, especially the most vulnerable ones, have the opportunities and the skills for more and better jobs, while providing efficient support to the jobless and poor. 


\section{Convergence can be more sustainable and inclusive}

\section{Productivity growth has slowed from its pre-crisis highs}

Differences in labour productivity explain most of the gap in living standards between Lithuania and OECD average (Figure 2, Panel A). After having increased annually by around $7 \%$ between 1996 and 2007 - approximately three and a half times faster than the OECD average - labour productivity growth more than halved over the following years, even if some recent pick up is taken into account (Figure 2, Panel B). Total factor productivity (TFP) growth - accounting for most of the labour productivity growth over the period 1996-2007 on average - has decelerated considerably since the crisis, indicating a less efficient use of inputs (Figure 3, Panel A). Strong investment and capital deepening in the run-up to the crisis created positive spillovers to the economy as a whole that lifted TFP growth. Since then, TFP growth has lost momentum, together with capital deepening, weakening the economy's growth potential. Investment plunged during the financial crisis, reflecting weak domestic demand and lower capital inflows. While growth resumed, the total investment rate, and importantly in the business sector, remains well below the precrisis peaks (Figure 3, Panels B and C). Low business confidence may be part of the explanation, but other factors (discussed below) including some remaining barriers to investment, skills mismatch and large informality, can also deter investment. The gap visà-vis the OECD average with regard to both TFP and capital deepening stood at over 16\% in 2017.

More in depth analysis based on sectoral data for the period 1997-2016 ("shift-share" analysis, Annex A) suggests that the deceleration of labour productivity growth in recent years was driven mainly by efficiency losses within each sector ("within effect"), reinforced by a considerable slowdown in the shift of workers from less to more productive sectors ("shift-effect"). Overall, sectors with above-average labour productivity level hardly increased their employment between 2007 and 2016, against total employment gains of around 7\% before the 2008 crisis (Figure 4). Most of the increase in the labour share, after the crisis, came from the least productive industries such as professional and administrative services, and entertainment and recreation. The movements of workers between sectors reflects both cyclical factors such as a weakening of domestic demand and a slow recovery in global trade after the crisis, and more structural ones related to the sectoral transformation of the Lithuanian economy towards more skill-intensive sectors, in particular services. 
Figure 2. Low labour productivity explains most of the gap in incomes
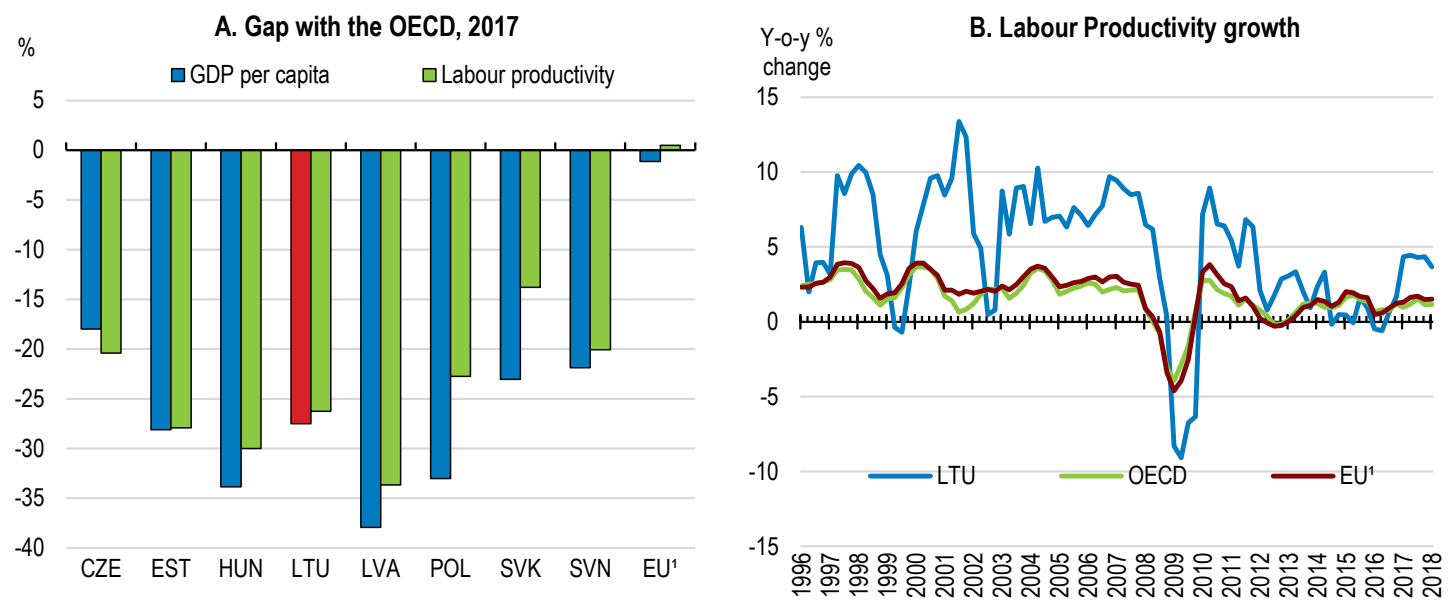

1. Data refer to the European countries that are OECD members.

Source: OECD Economic Outlook database.

StatLink त्माज् http://dx.doi.org/10.1787/888933788985

Figure 3. Total factor productivity and capital deepening weakened

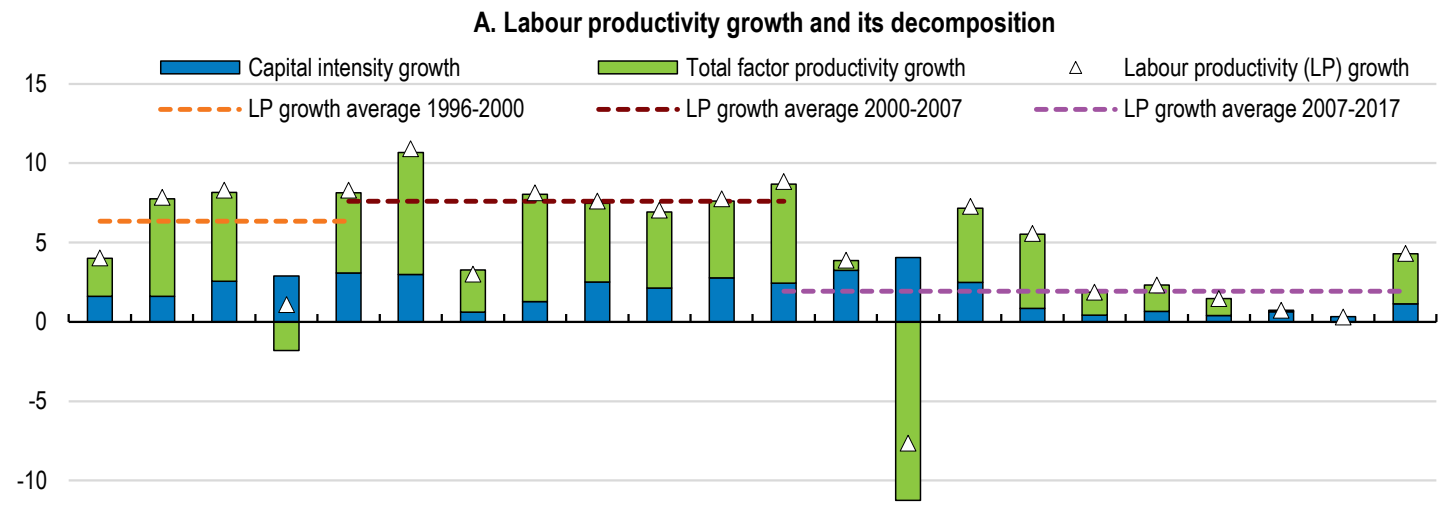

$-15$

1996199719981999200020012002200320042005200620072008200920102011201220132014201520162017

B. Investment rate

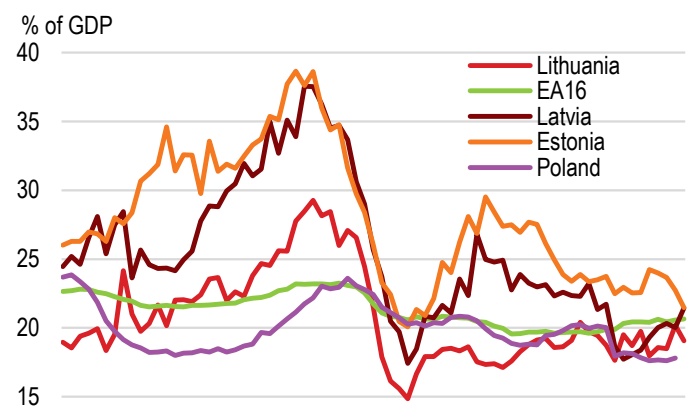

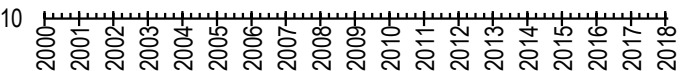

C. Investment composition

$\%$ of GDP

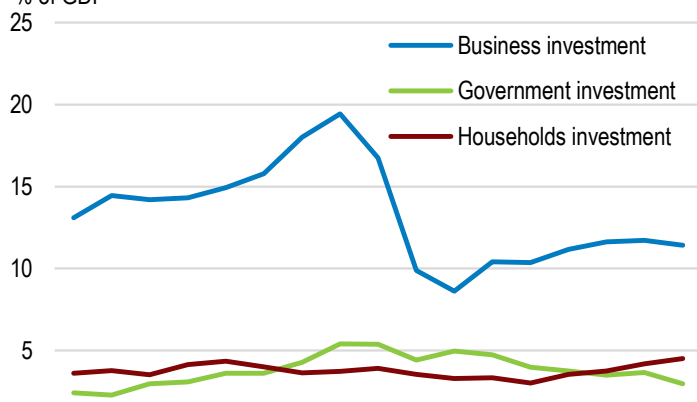

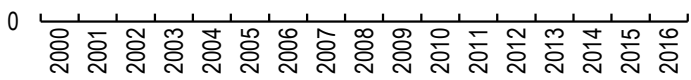

Source: OECD Economic Outlook database; Eurostat and OECD calculations.

StatLink त्राजग https://doi.org/10.1787/888933789004 
A major factor to boost productivity is a more successful participation in global value chains (GVCs), which is currently low (Figure 5, Panel A). Deepening integration in GVCs can benefit productivity as it enables knowledge transfer and provides access to more differentiated and better quality inputs (OECD, 2013). Foreign direct investment (FDI) is another important source of productivity gains as it tends to bring latest technologies and know-how to the country (OECD, 2016a). Recent trends in FDI are encouraging, but the inward FDI stock remains lower than in other Baltic countries in relation to GDP (Figure 5, Panels B and C). This may be explained in part by the fact that over the period 1990-1995 (first phase of privatisation after independence) the ownership of the majority of stateowned-enterprises in Lithuania were transferred to domestic residents, rather than strategic investors, as was the case for example in Estonia. Moreover, many projects in recent years concerned shared services centres, which do not require heavy capital expenditure and hence do not contribute much to FDI stock. However, other factors mentioned earlier, such as some remaining barriers to investment and the difficulties faced by firms in finding adequately-skilled workers, as well as the weak dynamism of the innovation system can also impact FDI decisions.

\section{Figure 4. Productivity and labour shares trends by sector}
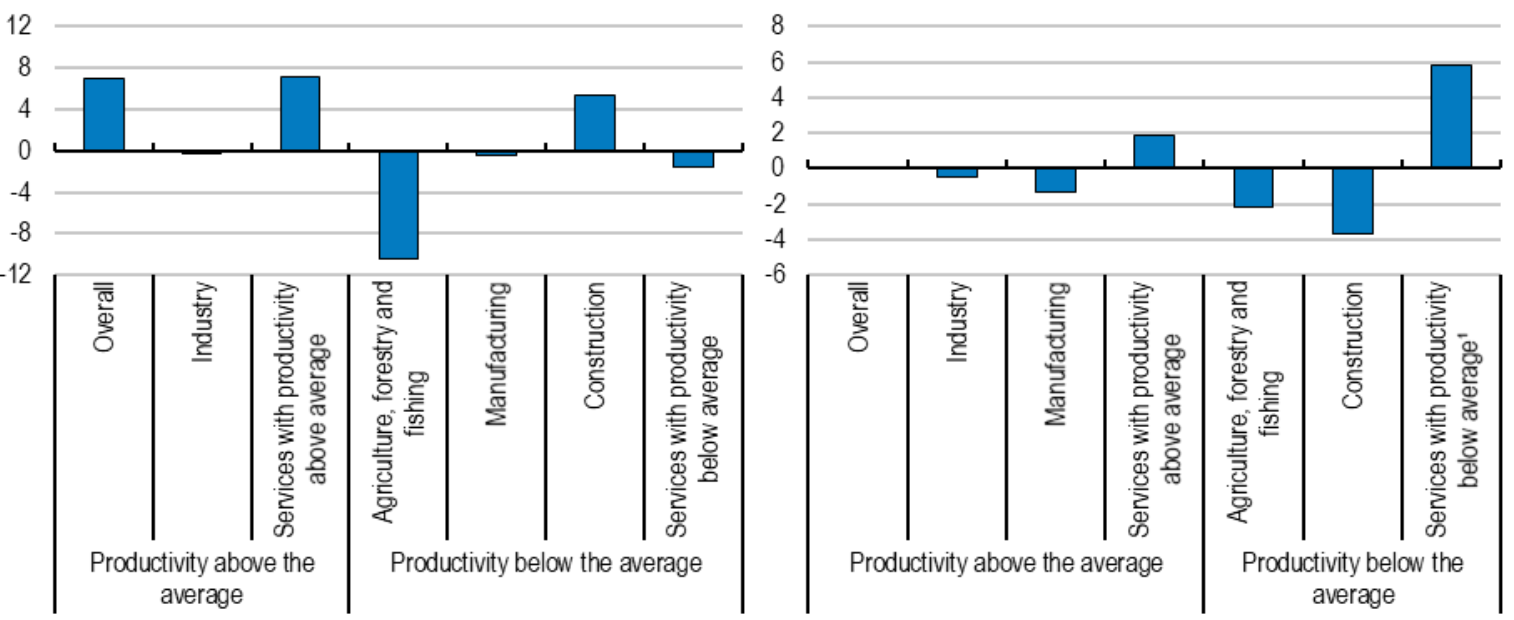

1. These include: Professional, scientific and technical activities, administrative and support service activities; Public administration, defence, education, human health and social work activities; and Arts, entertainment and recreation, repair of household goods and other services. Source: Eurostat; and OECD calculations. 
Figure 5. Participation in global value chains can be deepened

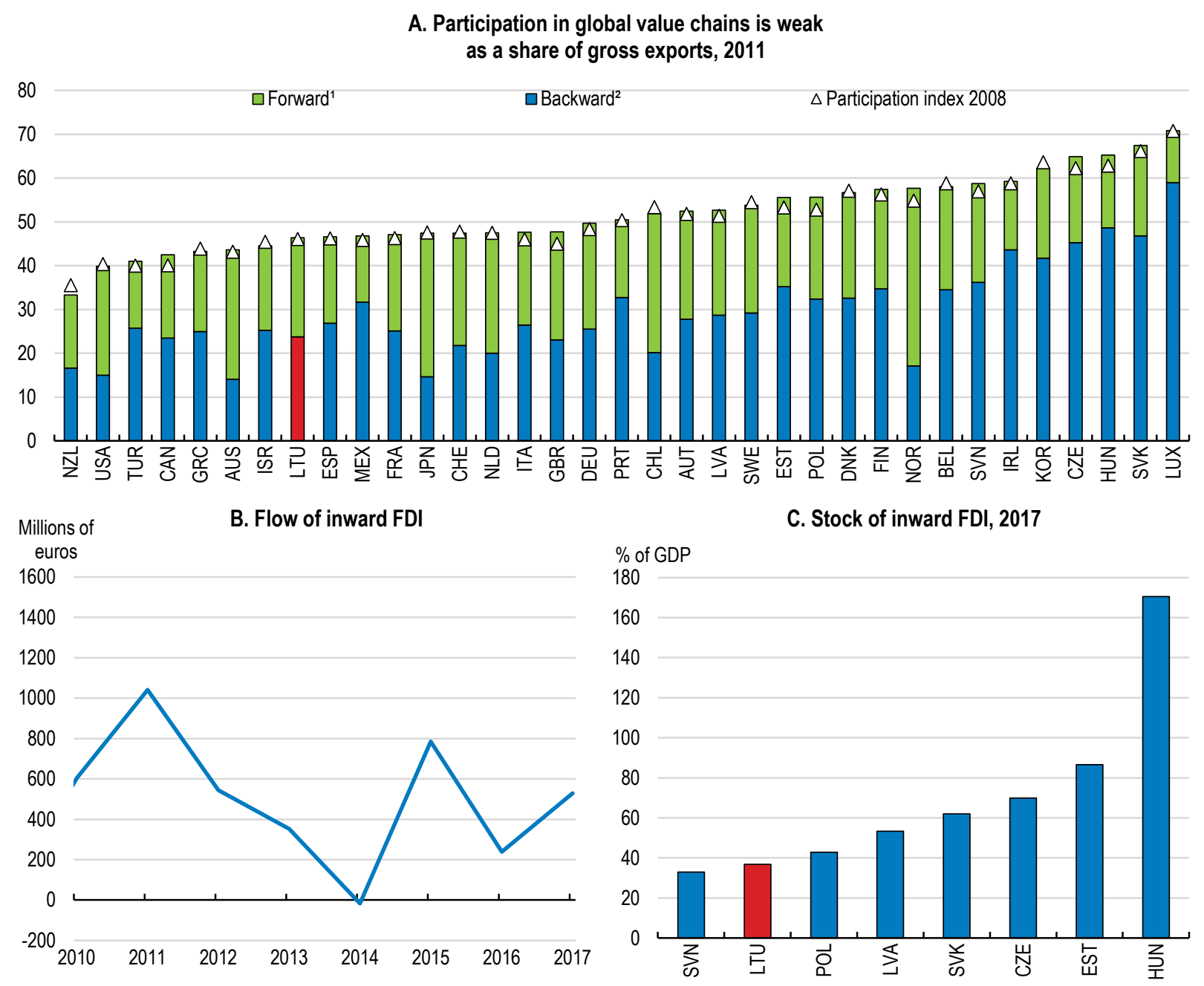

1. The indicator provides the share of exported goods and services used as imported inputs to produce other countries' exports. This indicator gives an indication of the contribution of domestically produced intermediates to exports in third countries.

2. The indicator measures the value of imported inputs in the overall exports of a country (the remainder being the domestic content of exports). This indicator provides an indication of the contribution of foreign industries to the exports of a country by looking at the foreign value added embodied in the gross exports.

Source: OECD International Trade database; World Bank World Development Indicators database; Bank of Lithuania; and IMF Balance of Payment database.

StatLink त्राs https://doi.org/10.1787/888933789042

\section{Inequality and poverty remain high}

Income disparities measured by the Gini index are among the largest in OECD and have increased in recent years, despite some improvement (Figure 1, Panel B and Figure 6, Panel A). Inequality is driven by the top and bottom ends of the income distribution, with earnings in the top decile at around 13 times higher than the bottom decile (Figure 6, Panel B). Moreover, the bottom 50\% of Lithuania's population has lost income share between 2004 and 2014, while the richest top $10 \%$ gained an additional $2.5 \%$. Recent analysis concludes 
that Lithuania's income inequality is high even after controlling for its level of economic development (IMF, 2016).

Figure 6. Income inequality is high

A. Gini index after taxes and tranfers, 2015 or latest year vailable

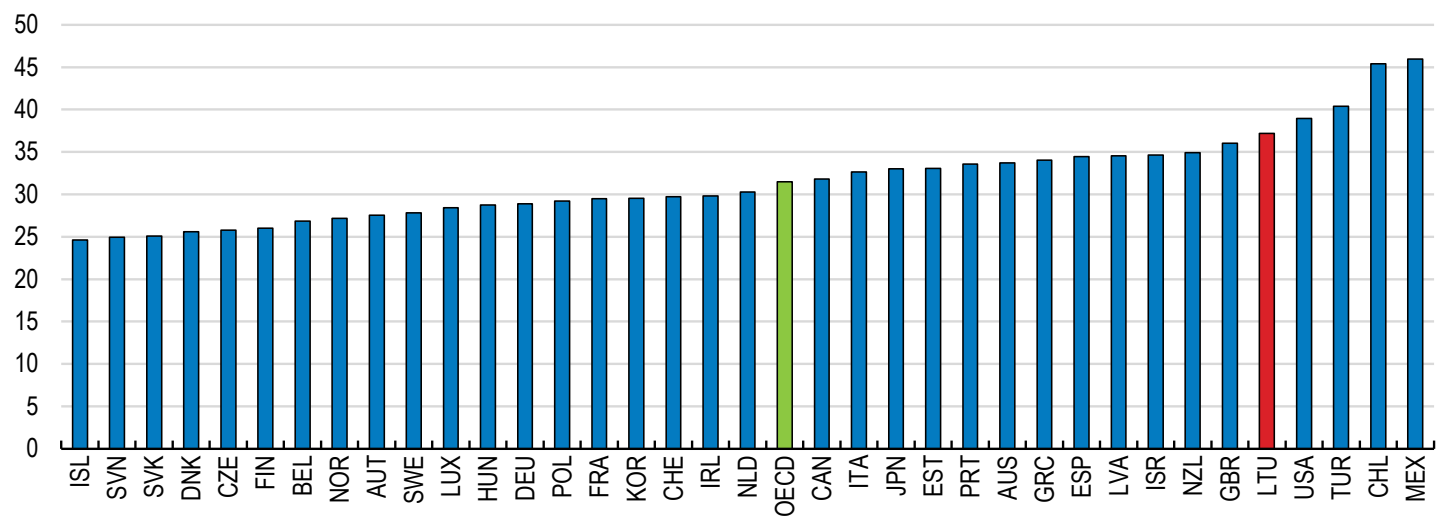

B. Ratio between income share of top decile and bottom decile, 2015 or latest year vailable

25

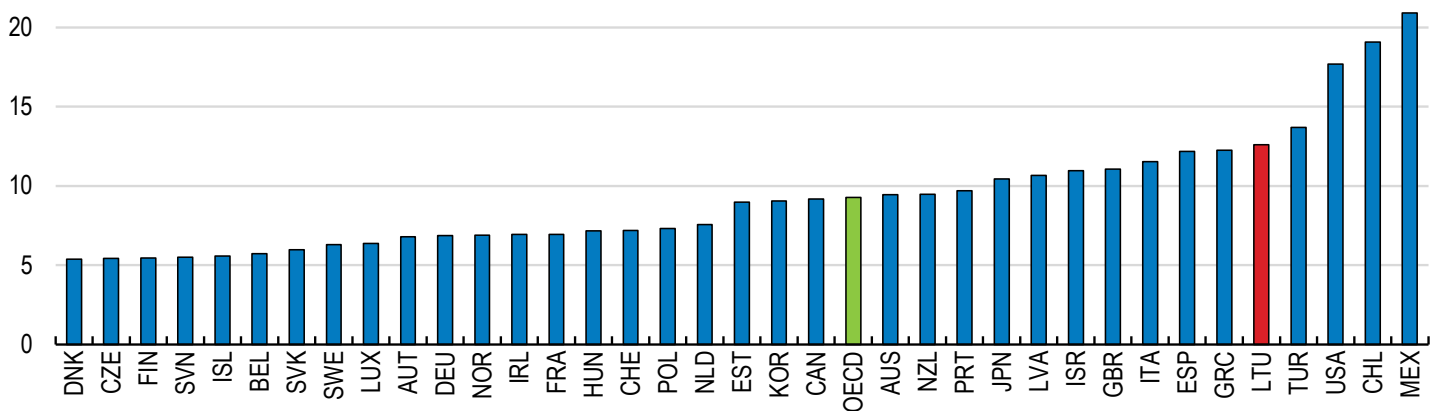

Source: OECD Income Distribution and Poverty database.

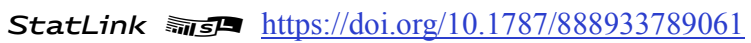

Large earnings dispersion is one of the key drivers of persisting income inequality in Lithuania (Figure 7, Panel A). At the same time, the tax-transfer system is not very effective as social benefits are low and the tax system is not very redistributive, as shown in the 2018 OECD Reviews of Labour Market and Social Policies: Lithuania (OECD, 2018a) (Figure 8). Regional disparities in disposable income are also considerable. To tackle wage inequalities, minimum wages were increased by $64 \%$ between 2009 and 2016, bringing the ratio of minimum to the median wages even above the OECD average (Figure 7, Panel B). Further increases may risk reducing job market opportunities for the less qualified. 
Figure 7. Wage inequality is high

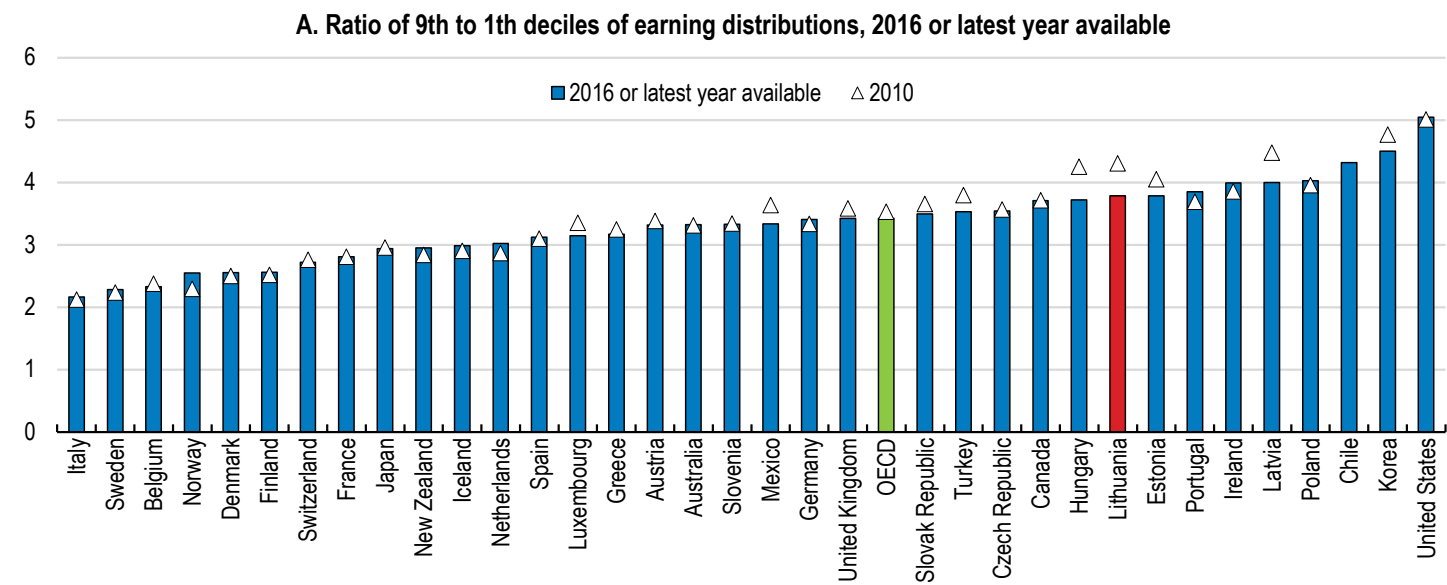

B. Minimum wage to median wage of full time workers, 2016

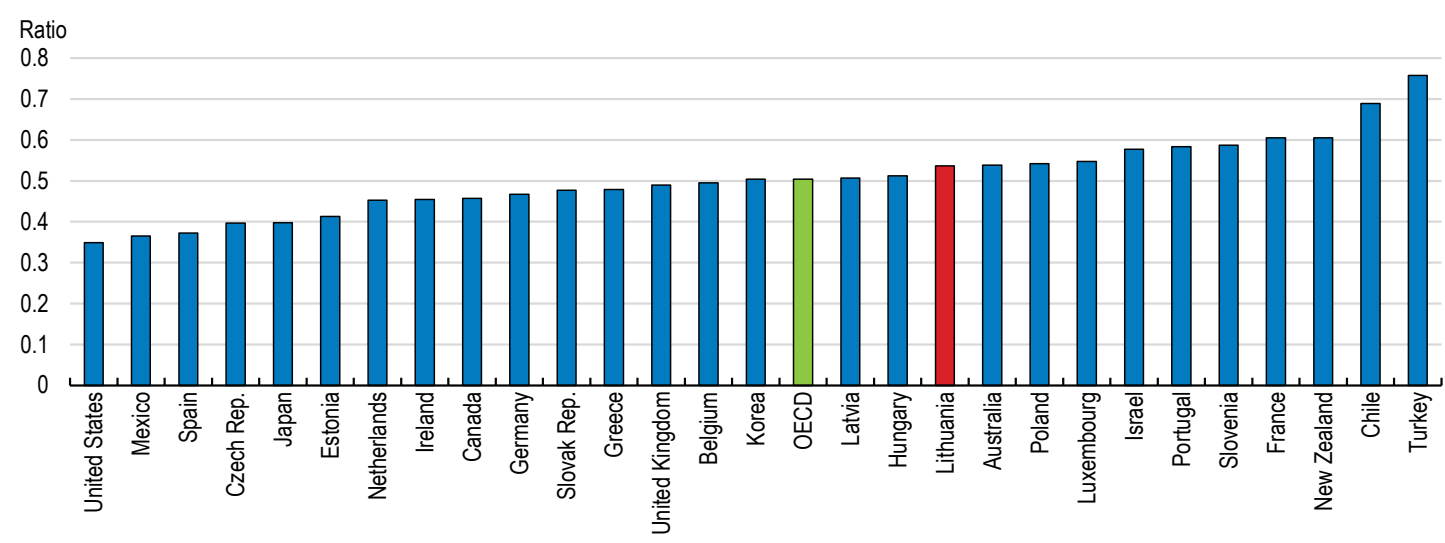

Source: OECD Labour database.

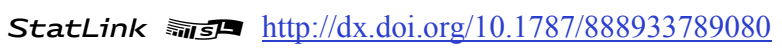

Figure 8. The tax and transfers system could be more effective in reducing inequality

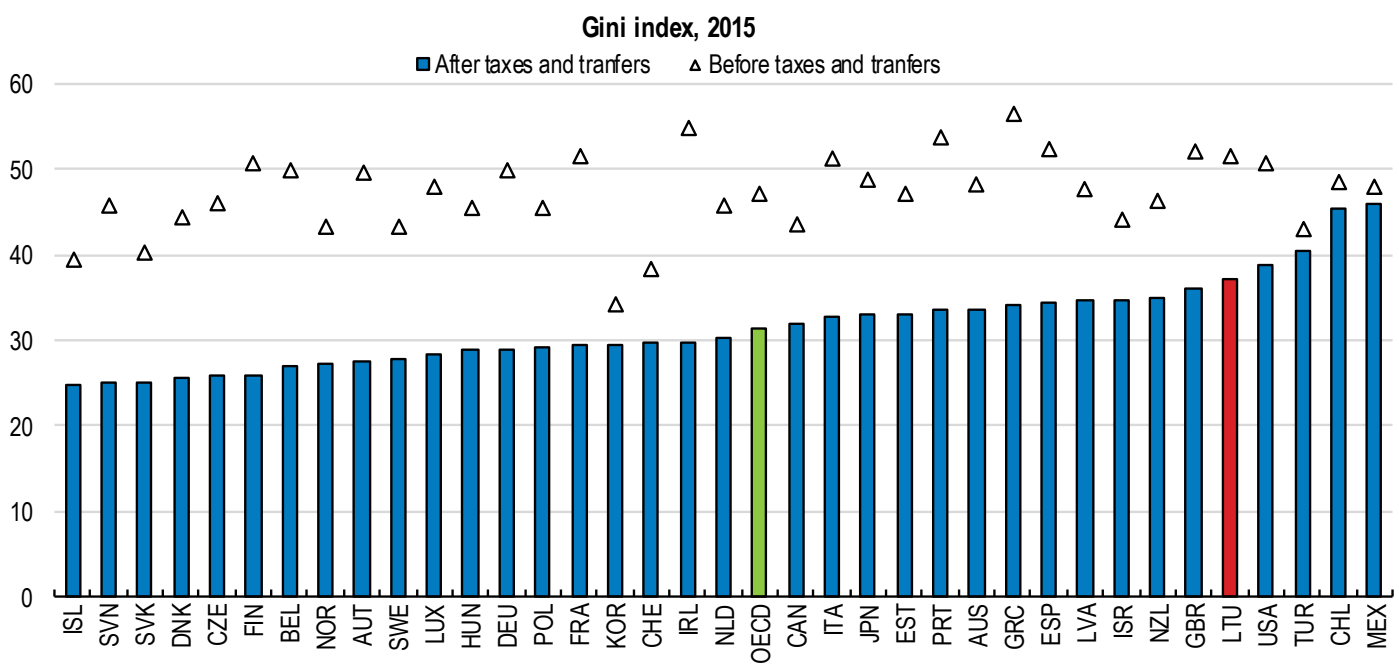

Source: OECD Income Distribution and Poverty database.

StatLink न्ताIst https://doi.org/10.1787/888933789099 
As a result, around $16.5 \%$ of Lithuania's population lives in relative poverty with an income below $50 \%$ of the median income, well above the OECD average of $11.1 \%$ although not very different from Estonia and Latvia (Figure 1, Panel D). Approximately 20\% of the population is estimated to have income that falls below the risk-of-poverty threshold (Figure 9). Women, the youngest and the elderly are particularly affected. As with other countries, the risk of poverty in Lithuania tends to fall with the level of education, with those who have not completed upper secondary education facing a very high risk.

Figure 9. Poverty rates remain large
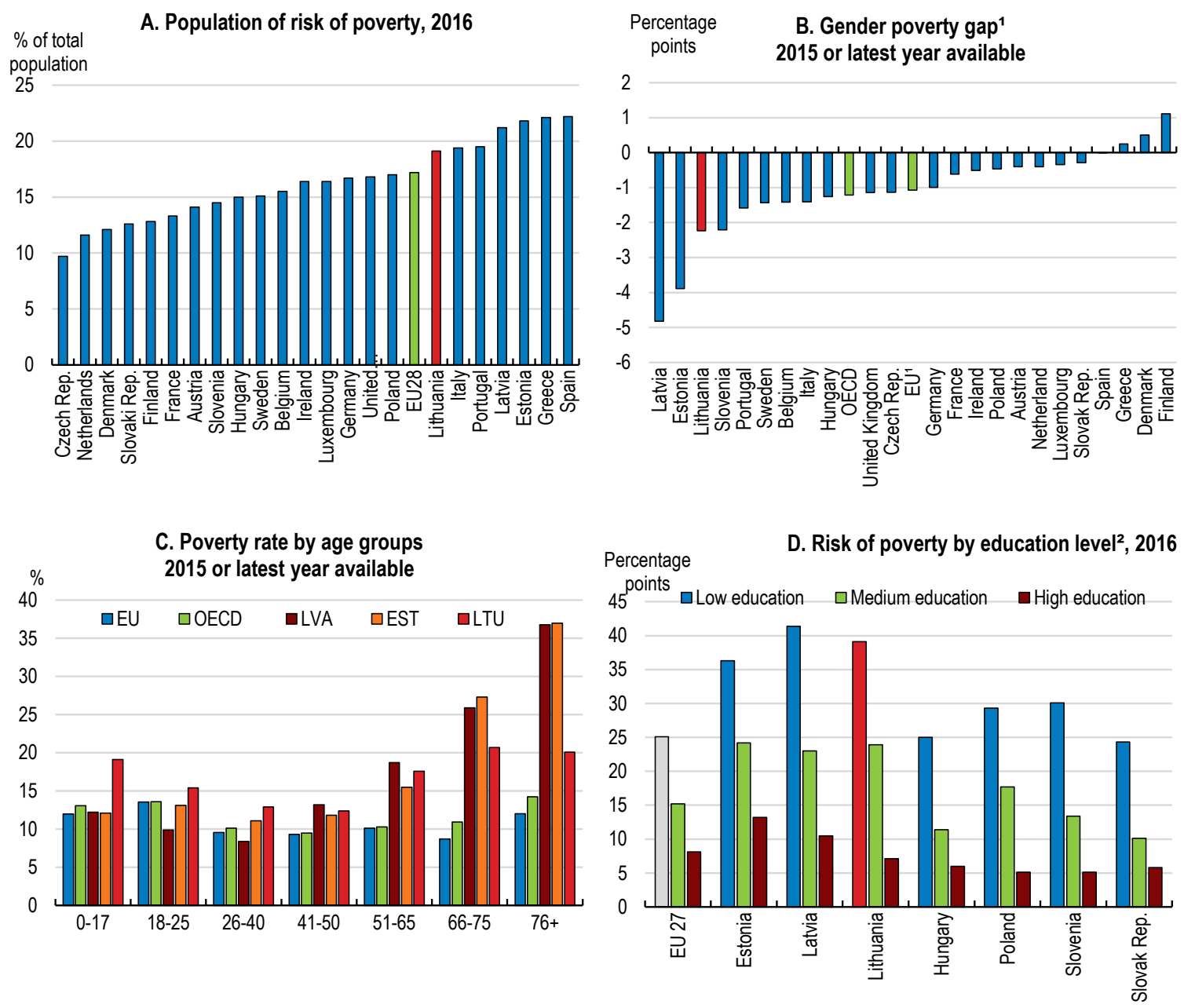

1. The poverty rate is the ratio of the number of people (in a given age group) whose income falls below the poverty line, set at half the median household income of the total population. The at-risk-of-poverty rate is the share of people with an equivalised disposable income (after social transfers) below the at-risk-of-poverty threshold, which is set at $60 \%$ of the national median equivalised disposable income after social transfers. 2. The gender poverty gap is defined as the poverty rate of men minus that of women.

3. The Low education category corresponds to individuals with less than primary, primary and lower secondary education; the Medium education category corresponds to individuals with upper secondary and post-secondary non-tertiary education; and the High education category corresponds to individuals with tertiary education. Source: Eurostat; and OECD Income Distribution and Poverty database. 


\section{The labour market is not very inclusive}

Poverty is closely related with labour market outcomes. Lithuania's labour market performed strongly since the start of the recovery, but unemployment still exceeds the OECD average, notably of the low-skilled (Figure 10). Regional differences in unemployment rates also remain large. Those who find themselves out of work face a particular high poverty risk in view of the low social benefits.

Figure 10. Labour market inclusiveness can improve
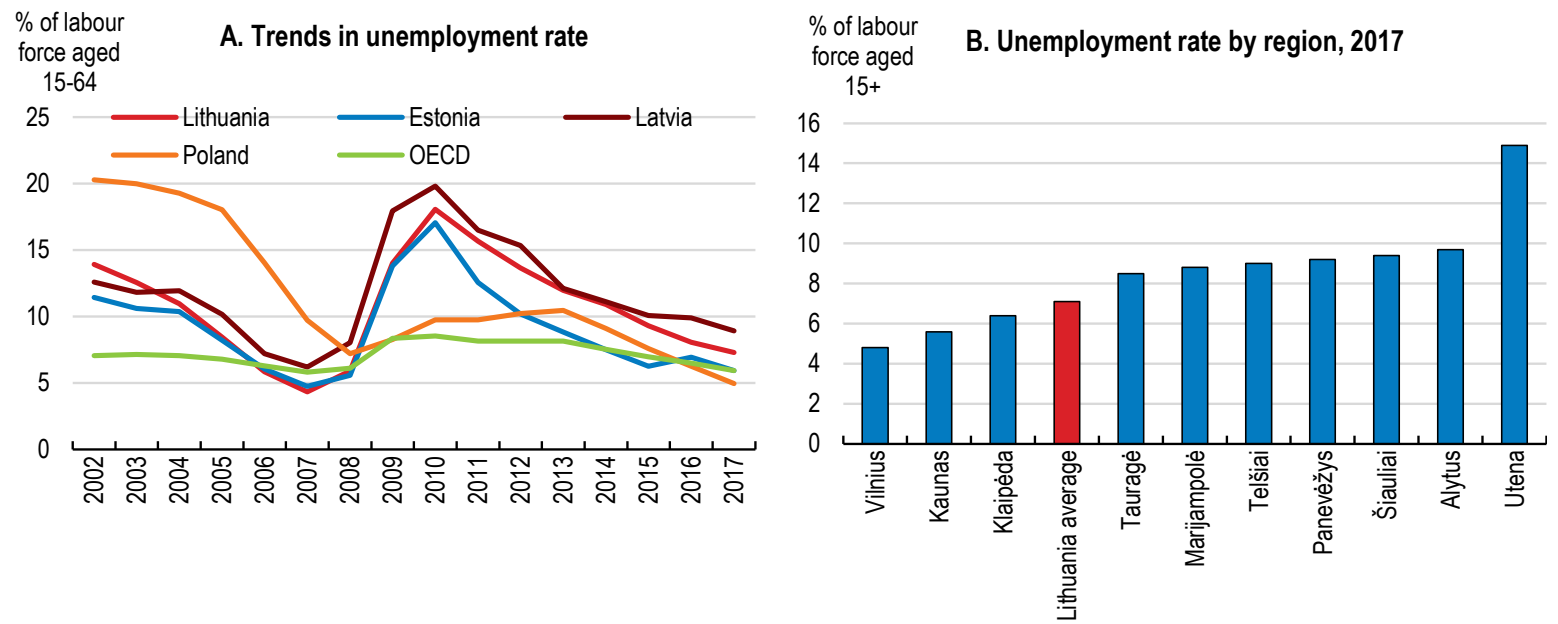

C. Group-specific unemployment rates, 2017

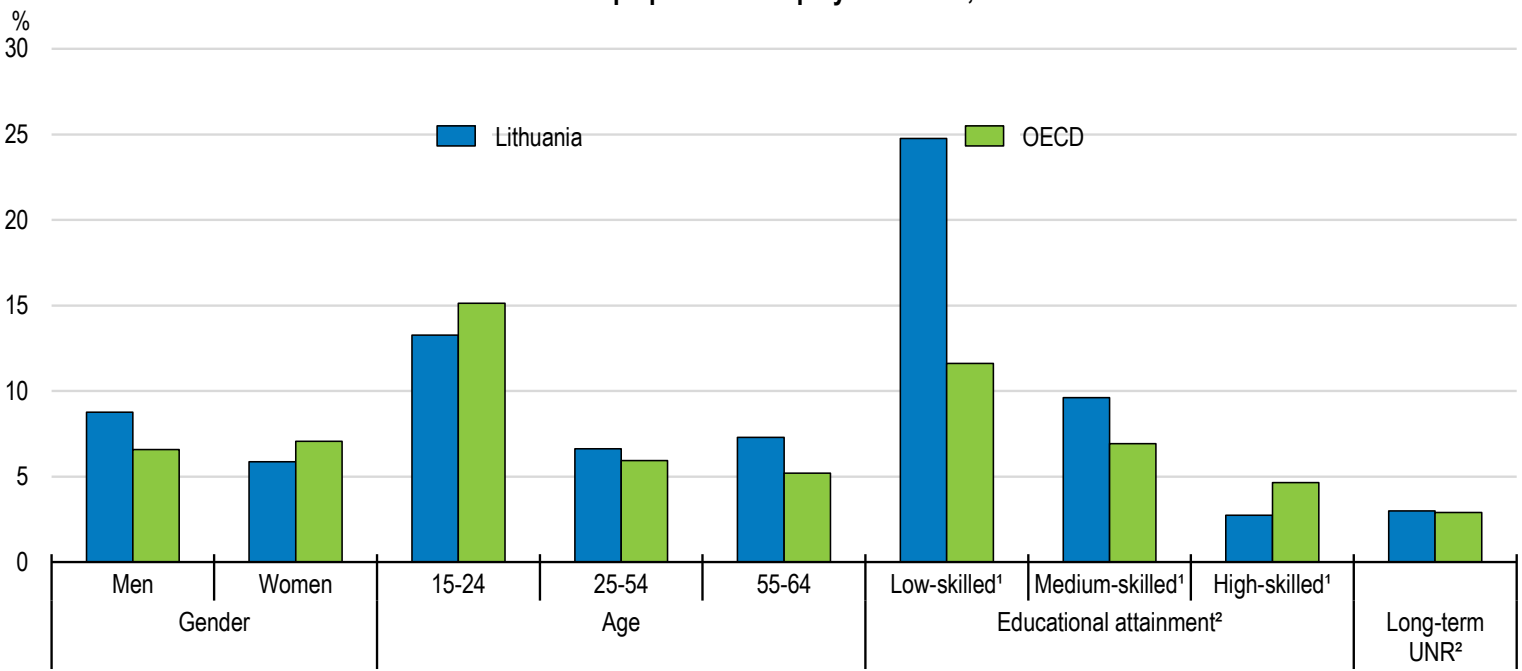

1. Calculated on the labour force aged 25-64.

2. Data refer to 2016.

Source: Statistics Lithuania; OECD Gender employment database; Eurostat; and OECD Education attainment and outcomes database.

StatLink त्ञाज https://doi.org/10.1787/888933789137

Another core factor affecting poverty and income distribution is the large size of the informal economy, estimated by various studies (e.g. Schneider, 2016, Figure 11, Panel A) at around $17 \%$ to $25 \%$ of GDP. The share of workers undertaking undeclared work is lower than in Latvia and Estonia, according to the 2013 Eurobarometer, but still well above the 
EU average (European Commission, 2014) (Figure 11). Many workers receive part of their wages as "envelope wages" (cash-in-hand, non-declared wages), avoiding taxation and social contributions. Undeclared self-employment is also a widespread form of informal employment and more common than in other Baltic countries (Žukauskas, 2015). High social security contributions and a perceived lack of regular jobs are among the explanations for informality (European Commission, 2014).

Figure 11. Undeclared activities remain widespread

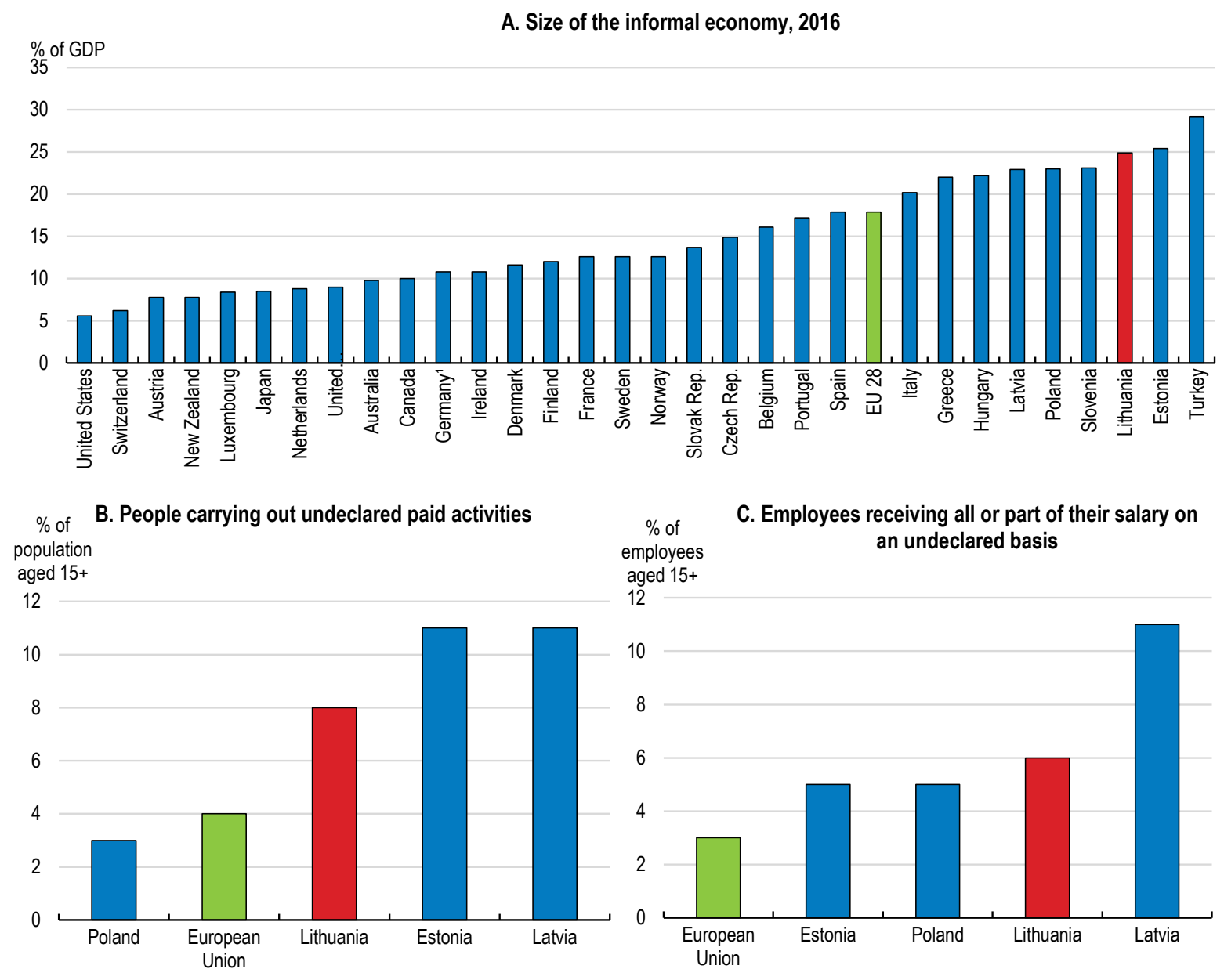

Source: Special Eurobarometer 402 (Fieldwork April May 2013); and Schneider, Friedrich (2016) : Estimating the Size of the Shadow Economies of Highly-developed Countries: Selected New Results, CESifo DICE Report, ISSN 1613-6373, Vol. 14, Iss. 4, pp. 44-53.

StatLink तiाs ht htps://doi.org/10.1787/888933789156

Informal work can have an adverse impact on job security and pay, especially for fully undeclared workers. They lack social security coverage and the protection provided by formal labour contracts, for instance with respect to the minimum wage, employment protection and occupational health and safety standards (OECD, 2018a). Informality also reduces incentives to invest in skill upgrading, as workers in the informal labour market have limited (if any) training and career advancement opportunities which are vital for earnings progression and a good quality job. Despite a decrease (by 0.7 percentage points) 
between 2010 and 2014, vulnerable employment accounted for around $10 \%$ of total employment (OECD, 2017a).

Low earnings remain a concern, as they also provide a strong incentive for emigration (see Chapter 2 of the 2018 Economic Survey of Lithuania). Despite moving closer to the OECD average, real wages are still low in international comparison at around $60 \%$ of the average in 2016 (Figure 12, Panel A). Almost a quarter of Lithuanian workers were low-paid in 2014 earning two-thirds or less of median earnings in 2014 (Figure 12, Panel B). While this share is much lower than the corresponding one in 2006, reflecting the hikes in minimum wages, it still compares unfavourably with an EU28 average of around $17 \%$. The incidence of low pay is particularly high among the less skilled, workers over 50 years, and in the construction and service industries such as real estate activities and accommodation.

Figure 12. Earnings are low and low-pay widespread

\section{A. Average earnings, 2016}

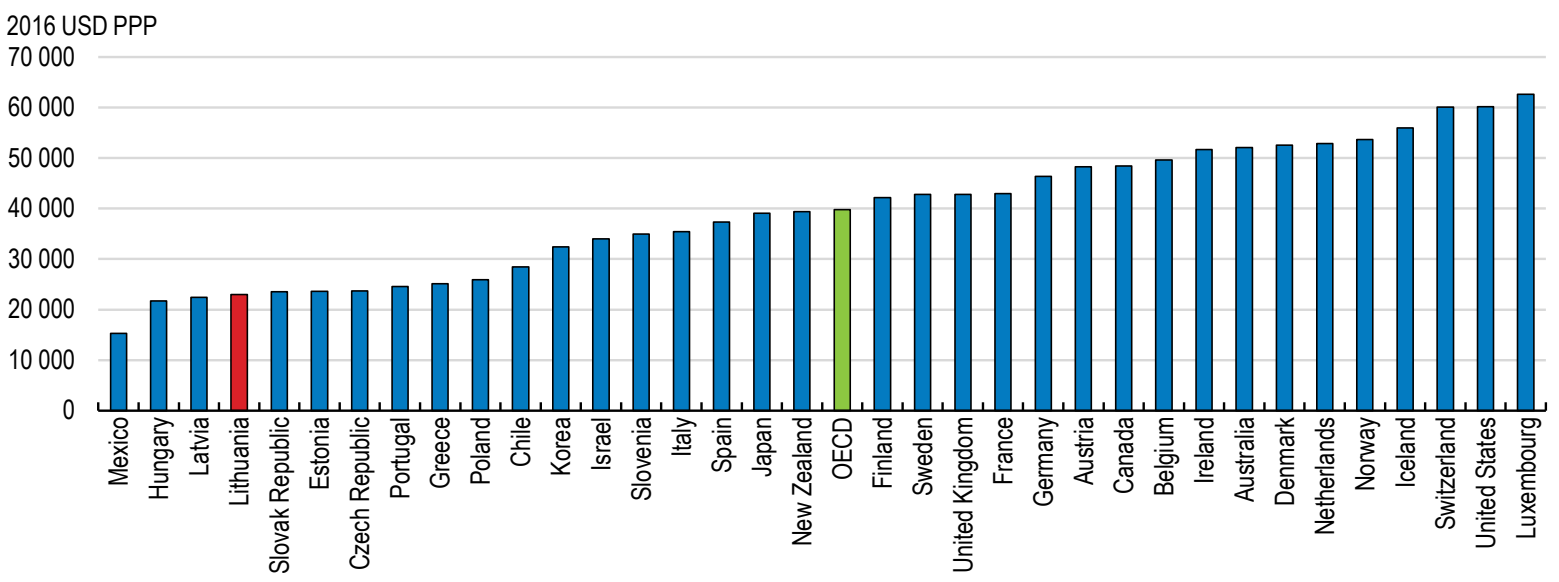

B. Low-wage earners' ${ }^{1}, 2014$

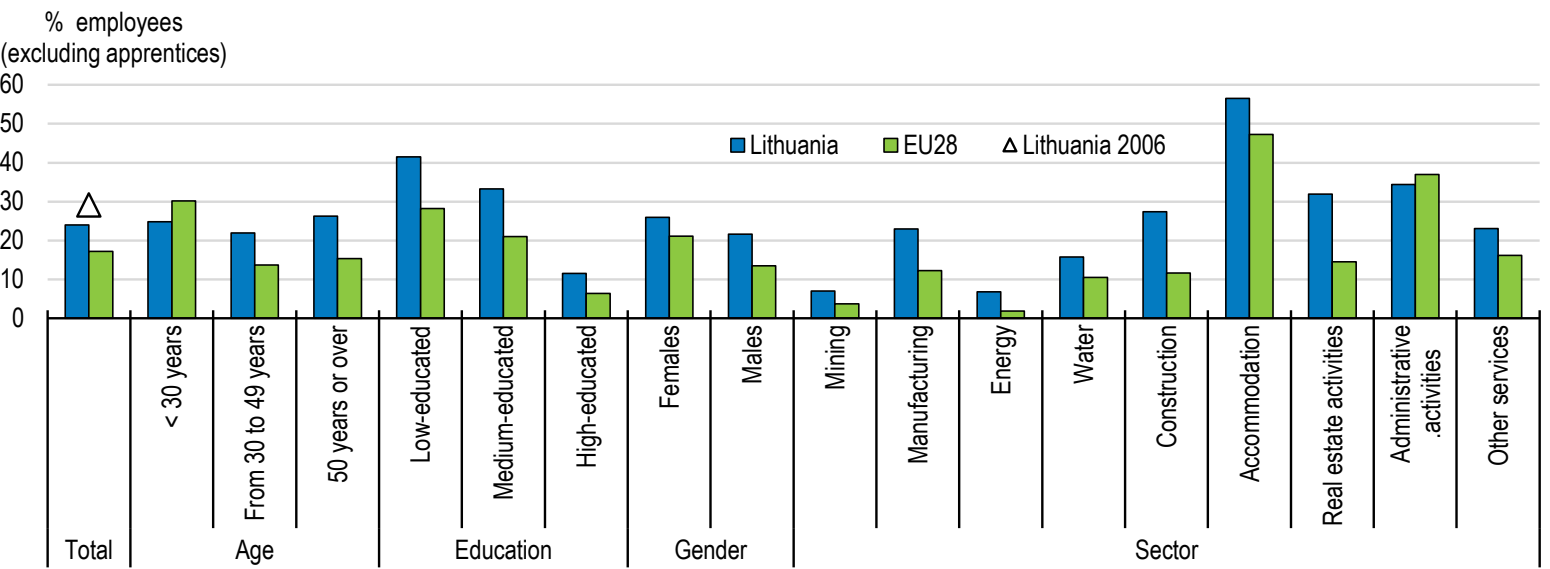

Note: Low-wage earners are defined as those employees earning two thirds or less of the national median gross hourly earnings.

Source: OECD labour database; and Eurostat 
Good working conditions are another acknowledged feature of a good quality job. Around $17 \%$ of Lithuanians are not satisfied with their working environment, according to a recent survey, somewhat above the EU28 average (Figure 13). However, the prospects for career progression are more of a concern among Lithuanian workers than on average in the EU and in other Baltic countries and Poland. In addition, $23 \%$ of Lithuanians would need more skills to cope well with their duties, compared to an EU average of 14\% (Eurofound, 2017).

Figure 13. Lithuanian employees perceive their career prospects to be weak, 2015

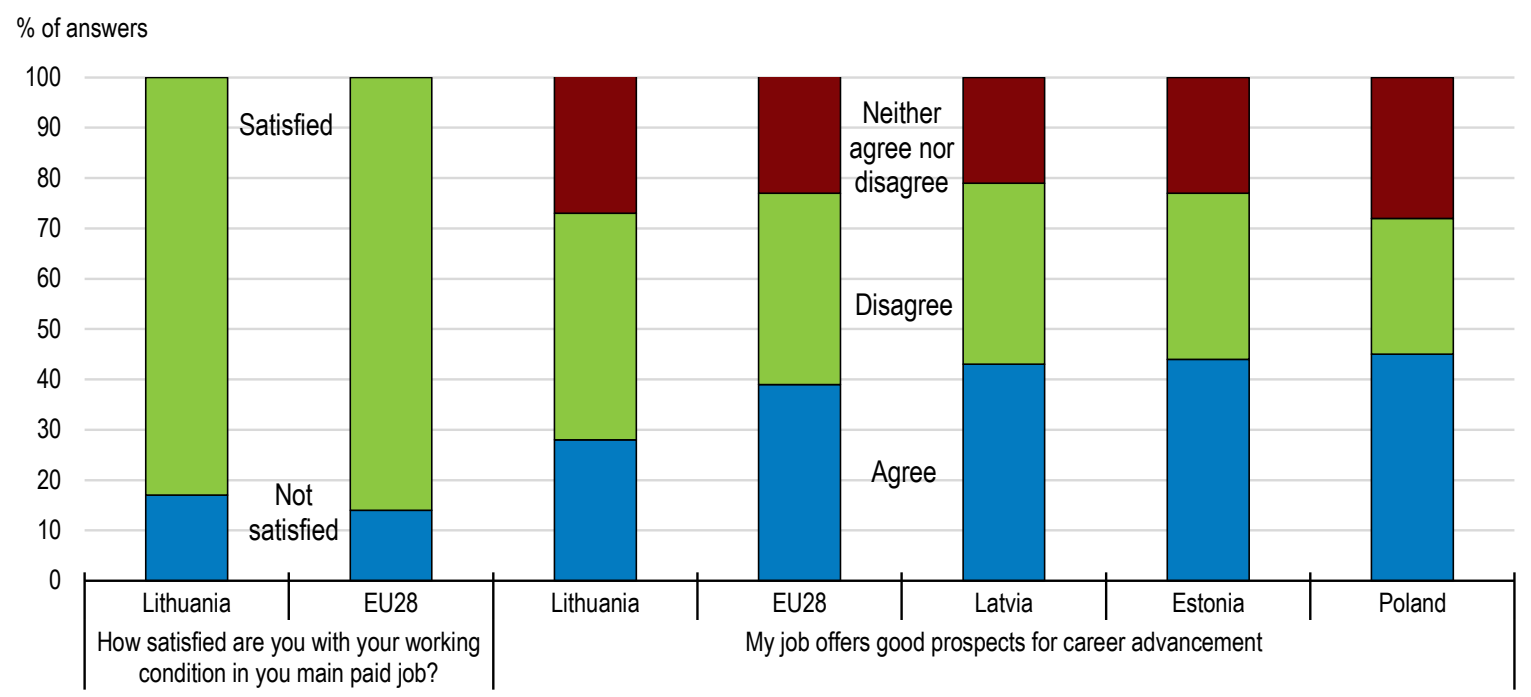

Source: Eurofound (2017), Sixth European Working Conditions Survey - Overview report (2017 update), Publications Office of the European Union, Luxembourg; and OECD calculations.

StatLink तiाs https://doi.org/10.1787/888933789194

\section{A coordinated policy response is needed to increase productivity and foster inclusiveness}

Promoting productivity and inclusiveness is a "twin challenge" (OECD, 2016b). Recent cross-country evidence suggests that much of the widening of the wage distribution over the past two or three decades can be attributed to increases in the variance of wages between firms, linked in turn to productivity dispersion across firms (Andrews et al., 2016). Firmlevel data were not available for Lithuania at the time of the preparation of the Survey. However, analysis based on sectoral data on the relationship between labour income inequality and productivity disparities suggests that Lithuania has a wider income and productivity gap than the OECD average (Figure 14). At the same time, high income inequality and poverty can undermine productivity and growth potential by reducing investment in human capital, in addition to being socially undesirable (OECD, 2016c).

Addressing the "twin challenge" of boosting productivity and fostering inclusiveness requires a broad-based and integrated approach to policy. Well-designed active labour market programmes, for example, could facilitate the reallocation of workers towards more productive sectors by helping displaced individuals to transition to new, good jobs (OECD, 2016b). Initiatives in education yield clearly a double dividend in terms of promoting productivity and inclusiveness. 
Figure 14. Income inequality is positively correlated with productivity disparities across sectors

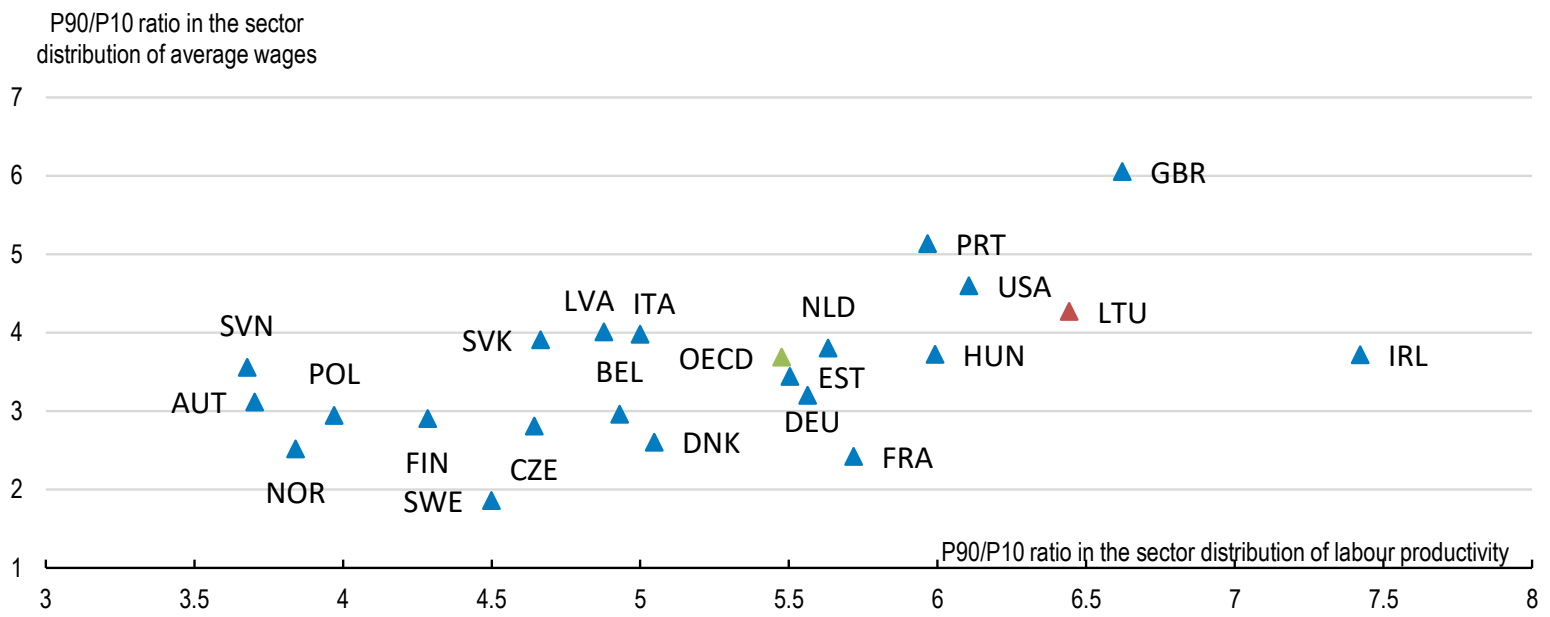

Source: OECD National Account database; and Lithuania Statistics.

StatLink त्माज http://dx.doi.org/10.1787/888933789213

The rest of the paper examines potential reforms that help both firms and individuals to meet their productive capacity, while ensuring a broader sharing of the productivity gains across society. Measures that reduce remaining barriers to investment and competition, encourage firm entry and exit, and foster innovation have an important role to play in this regard. Similarly, policy initiatives that address skill mismatches and provide opportunities for more and good quality jobs are key to greater productivity and inclusiveness, as are measures helping to combat poverty effectively. Reducing informality is also a win-win policy for productivity and inclusiveness, as formal firms tend to be more productive and to offer higher quality jobs.

\section{Helping firms to become more productive and support inclusive growth}

\section{Removing remaining barriers to investment}

Lithuania's regulatory environment is overall business friendly and open to foreign investment. Barriers to entrepreneurship are relatively low on the basis of the OECD Product Market Regulation (PMR) indicator (Figure 15). This is also echoed in the World Bank's Doing Business index, where Lithuania is placed among the top 20 countries (World Bank, 2018). Moreover, Lithuania ranks among the top 10 countries with the most open markets for services trade (OECD, 2018b). However, some barriers to investment, including relatively tight regulations for the employment of non-EU workers and for entering legal services, as well as restrictions for the acquisition of land by foreigners from some countries (Figure 15 and Figure 16), can reduce the country's attractiveness to foreign investors with current efforts to address such barriers going in the right direction. 
Figure 15. Product market regulations, 2013

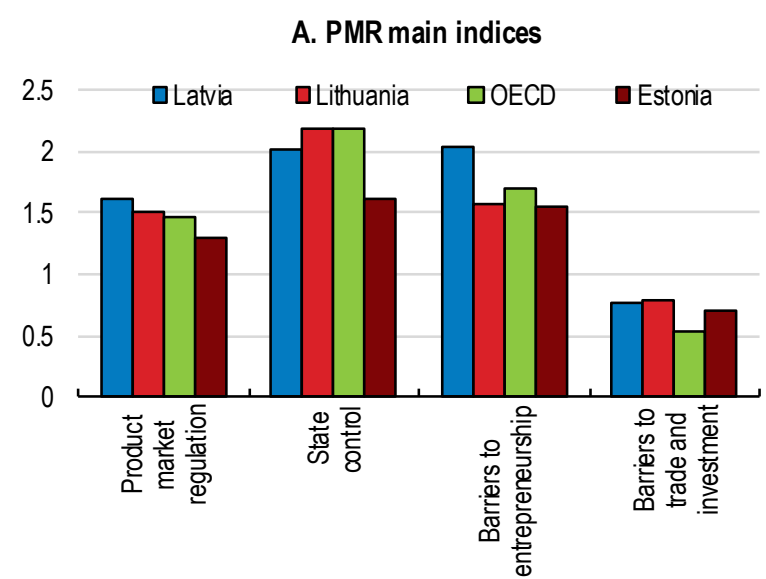

C. State Control

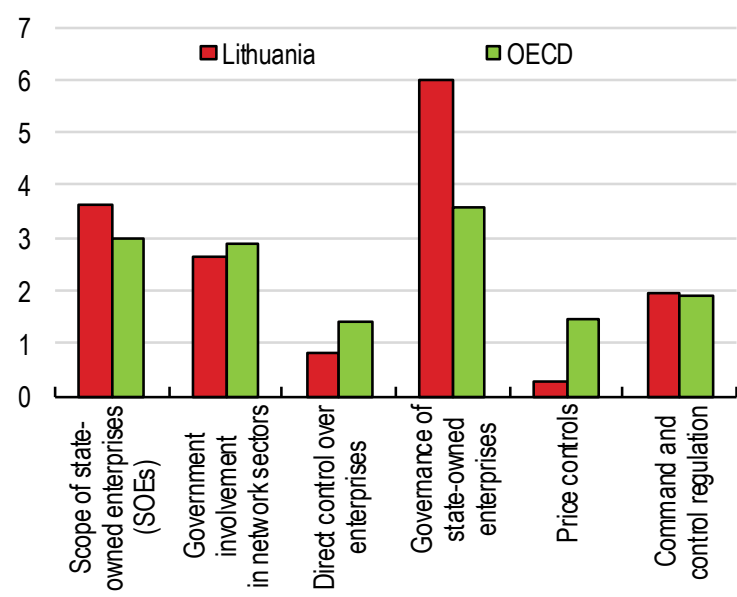

B. Barriers to entrepreneurship

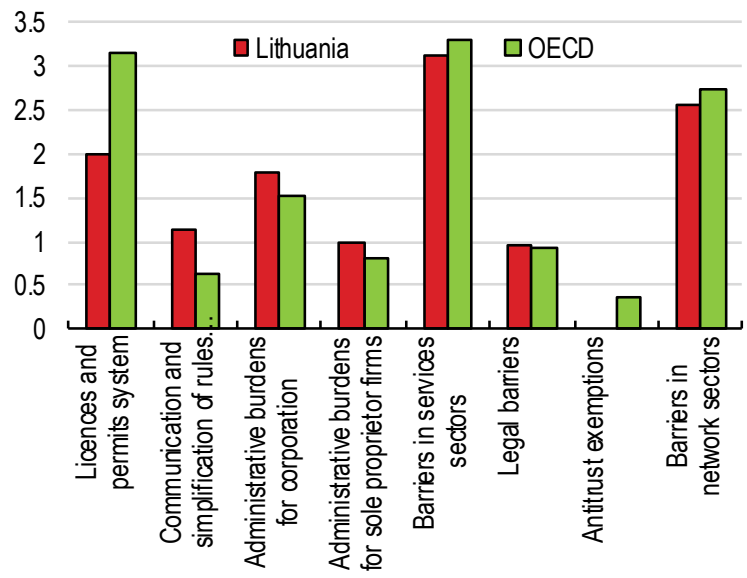

D. Barriers to trade and investment

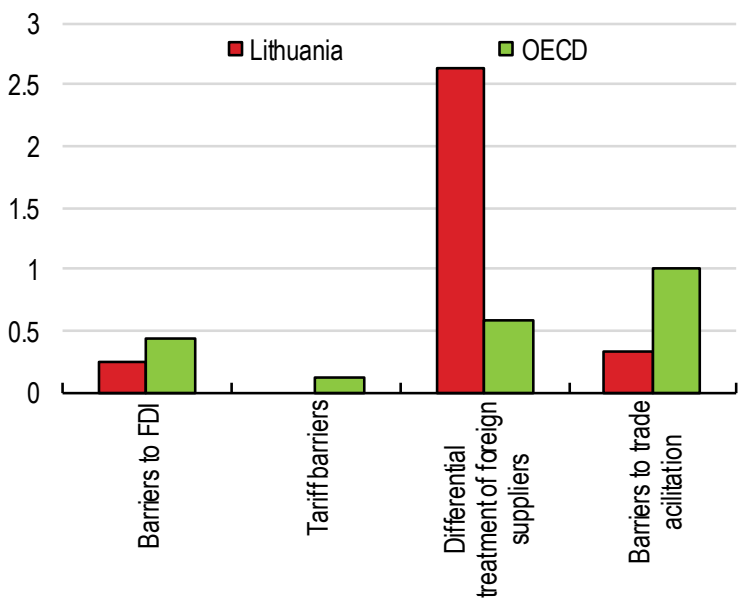

Source: OECD Product market regulation database. 
Figure 16. Service Trade Restrictiveness Index, 2017

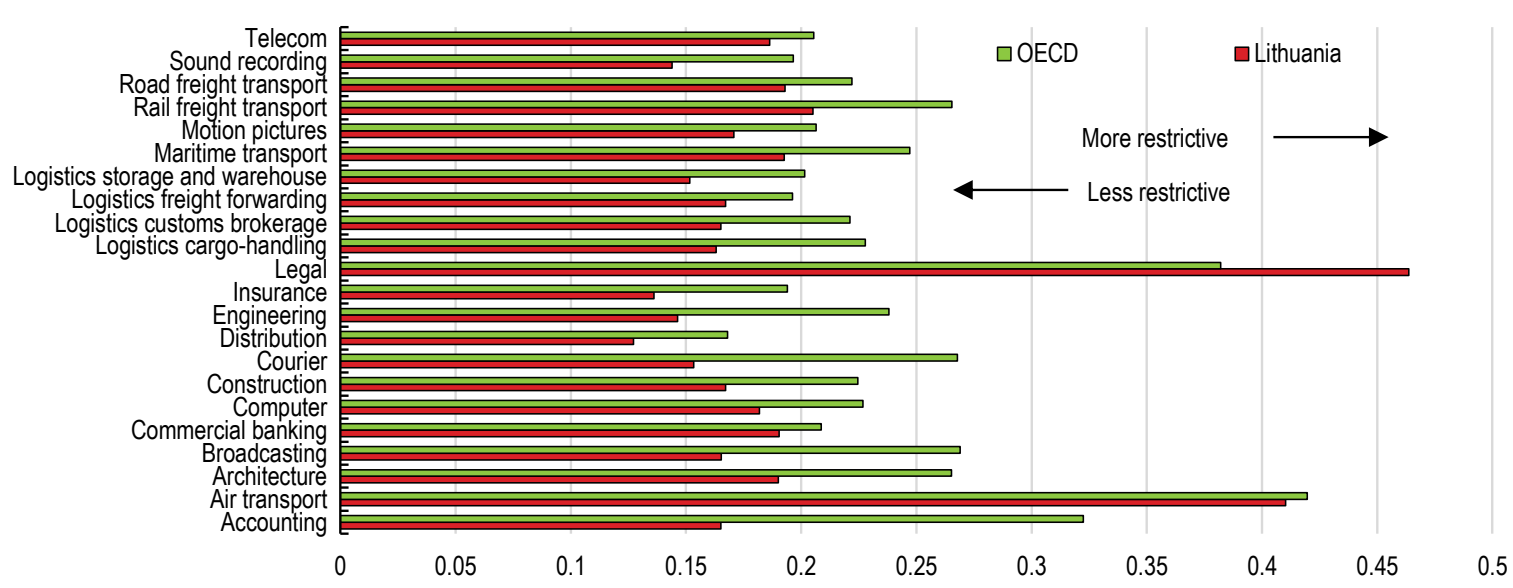

Source: OECD Product market regulation database.

StatLink 제에 http://dx.doi.org/10.1787/888933788548

More specifically, a law adopted in early 2017 eased restrictions, and the concomitant administrative burden, on the employment of workers from non-EU countries for selected professions. It exempts professions in approved shortage occupation lists from a work permit or the labour market test (Box 1). The law also improved the employment possibilities for non-EU students (part-time) and graduates in Lithuania, providing more flexibility for entrepreneurs, while introducing a simplified start-up visa scheme for nonEU entrepreneurs planning to establish a business in Lithuania in a number of hightechnology sectors. As an additional step, more simplified visa rules came into force in early 2018 for foreign semi-qualified workers through the establishment of the verified companies list. The new procedure is scheduled to be assessed in the course of 2018 .

Recent reforms also eased investment and services restrictions to non-residents including in the areas of legal services and land acquisition. Amendments at end-2017 provide for the possibility for non EU-nationals to exercise as practicing advocates in Lithuania when their country enters in bilateral mutual recognition agreements on professional qualifications. Moreover, foreigners will be allowed to register as patent agents from 2018. With regard to land acquisition, recent changes removed reciprocity requirements (stipulating equal treatment of Lithuanian investors in the counterpart country) and relaxed regulation on the acquisition of agricultural land by abolishing professional experience requirements.

These initiatives complement other recent reforms to boost Lithuania's attractiveness for foreign investors such as improvements in the regulation for free economic zones and the modernisation of labour relations (see below). The easing of employment restrictions for non-EU workers with qualifications in high demand can also help Lithuania to meet skill needs in growing sectors, for instance, information technology.

Barriers to investment could still be lowered further:

- The government plans to introduce further amendments with regards to the employment regulations of highly qualified non-EU workers, introducing the possibility for such employees to work on the basis of a national visa rather than a 
residence permit (Blue Card). Immigration procedures are expected to speed up further by the establishment in 2020 of the Electronic Migration Cases System (MIGRIS), enabling applications for residence permits or national visas in Lithuania, and their process, to be done electronically. Ensuring the timely implementation of the new system is important. A careful examination of the economic impact of remaining labour market tests for non-EU workers would be advisable.

- Some barriers for foreigners to do business in Lithuania also remain in some other areas. For instance, nationals from non-EU countries are now allowed to exercise as practicing advocates in Lithuania but only if their countries entered into bilateral mutual recognition agreements on professional qualifications (see above). In addition, there are limitations on the acquisition of real estate by foreigners, although nationals from European Economic Area and OECD are exempted (OECD, 2017b). Greater competition is also key to higher productivity. There is scope to increase competition in some key sectors, such as railways, where there is only one main undertaking providing freight transportation services. The government plans to reorganise the state-owned enterprise Lithuanian Railways ("Lietuvos geležinkeliai"), separating it into different companies for passengers, cargo and infrastructure management, which would be welcome. Devising packages of reforms can help reduce resistances to change from stakeholders.

- Investment conditions would also benefit from a further reduction in administrative burden for businesses. While starting a business has become significantly easier in recent years, firms operating in Lithuania still face administrative burdens arising, for instance, from complex licensing or administration procedures or lengthy insolvency procedures (see below). Current efforts to develop a methodology for the calculation of compliance costs, and evaluate such costs for certain sectors (chemicals and transportation sectors) are welcome. The new methodology should be progressively applied to all key sectors of the economy identifying the areas with scope for reducing these costs.

- A licencing reform is also underway, aiming to simplify the system, with most of the legislative changes approved by Parliament. The screening process that commenced in 2012 indicated large scope for improvement in this regard including, for instance, 9 activities which should no longer be licensed and 45 activities that should be started by simple submission of a declaration. Simplified procedures are expected to reduce administrative burden on businesses, stimulating investment. These efforts need to be supported by a coherent framework to monitor the implementation of regulatory reforms and evaluate their effectiveness (OECD, 2015a). 


\section{Box 1. Reforms in employment procedures for foreign workers: main provisions}

A new Law on the Legal Status of Aliens, which took effect on 1 January 2017, introduces a number of amendments that simplify employment procedures for workers from non-EU countries with skills in short supply in the Lithuanian labour market. In particular:

- The law provides for two lists of occupations in short supply: one for high-skilled ("High-Skilled Occupations in Short Supply"), covering 27 occupations; and another ("List of Occupations in Short Supply") for occupations requiring lower professional qualifications such as machine operators and international transport vehicle drivers. The latter list is approved semi-annually by the Lithuanian Labour Exchange.

- For the highly qualified professionals, the 2017 law eases travel and employment conditions. The issuance period of temporary residence permits is reduced for professionals from non-EU countries whose occupation is in the list of "HighSkilled Occupations in Short Supply". Moreover, a greater number of foreign workers qualify under the new arrangements for a temporary residence permit (Blue Card). The minimum salary level that an employer has to pay to such workers was reduced from twice the average gross monthly salary to 1.5 times. In addition, highly qualified professionals are exempt from the labour market tests (requiring that a work permit is issued to a non-EU worker if there is no specialist in Lithuania meeting the employer's qualification requirements); under the previous arrangements only the highest-paid workers were excluded. Moreover, the professional experience (at least five years) of a foreign worker is now recognised as an equivalent to higher education qualification.

- Administrative procedures for incoming workers were made simpler, including through a shortening of the period of the issuance of a temporary residence permit (Single Permit) for non-EU workers with occupations included in the List of "Occupations in Short Supply".

- The law eases access to employment for graduates in Lithuania who intend to work according to the qualification acquired by abolishing requirements for a work permit or labour market test for such workers. Also, a work permit is no longer required for foreign students in Lithuania who work-part time.

- A simplified start-up visa scheme for non-EU entrepreneurs with plans to operate in certain fields of high technology (e.g. information and technology, biotechnologies, electronics) was introduced. An evaluation committee assesses the application on the basis of the scale and innovation potential of the new business.

Source: Government of Lithuania.

\section{Enhancing the performance of state-owned enterprises}

State-owned enterprises (SOEs) account for 3.2\% of total employment, above the $2.4 \%$ OECD average (OECD, 2016d). As of end-2016, there were 118 SOEs in Lithuania, mainly in the energy, transportation and forestry sectors. Around two-thirds of SOEs engage in commercial activities, either exclusively or in combination with public policy objectives 
(Bank of Property, 2017). At the beginning of 2018 due mostly to the consolidation of 42 forestry and 11 road maintenance enterprises, 66 SOEs remained.

The average financial performance of SOEs has improved in recent years, but many still do not achieve the annual return on equity target set by the government, meaning that they absorb resources that could be reallocated to more productive firms. Only 16 out of 42 commercial SOEs (excluding the 42 forest enterprises that were subject to different requirements) achieved the 5\% average return-on-equity target over 2013-15 (Bank of Property, 2016), and this share hardly improved in 2016 (Figure 17) (Bank of Property, 2017).

Figure 17. SOEs performance varies across sectors

Returns on equity of state owned enterprises, 2013-15

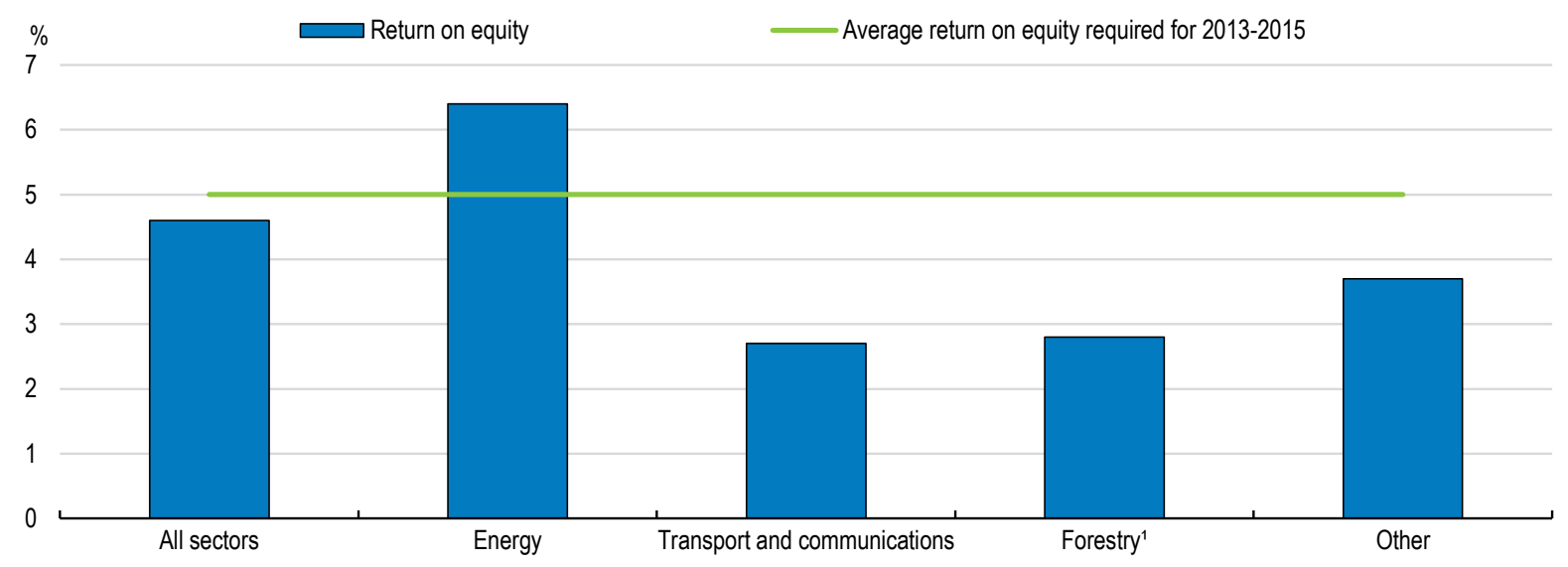

1. As forest enterprises were not subject to the return on equity requirement, their results were not included in the average 2013-2015 return.

Source: State-owned enterprises in Lithuania, Annual report 2015.

StatLink त्गा5 https://doi.org/10.1787/888933789232

The under-performance of state-owned enterprises is likely to reflect weaknesses in corporate governance. Lithuania has made considerable progress in recent years in aligning the governance framework for SOEs to the OECD SOE Guidelines. However, the 2015 OECD Review of the Corporate Governance of State-Owned Enterprises: Lithuania identified some crucial shortcomings in SOEs' ownership and corporate governance arrangements (OECD, 2015b). These include insufficient separation of the government's role as owner and regulator of SOEs, the absence of a centralised ownership entity to induce a greater separation of these functions, limited operational independence of SOE boards, weak corporatisation and concerns about the quality and credibility of SOEs' financial reports.

A number of recent reforms aim to address such shortcomings. These include, notably, the transfer of the ownership coordination function from the Bank of Property to an independent public institution to better separate operation and monitoring. Moreover, the budget of the Governance Coordination Centre (GCC) - established in 2012 to monitor and report on SOEs' compliance with the state's disclosure standards for such enterprises - was increased substantially to strengthen its monitoring capacity. Progress in this area is important. In addition, disclosure standards became mandatory for large SOEs. The compliance with the new provisions needs to be monitored closely, including through high 
quality auditing. The government has also adopted new rules which require a higher proportion of independent members on SOE boards from early 2018. Political appointees are barred from serving on boards. Moreover, a new nomination process for SOE board members was introduced which includes the use of personnel selection agencies, with the potential to make recruitment decisions more transparent.

These reforms, along with the restructuring underway in the state-owned forestry and road maintenance sectors, are proceeding as planned and should go hand-in-hand with increased accountability for boards of directors and managers for achieving results. Plans are also underway to fully corporatise a number of commercially-oriented SOEs that are currently subject to statutory legislation rather than company law. Only a small number of enterprises is to remain as statutory enterprises, with some undergoing mergers and others being liquidated or converted into public institutions or private/public limited liability companies. The government plans that by the end of 2020, entities with legal status of a state enterprise will cease to exist. This is in line with international practices (OECD, 2017c). Ensuring that SOEs are subject to the same laws and regulations as private companies is essential for safeguarding competition and productivity (OECD, 2015b).

\section{Boosting business dynamics through wider financing options}

New, dynamic firms spur productivity growth by increasing competitive pressures on incumbents and enabling knowledge diffusion. Innovative start-ups can also promote inclusive growth by reducing inter-firm wage dispersion (OECD, 2016c; OECD, 2017d). The share of "high-growth" enterprises in total is low in Lithuania compared to the OECD average, indicating scope for policies that promote firm turnover (Figure 18).

Figure 18. Firm dynamics can be improved

High-growth enterprises as a share of all enterprises ${ }^{1}, 2015$ or latest

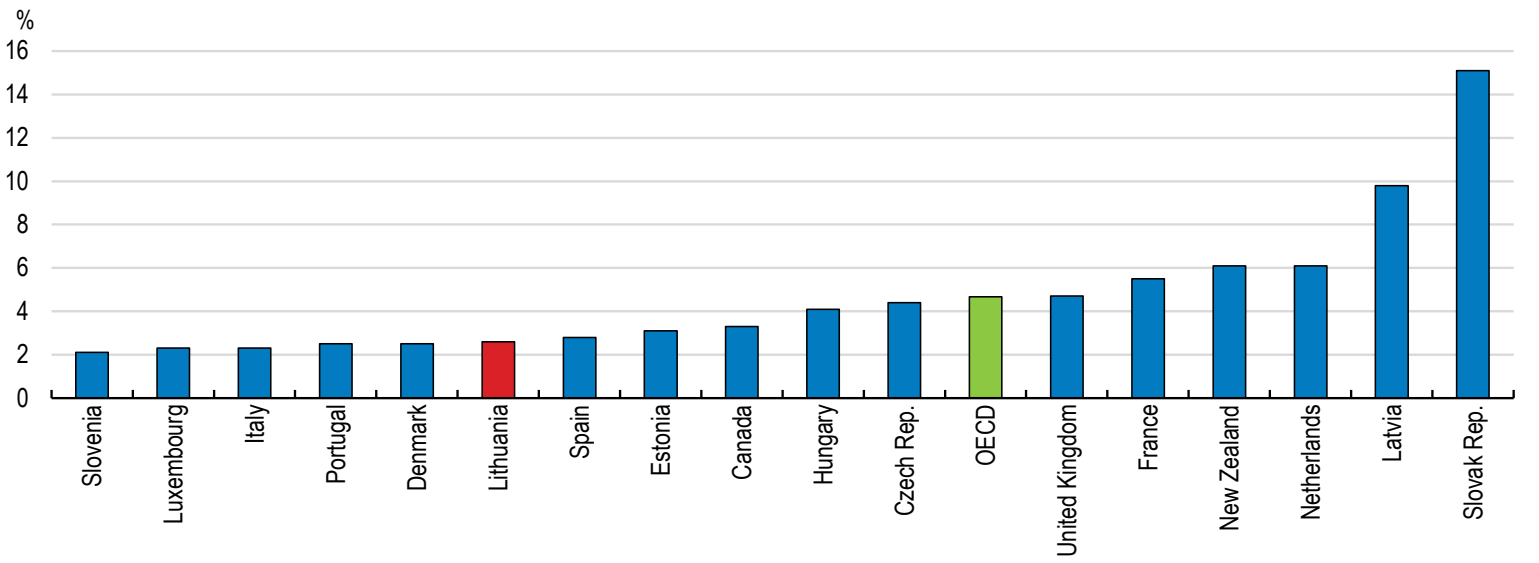

1. The rate of high growth enterprises is calculated as the percentage of high growth enterprises ( $20 \%$ or higher growth based on employment) on the population of active enterprises with at least 10 employees.

Source: OECD SDBS Business Demography Indicators database.

StatLink त्गाड़ https://doi.org/10.1787/888933789251

Reducing the financial constraints for high-potential firms is important (OECD, 2015c). Access to financing sources for business development has improved in recent years, but some Lithuanian firms still face constraints. Around 10\% of small and medium-sized enterprises (SMEs) in 2017 cited access to finance as the most important concern, above 
the EU average (Figure 19, Panel A). Firms facing financial constraints in Lithuania are often smaller and more productive with a key role in boosting innovation and creating jobs (OECD, 2016e). Equity financing - an important source in many countries to bridge the financing gap for young firms - was used by only 10\% of Lithuanian SMEs in 2017 (Figure 19, Panel B). Despite advances in the venture capital market in recent years, Lithuanian firms continue to rely highly on debt financing.

Figure 19. Access to finance for businesses

A. Evolution of access to finance as the main problem for SMEs

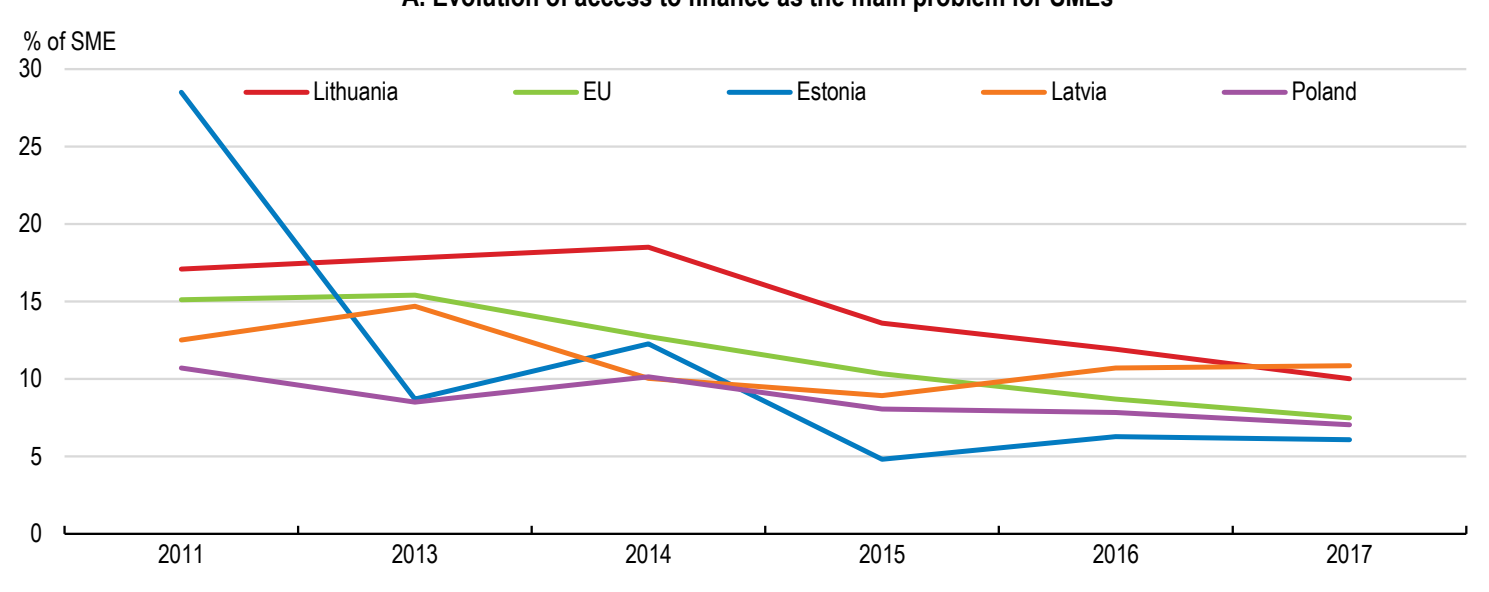

B. Relevant sources of financing for SMEs, 2017

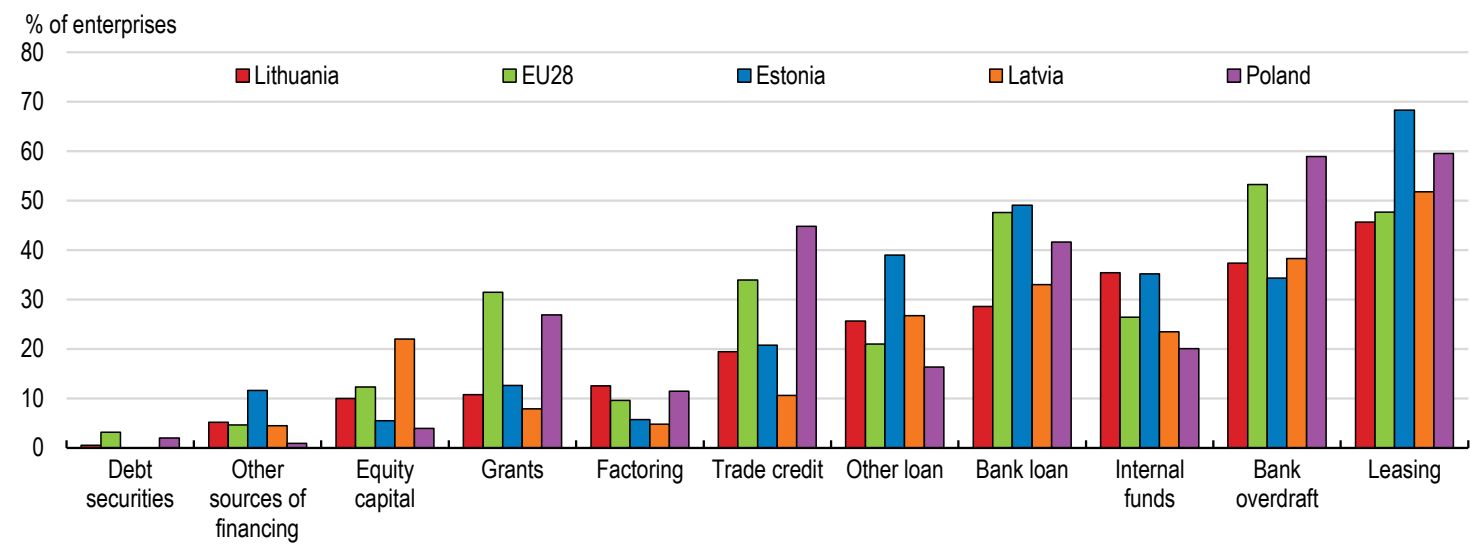

Source: European Commission, Survey on the Access to Finance of Enterprises.

StatLink तiाs

Several initiatives were recently introduced to help startups. A law in 2016 on crowdfunding is expected to promote alternative forms of business financing, comparable to new regulations in Austria and Germany to promote equity-based funding. Crowd-funding involves many investors making small investments for specific projects through an online platform (OECD, 2016a). The government in 2017 has also established three new venture capital funds, financed by EU structural funds and national resources, with six more funds to be established by 2019. These include, notably, a co-investment fund which enables business angels and capital venture teams to invest in young innovative start-ups together with the state. In addition to supply financing, business angels can provide business knowhow in a newly established company. 
As a further step forward, three new financial instruments for SMEs are to be launched. The first instrument, export credit guarantees, provides short-term export credit guarantees (up to two years) to SMEs exporting their goods (of Lithuanian origin) to non EU and non OECD countries. The second instrument, portfolio guarantees for factoring transactions, will provide short-term financing for SMEs with the aim to increase turnover and the development of SMEs' international activities. The government also plans to introduce crowd-funding loans, which allow financing SMEs through crowd-funding platforms. Such loans can be used to finance investments for new business, or to strengthen existing activities and promote development. The selection of financial intermediaries is underway.

The outcomes of the new initiatives in closing the financing gap for young innovative firms need to be monitored and assessed regularly, with changes in the design if required, given the importance of such firms in boosting productivity growth. More also can be done to increase awareness of funding opportunities among businesses. Measures that enhance the quality of projects and their presentation can also improve access to finance ("investment readiness") (OECD, 2016a).

\section{Streamlining insolvency procedures}

Lithuania's insolvency framework is weak, and the exit rate of firms is low (Figure 20). The survival of non-viable firms ("zombie" firms) drags down productivity and congests markets (Adalet McGowan et al., 2017). To facilitate the exit of less productive firms and to reallocate resources to more productive activities, the insolvency regime needs to be reformed. Effective insolvency regimes can also promote inclusiveness over the medium term by reducing across-firm differences in productivity and wages (OECD, 2017c).

Progress was made towards streamlining bankruptcy procedures in recent years, including through simplifying insolvency laws and reducing the period for decisions on appeals (World Bank, 2017). Moreover, since 2015, bankruptcy administrators in enterprise bankruptcy proceedings are appointed by courts on a computerised basis, increasing the transparency of the process. However, bankruptcy processes remain costly and timeconsuming in an international comparison (Figure 20, Panel C). Also, the recovery rate for investors is relatively low, which could discourage entrepreneurship (OECD, 2016e). An audit report highlights the need to introduce clearer and stricter rules regarding directors' liability of insolvent companies, so as to increase incentives for early filings for bankruptcy (NAO, 2014).

The government is currently drafting a comprehensive law on corporate insolvency, which changes the criteria for starting bankruptcy procedures and establishes clearer deadlines for filings. Amendments also aim to establish more favourable conditions for enterprise restructuring. It is envisaged, for example, that the petitions for initiation of bankruptcy and restructuring should be examined together, and that an enterprise in bankruptcy course should be provided with the possibility to terminate bankruptcy proceedings and convert them to restructuring proceedings. These reforms should go ahead. Recent OECD work highlights the need for insolvency regimes to offer the opportunity to debtors in financial difficulties to restructure early and, where necessary, facilitate exit predictably and expediently (Adalet McGowan and Andrews, 2016). Strengthening the use of expertise is key for raising efficiency, given that winding down or rehabilitating a company can be complex. Specialised judges and bankruptcy administrators are important in this regard. 
Figure 20. The insolvency framework can become more efficient

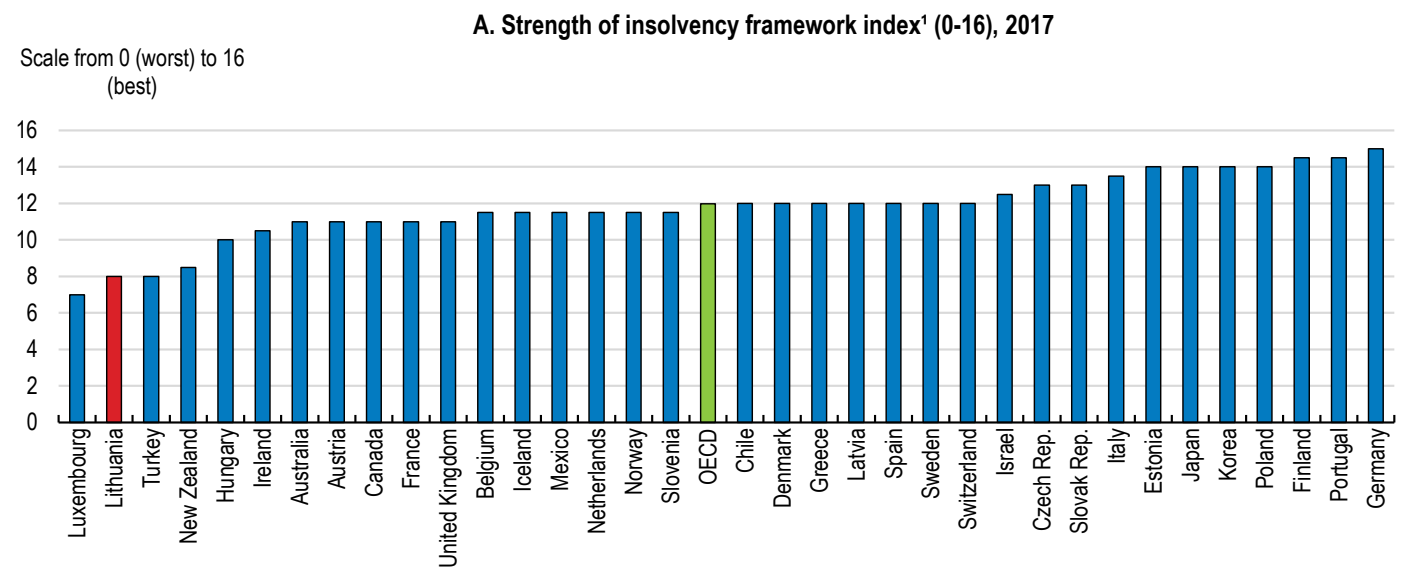

B. Business Demography Indicators - employer enterprise death rate ${ }^{2}$

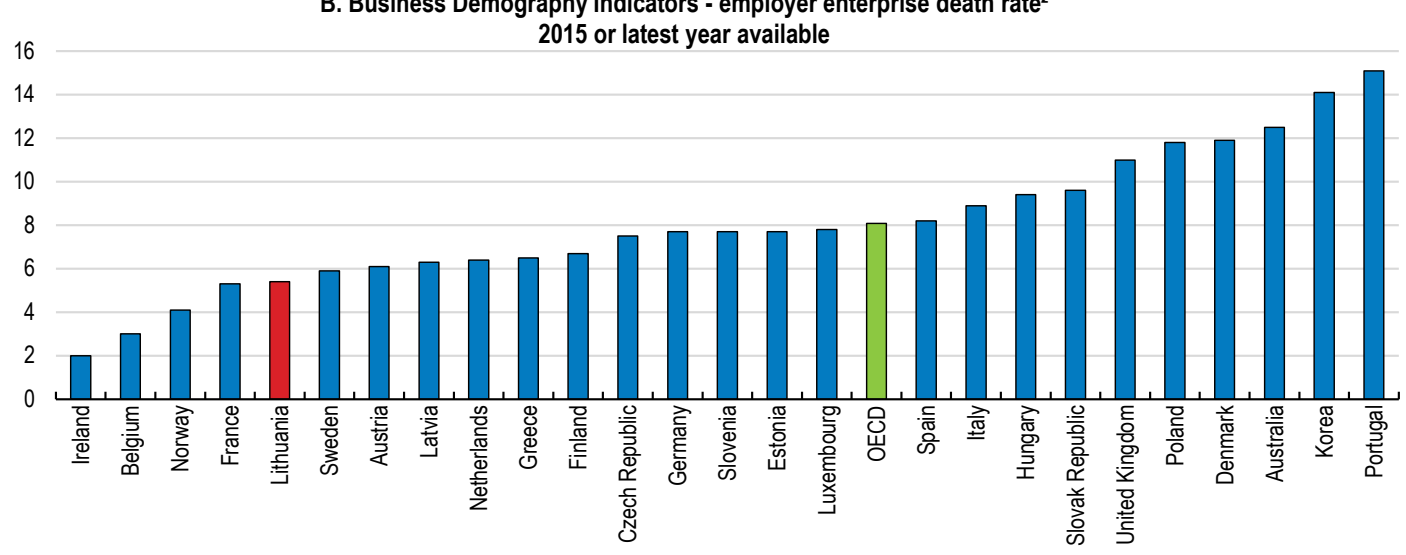

C. Resolving insolvency, $2017^{3}$

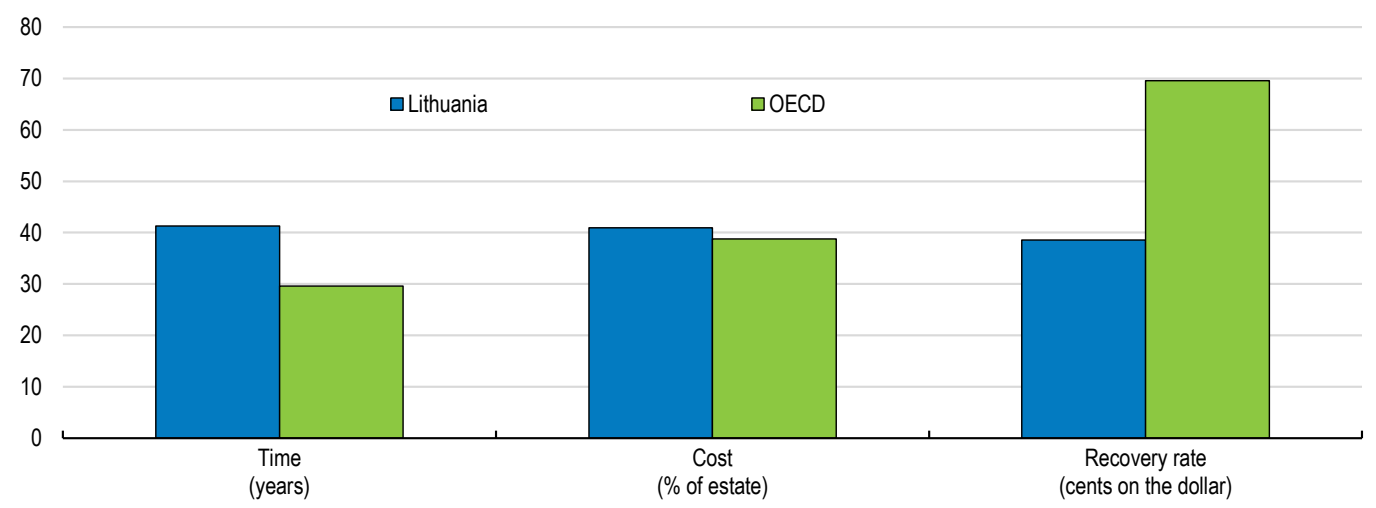

1. The strength of insolvency framework index is a composite indicator of the quality of the insolvency framework based on the time, cost and outcome of insolvency proceedings involving domestic legal entities. 2. Death rate: number of enterprise deaths in the reference period ( $\mathrm{t}$ ) divided by the number of enterprises active in the same period.

3. The indicators are normalised with respect to minimum and maximum values assumed among the OECD countries.

Source: World Bank Doing business 2018 database; and OECD SDBS Business Demography Indicators (ISIC Rev. 4) database. 


\section{Strengthening innovation capacity and diffusion of knowledge}

Securing faster income convergence will depend increasingly on strengthening innovation. Lithuania has improved its international innovation position, according to the 2017 European Innovation Scoreboard (EIS) (Figure 21, Panel A). It remains however a "moderate" innovator, on the basis of the summary index, with a performance of around $80 \%$ of the EU average (European Commission, 2017a). Despite progress, innovation inputs and outputs fall below the OECD median, with scope for greater efficiency (Figure 21, Panel B).

Figure 21. There is scope to catch up with more innovative countries

\section{A. EU Summary Innovation Index}

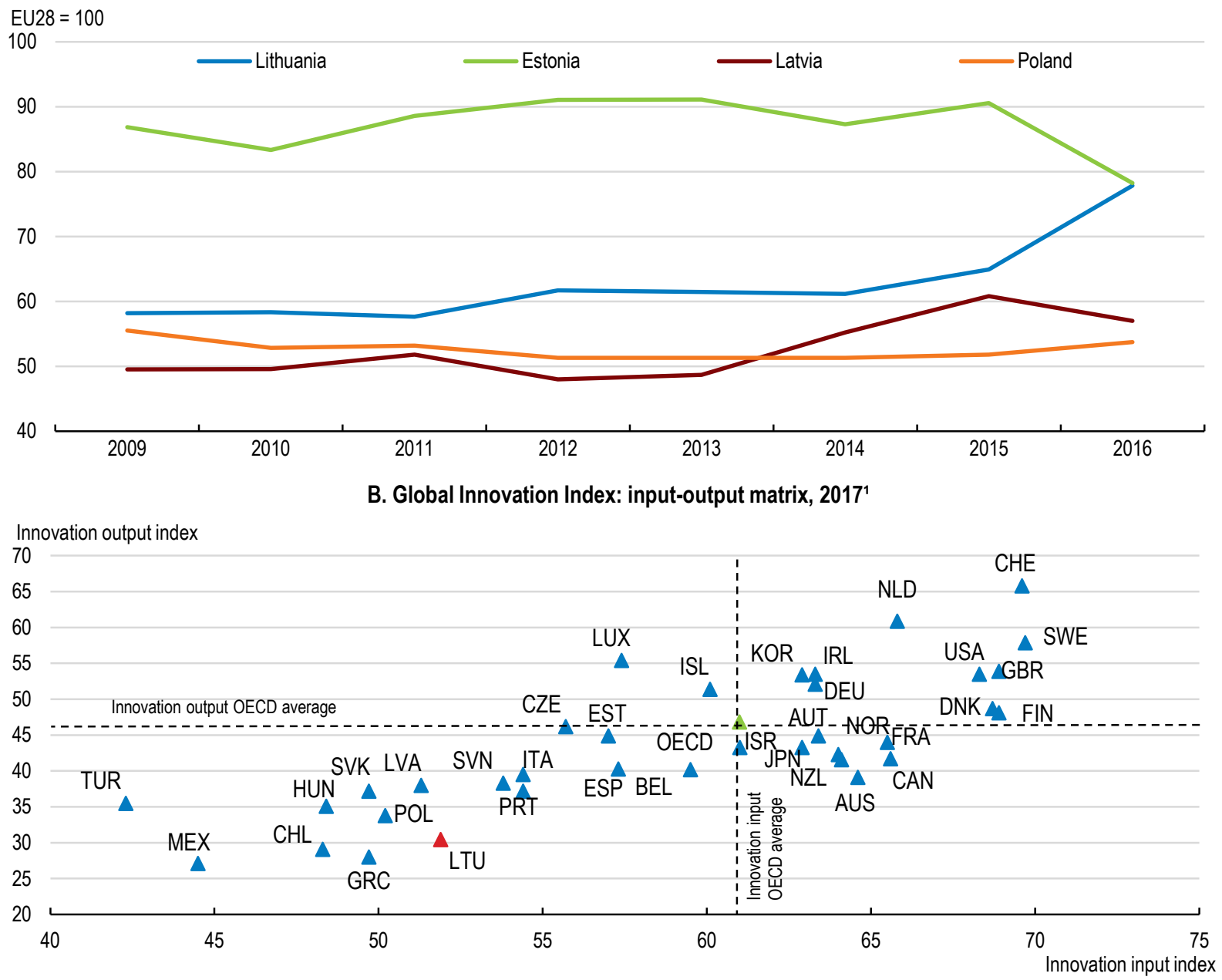

1. Innovation input measures include: institutions, human capital and research, infrastructure, market and business sophistication. Output measures include: knowledge and technology outputs and creative outputs. The indicators were normalised into the $[0,100]$ range, with higher scores representing better outcomes. Source: European Innovation Scoreboard 2017; and Cornell University, INSEAD, and WIPO (2016): The Global Innovation Index 2016: Winning with Global Innovation.

StatLink त्गा5 ht htps://doi.org/10.1787/888933789308

The proportion of innovative firms in Lithuania continues to lag behind the EU28 average, despite an increase in recent years (Figure 22, Panel A). Compared with the average EU 
business, Lithuanian firms reported a stronger process innovation activity over the period 2012-14 but the introduction of product and organisational or marketing innovations lagged behind. This may partly reflect the relatively poor capacity of businesses in Lithuania to absorb and adapt external knowledge and technologies (Figure 22, Panel B). This is of concern in view of the dependence of Lithuanian firms on external technology in catching up with the technological frontier and the need to participate more in global value chains (GVCs) (Figure 5). Increased investment in knowledge-based capital, including through improving digital skills, and greater collaboration between industry and research sectors that increases exposure to knowledge (discussed below) could boost firms' absorptive capacity (Vie et al., 2014; Maggs and Hathway, 2016). MOSTA (2017) further recommends a greater focus of research and innovation policy on firms that have potential to innovate or grow. Adjusting the research institutions' services towards business needs is important.

Figure 22. Firm level innovation and absorptive capacity are low

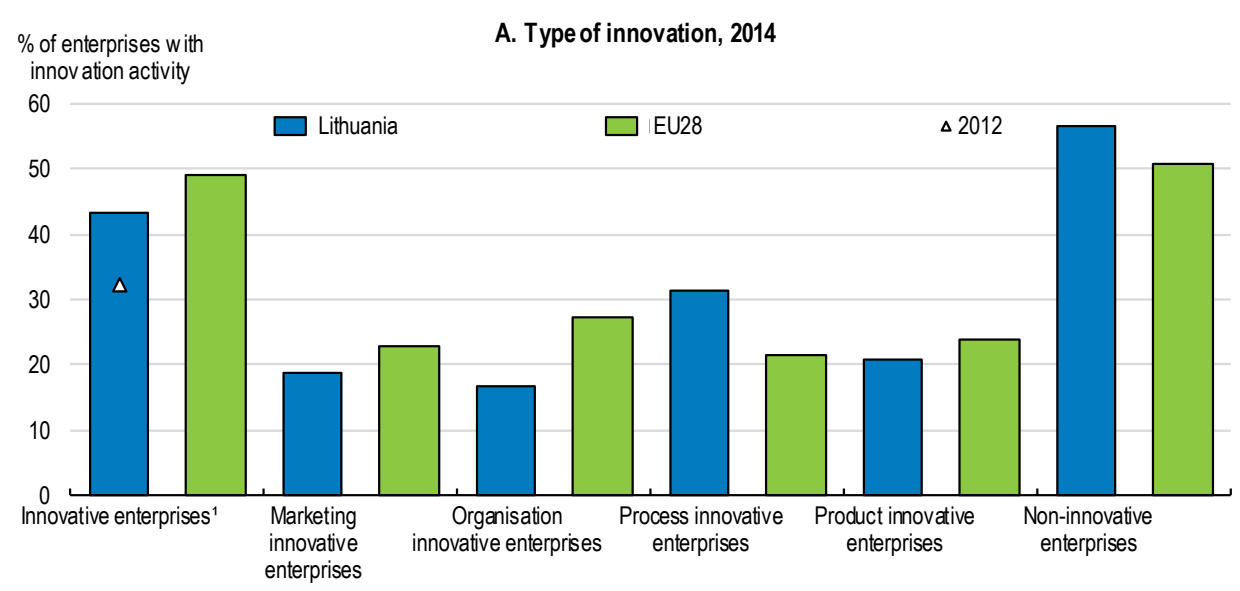

B. Global Innovation Index, 2017 - Knowledge absorption ${ }^{2}$

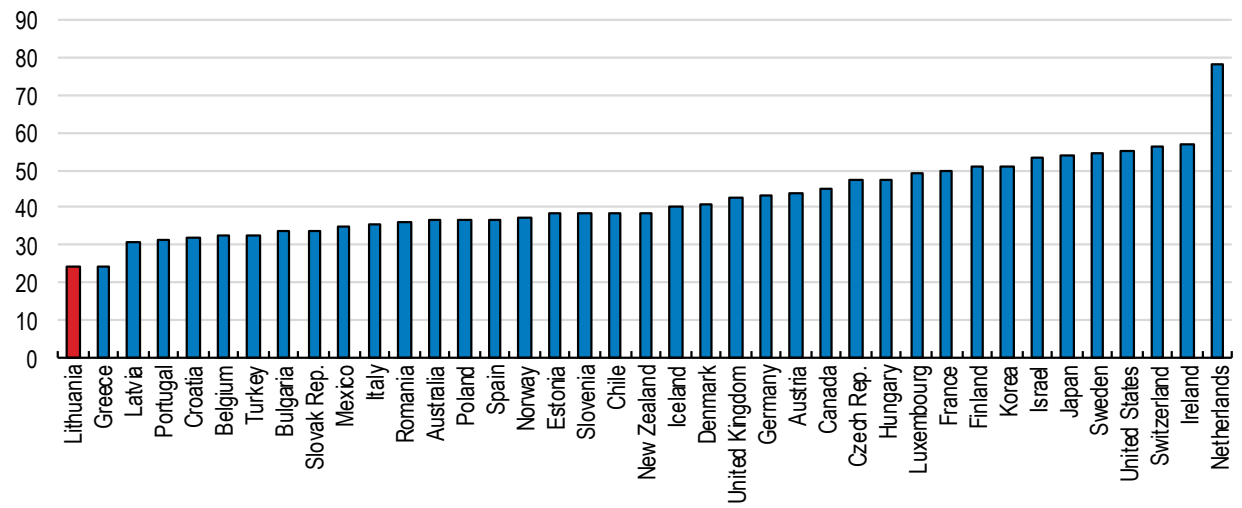

1. Including enterprises with abandoned/suspended or on-going innovation activities.

2. The knowledge absorption index is a composite indicator that measures how good economies are at absorbing and diffusing knowledge. It is based on the following indicators: intellectual property payments as a percentage of total trade; high-tech net imports as a percentage of total imports; imports of communication, computer and information services as a percentage of total trade; net inflows of foreign direct investment as a percentage of GDP and the percentage of research talent in business.

StatLink : הils https://doi.org/10.1787/888933789327. 
Business R\&D intensity remains low, despite generous company-level support schemes, even taking into account that the high tech sector is relatively small (European Commision, 2016a) (Figure 23). The generous R\&D tax incentives are hardly taken up. Along with an accelerated depreciation allowance for some $R \& D$ capital, the current scheme allows companies to deduct $300 \%$ of eligible R\&D expenditures. Furthermore, the tax incentive for companies investing into technological modernisation has been extended allowing from 2018 to reduce the taxable profits from the respective investment expenses up to $100 \%$, instead of $50 \%$ under the previous arrangements. Yet, in 2015, only 149 firms out of 79 840 operating in Lithuania were enrolled to receive tax incentives for $R \& D$, according to the official data. This is due in part to uncertainty regarding the definition of eligible R\&D and complex and lengthy application procedures, indicating scope for revisions (European Commission, 2016a). The fact that young innovative firms often do not make profits and limited awareness of the scheme may be other possible reasons for the low take up (OECD, 2016e; IMF, 2017a). Recent measures to better communicate the R\&D tax incentives to firms, through expert consultations and electronic information about the application procedure, are therefore welcome.

Figure 23. Business innovation is low despite generous tax incentives

A: Trends in business expenditure in research and development

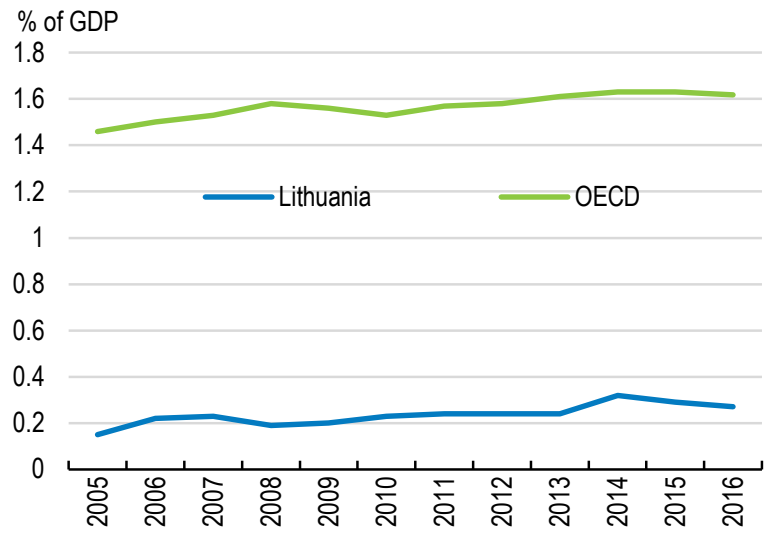

\section{B. R\&D tax subsidy rate, 2015}

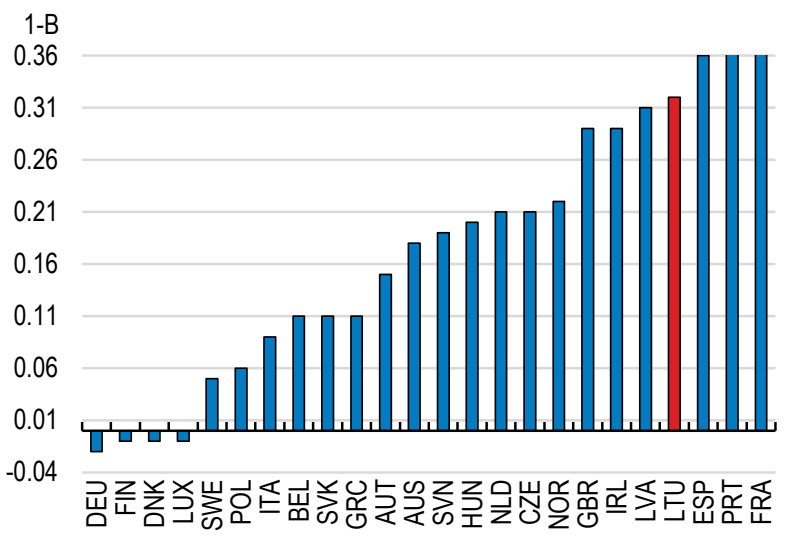

Note: The index is for small and medium profitable enterprises. The tax subsidy rate is calculated as ( $1-\mathrm{B}-$ index), where the B-index is a measure of the before-tax income needed to break even on 1 dollar of R\&D outlays (Warda, 2001). A decline in the B-index reflects an increase in R\&D tax generosity.

Source: Eurostat; and OECD, R\&D Tax Incentive Indicators, http://oe.cd/rdtax, March 2017.

\section{StatLink त्गा5 https://doi.org/10.1787/888933789346}

A further corporate income tax incentive supporting commercialisation of patented assets and copyrighted software created from R\&D activities performed in Lithuania was recently approved by Parliament. The new arrangement provides for a reduced corporate income tax rate of 5\% (instead of 15\%) to the taxable profits earned from use, sale or other transactions related to these assets. A number of countries have complemented their R\&D tax incentives with tax incentives on Intellectual Property ("patent boxes"). However, based on international experience, patent boxes favour holders of existing patents rather than entrepreneurs who do risky experimentation, which is an important driver to innovation (OECD, 2015d). The effectiveness of the new measure needs to be monitored. 
Fostering digitalisation is a key challenge going forward. New technologies can boost innovation and productivity and improve wellbeing, as information and knowledge become more widely available (OECD, 2017e). Lithuania ranks well in international comparison in terms of broadband coverage (fixed and mobile) (Figure 24, Panels A and B). However, the take up rate remains low. For instance, only $63 \%$ of the households had subscribed to a broadband connection in 2016, around 10 percentage points below the EU28 average (Figure 24, Panel C). The use of ICT by firms also remains limited (Figure 24, Panel D). Ensuring the right skills is key for adapting to technological changes and for safeguarding inclusion. Lithuania lags behind in the "human capital" component of the EU Digital Economy and Society Index, reflecting a relative low share of internet users in population and of ICT specialists in total employment (Figure 24, Panel E). Addressing skills mismatch and ensuring solid basic skills (discussed below) are important for strengthening the digital skill base (OECD, 2017e). Greater investment in knowledge-based capita (Figure 24, Panel F) and measures that improve firm dynamism are also important for the digital transformation.

Enhancing research-business collaboration on innovation is an additional key challenge. This is an increasingly recognised channel of knowledge transfer (OECD, 2015d). The collaborative activity by SMEs has picked up significantly in recent years, surpassing the EU average (Figure 25, Panel A). However, collaboration of firms with universities and research institutions remains limited compared with other OECD countries, especially in the case of larger firms (Figure 25, Panel B). Lithuania also has a low incidence of coauthored publications between industry and the research sector and a comparatively low concentration of researchers in the business sector, suggesting low mobility between the two sectors (Figure 25, Panels C and D). The share of researchers working in the business sector in Lithuania stands at around $16 \%$, well below the EU28 average close to $40 \%$.

Collaborative research can be improved by encouraging universities and business to engage more with each other. Policy measures, such as the innovation vouchers for SMEs to buy industrial or applied R\&D from selected public research institutions, and technology scouting, aiming to foster technology transfer from science to business (and vice versa) by searching and identifying new technological solutions, are welcome. Moreover, the Intellect programme, which provides grants to businesses, finances only projects jointly carried out by businesses and research institutions (IMF, 2017a). A regular assessment of the impact of these measures is advisable.

Increasing the government contribution for collaborative research conducted by public research institutions could be another policy option on the basis of international experience (OECD, 2017f). As a step in this direction, a new scheme for basic funding of universities and research institutes encompasses a number of criteria related to collaboration with business, such as the number of patents and joint academia-business publications. This reform is expected to increase incentives for researchers to acquire industrial experience. New measures aiming at improving the absorption capacity of private companies, including industrial doctorates and support for mobility of researchers between public and private sectors, are also in the right direction towards improving collaborative research. 
Figure 24. Indicators of digitalisation
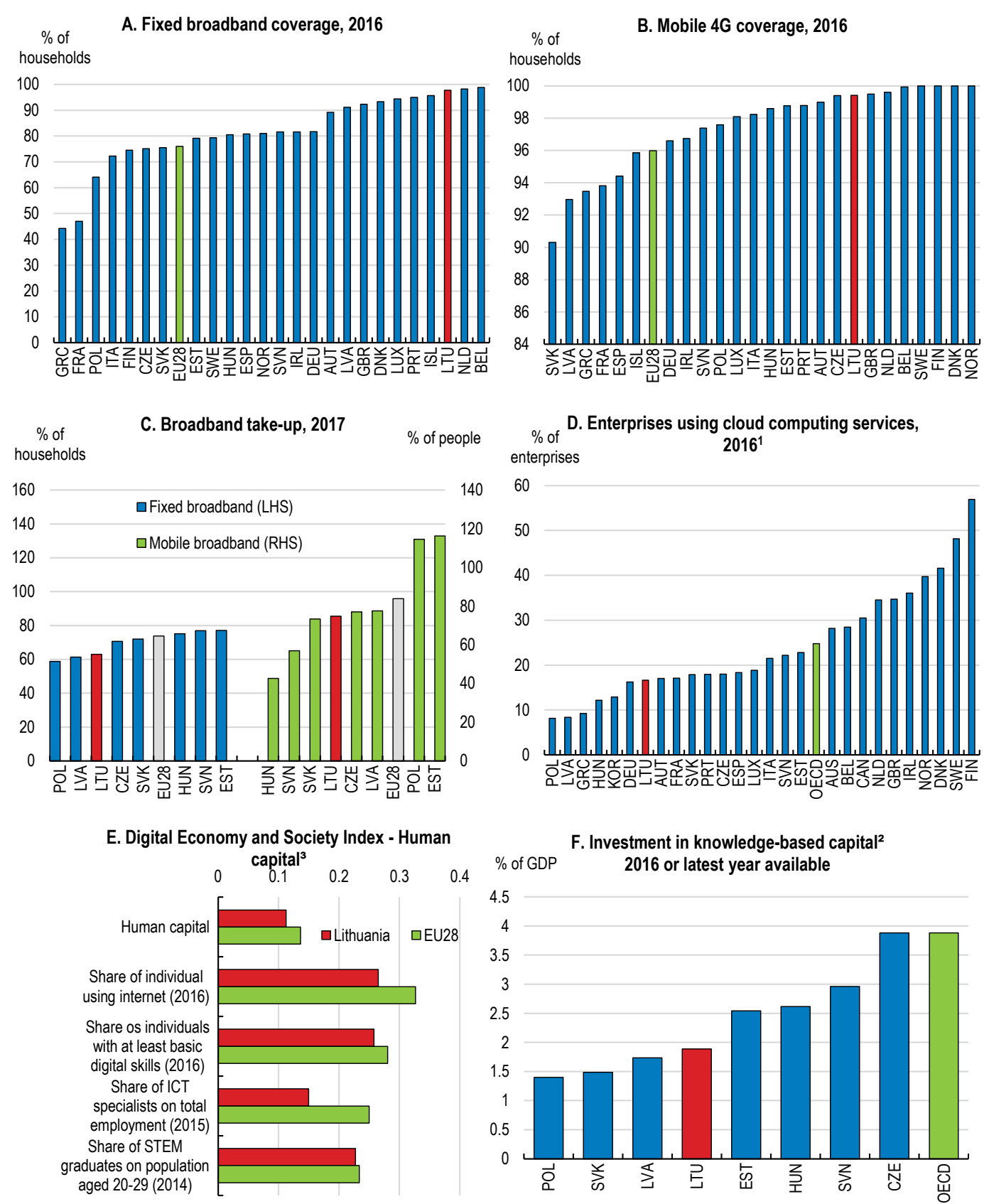

1. Cloud computing refers to ICT services used over the Internet as a set of computing resources to access software, computing power, storage capacity and so on. Data refer to manufacturing and non-financial market services enterprises with ten or more persons employed, unless otherwise stated. Size classes are defined as: small (10-49 persons employed), medium (50-249) and large (250 and more). OECD data are based on a simple average of the available countries.

2. Includes R\&D, mineral exploration and evaluation, computer software and databases, entertainment, literary and artistic originals, and other IPPs.

3. The indicators are standardised using a fixed min-max methodology (see http://ec.europa.eu/newsroom/document.cfm?doc_id=43048).

Source: European Commission, Digital Scoreboard; and OECD Digital Economy Outlook 2017.

StatLink הताsम https://doi.org/10.1787/888933789365 
Figure 25. There is scope to increase collaborative research

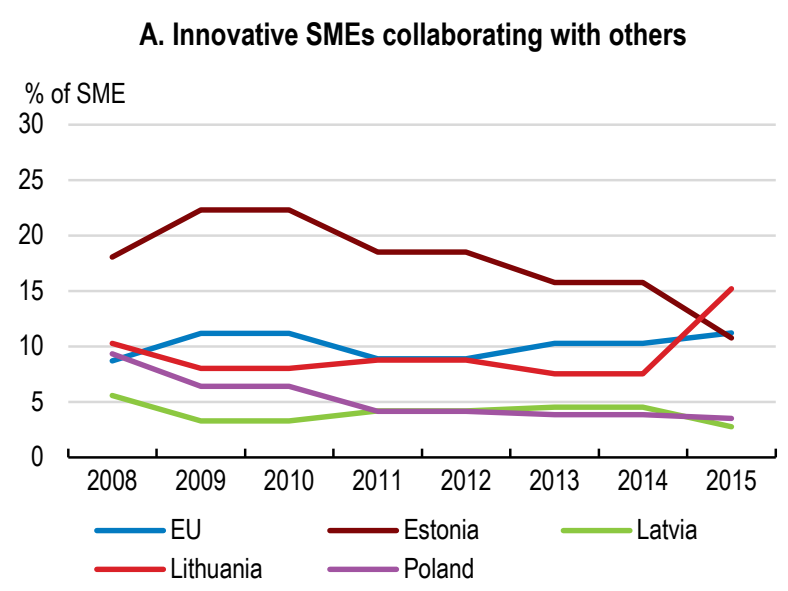

C. Public-private co-publications per million population, 2015

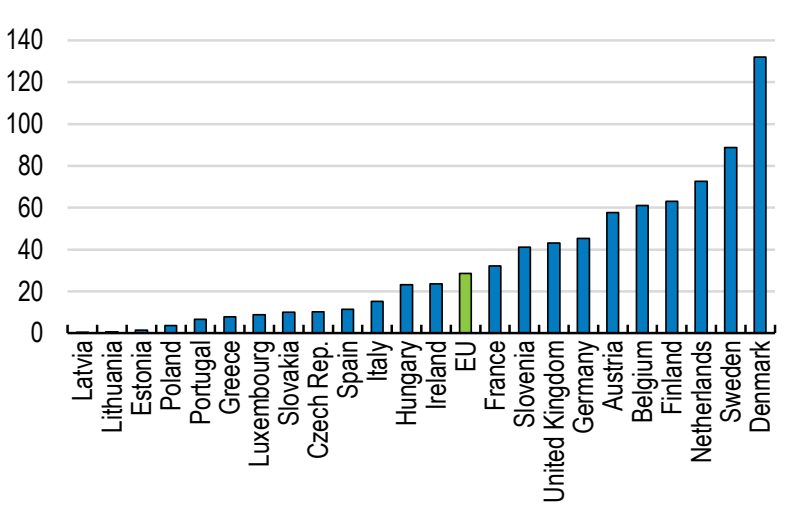

B. Firms collaborating on innovation with higher education or research institutions, 2014

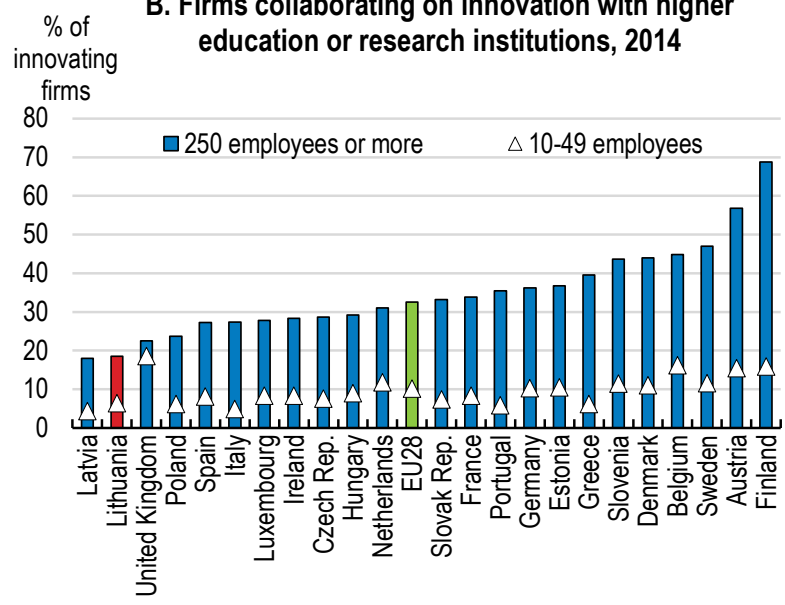

D. Share of researchers by performing sector 2015 or latest year available

$\square$ Higher education, government and private non-profit 口Business enterprises

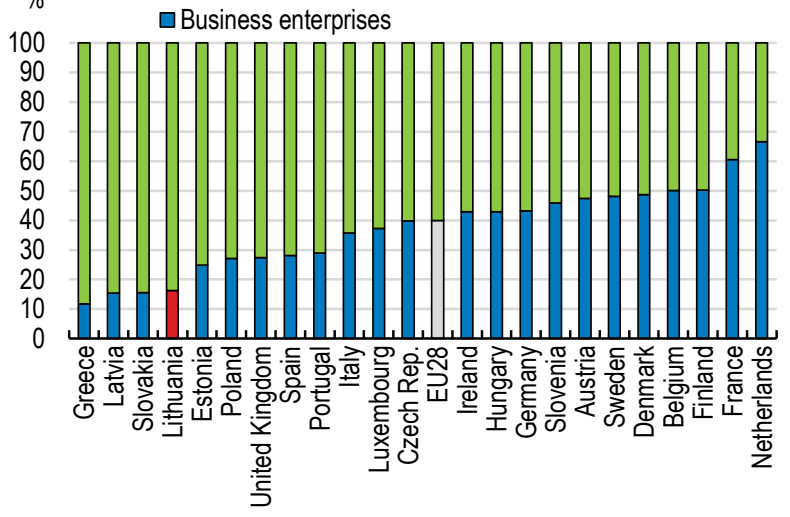

Source: European Innovation Scoreboard; and Eurostat.

StatLink त्ञाज https://doi.org/10.1787/888933789384

Finally, intellectual Property (IP) policies that favour collaboration are important. Knowledge and technology transfer activities are quite new in Lithuanian universities. Some successful examples of IP management models, however, provide indications that changes are underway. The management of IP created by the universities could be improved by providing financial incentives for the commercialisation of innovation outputs and knowledge transfer. For instance, following recent reforms, funding arrangements for competitive grants in Australia require universities to list their patents generated by publicly funded research (Australian Government, 2016; OECD, 2017f). It is essential that IP owners have the skills for negotiating with businesses.

Strengthening collaboration does not imply a need for reduced attention to basic research. The OECD Innovation Imperative (OECD, 2015d) stresses the significantly larger knowledge spillovers generated by basic research compared to applied research, while also making applied research more productive. Moreover, basic research facilitates access to international knowledge (OECD, 2015d). 
Greater coordination is needed to strengthen the innovation system. There are many institutions with advisory and implementation functions under the various ministries with weak coordination among them, which leads to fragmentation of policies and their delivery and functional overlap (OECD, 2016a; IMF, 2017a). Moreover, a plethora of support programmes and instruments increases institutional complexity and administrative costs and makes it difficult for firms to achieve the most of available support. The low take up rates of the R\&D tax incentives scheme can be an indication of such complexity. The establishment of the Strategic Council for Research Development and Innovation is a step toward a greater horizontal coordination. The council's role currently includes reviewing institutions involved in research development and innovation. Its functions could be strengthened, including reviewing the science, technology and innovation (STI) policy mix (OECD, 2016a). The government should continue the implementation of the institutional reform of innovation policy by improving coordination and consolidate agencies and support programmes where overlaps exist, based on a careful and well-evidenced assessment, as recommended by the OECD Innovation Policy Review for Lithuania (OECD, 2016a).

\section{Improving infrastructure}

Good infrastructure supports private investment and innovation and facilitates trade and knowledge diffusion. It could also make growth more inclusive, through enhanced labour mobility (OECD, 2017d). The perceived quality of overall infrastructure in Lithuania has edged up in recent years, but remains below the OECD average (Figure 26). Transport infrastructure, in particular, could be improved. There is a need to develop safer road infrastructure - the number of road fatalities remains among the highest in the EU - and upgrade port and air transport infrastructures. In the rail sector, there is a shortage of lines with double tracks, which causes bottlenecks, and a low degree of electrification; only $7 \%$ of rail tracks in Lithuania are electrified (European Commission, 2017b). Moreover, Lithuania's transport and energy (electricity, gas) networks need be integrated further with the rest of Europe.

Figure 26. Infrastructure quality in international comparison

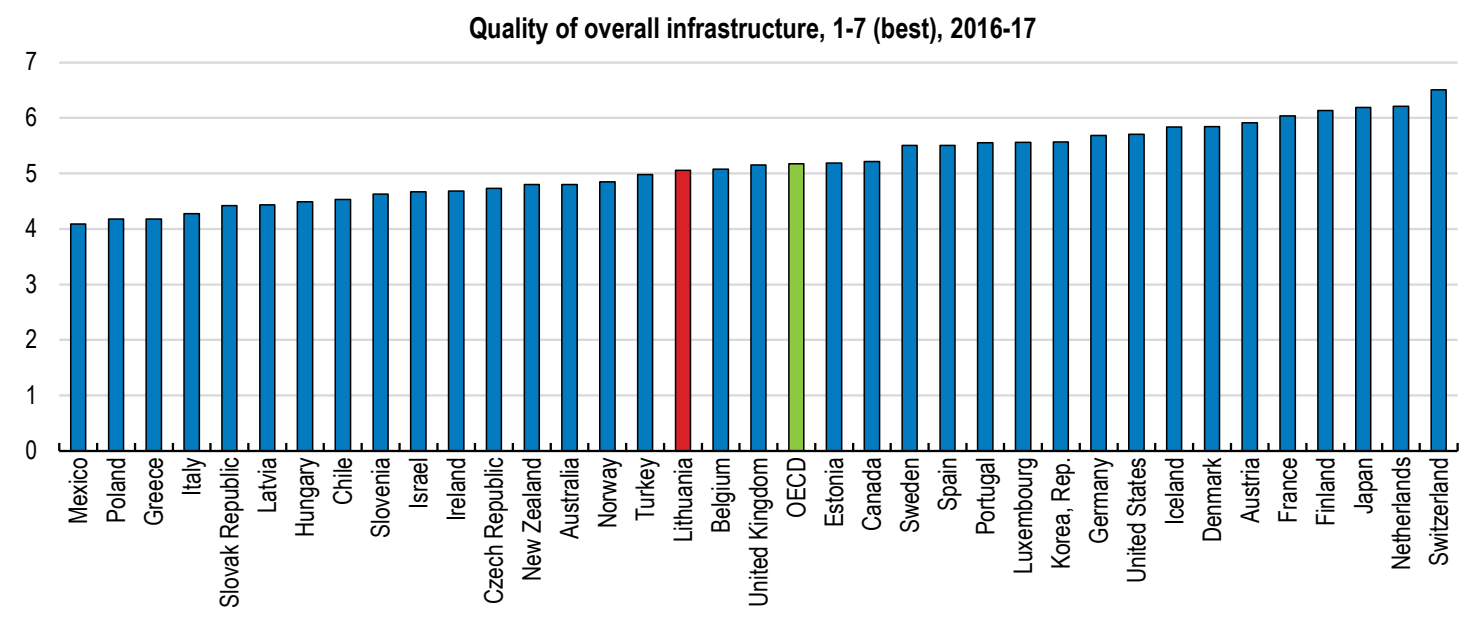

Note: The score is based on the assessment of business leaders operating in the country to the question: how would you assess general infrastructure (e.g. transport, telephony and energy) in your country? [ 1 = extremely underdeveloped - among the worst in the world; 7 = extensive and efficient - among the best in the world]. Source: World Economic Forum Global Competitiveness Index dataset.

StatLink तilst https://doi.org/10.1787/888933789403 
A number of noteworthy projects, co-financed by the EU, are underway. The Rail Baltica project will connect the Baltic states to the standard-gauge European network. Other projects attempt to modernise water and air transport infrastructure. In addition to economic gains, reforms in the transport sector would have environmental benefits by reducing bottlenecks. Moreover, energy supply has been diversified by connecting the electricity grid with that of Sweden (NordBalt) and Poland (Litpol); this allows Lithuania to import significantly more electricity from Europe improving supply certainty. In the gas sector, the construction of a new gas interconnector linking Lithuania with Poland (GIPL) is scheduled to be completed by the end of the decade. GIPL is of key importance as upon completion it will connect the gas networks of all the Baltic countries with that of continental Europe (European Commission, 2017b).

These initiatives go in the right direction as better infrastructure can increase competition and reduce cost for Lithuanian firms. However, enhancing efficiency of public infrastructure spending is crucial to achieve the highest possible benefits from public investments. A report by the National Audit Office of Lithuania, assessing the management of the state investment programme in 2015, highlighted that the programme planning suffered from a poor coordination and that project selection procedures were often lacking rigorous analysis, with limited requirements for performance reporting (NAO, 2016). As a positive step, from 2018, a cost-benefit analysis will be required for all investment projects financed by the Lithuanian budget. This could increase the efficiency, as well as transparency, of the selection process.

\section{Helping individuals to meet their productive potential}

\section{Ensuring relevant skills}

The economy is booming and wages are growing fast. However, Lithuania still faces important long-term labour market challenges having an impact on productivity and inclusiveness over time. The high structural unemployment rate reflects inefficiencies in the allocation of labour resources. Moreover, skill shortages contribute to supply constraints putting pressure, along with the shrinking workforce, on inflation and labour costs. ICT professionals and engineers, with a key role for the digital economy, are among the occupations that are in short supply of workers, as are health professionals (European Commission, 2016b).

The share of workers with skills mismatch in Lithuania is above the OECD average (Figure 27, Panel A). Over-skilling is generally more common than under-skilling. Recent OECD research concludes that, lowering skills mismatch in Lithuania to best practice is associated with productivity gains of around $10 \%$ compared to the OECD average of $6 \%$ (Adalet McGowan and Andrews, 2017).

The field-of-study mismatch (when workers are employed in a different field from what they have specialised in) is also high in international comparison (Figure 27, Panel B). Despite a highly educated workforce, finding workers with the right skills appears to be a significant constraint for over $40 \%$ of firms on the basis of recent survey data (Figure 28). High emigration and certain restrictions on non-EU workers, as well as limited participation in lifelong learning, partly explain the lack of suitable labour. This is exacerbated by the insufficient quality of the domestic education system. 
Figure 27. Labour resources could be allocated more efficiently
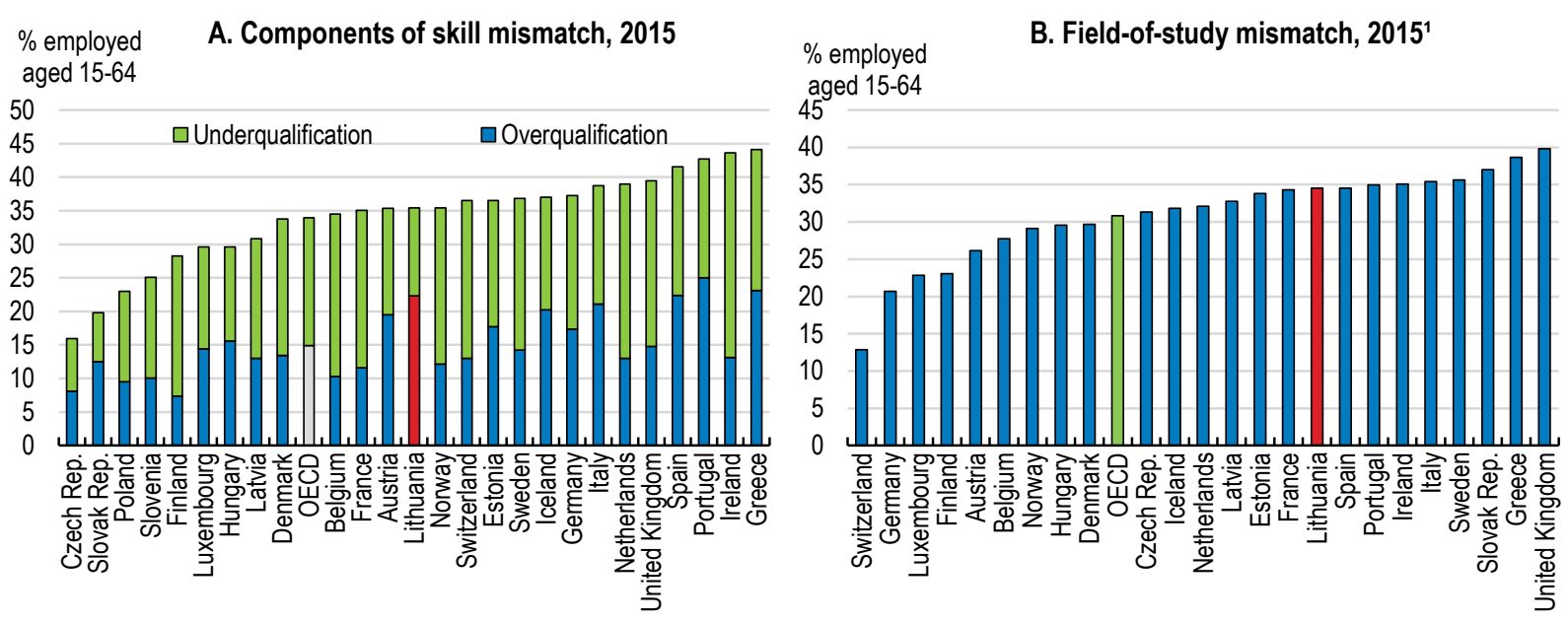

Note: The OECD average is calculated on the 25 available countries only.

1. Field-of-study mismatch arises when workers are employed in a different field from what they have specialised in.

Source: Adalet and Andrews, 2017; and OECD Skills for Jobs Database.

StatLink הत्गा5 https://doi.org/10.1787/888933789422

Addressing skill mismatches requires a tertiary education system that is more responsive to changing labour market needs. It is not uncommon for university graduates to subsequently enrol in vocational training (IMF, 2017b). Recent initiatives towards improving the labour market relevance of tertiary education are welcome. These include a new law in 2016 that provides for increased cooperation between higher education institutions and social partners on curriculum development and the expansion of workbased learning opportunities in tertiary education (European Commission, 2016a). In addition, the 2016 law opens pathways from professionally-oriented courses to traditional master's programmes. In response to reported shortages, the government has also recently increased the number of vouchers (public funds to cover the full cost of studies) for tertiary studies in areas such as ICT, mathematics and engineers. Moreover, the mandate of sectoral professional committees (advisory bodies coordinating qualification-related issues in a specific sector of the economy) was enhanced to include higher education qualifications, and the system of professional standards now applies to all levels of qualification. However, explicit incentives under the current tertiary funding system to align the provision of tertiary education to labour market needs are generally missing (Gruzevskis and Blaziene, 2015).

Plans for a more direct link between tertiary education funding mechanisms and labour market demands, including through differentiated awards to institutions for courses that provide skills closely linked to labour market needs, are welcome. In particular, a new funding model for tertiary education is underway which will relate part of the public funding (up to $20 \%$ ) to the achievement of the performance outcomes agreed with the tertiary institutions. This will be complemented by the development of a more rigorous methodology for assessing labour market needs and keeping track of graduates' employability. These reforms should go ahead. Incorporating graduate labour market outcomes to providers' funding formulae could be considered. It is further important to assess carefully whether the current funding arrangements have any unintended effects in 
terms of skill mismatches in view of differences in course fees and the alleged shortages in high-skilled occupations, such as ICT specialists and engineers. Better information to students about the labour market outcomes of graduates by field of study is important in this regard. The new human resources monitoring system, linking administrative data from education, training, employment, and tax systems, should improve such information but this needs to be made readily available to students (OECD, 2018a).

Figure 28. Lithuania has a highly educated workforce but the skill mix needs to improve

\section{A. Share of population aged 25-64 with tertiary education, 2016 or latest year available}

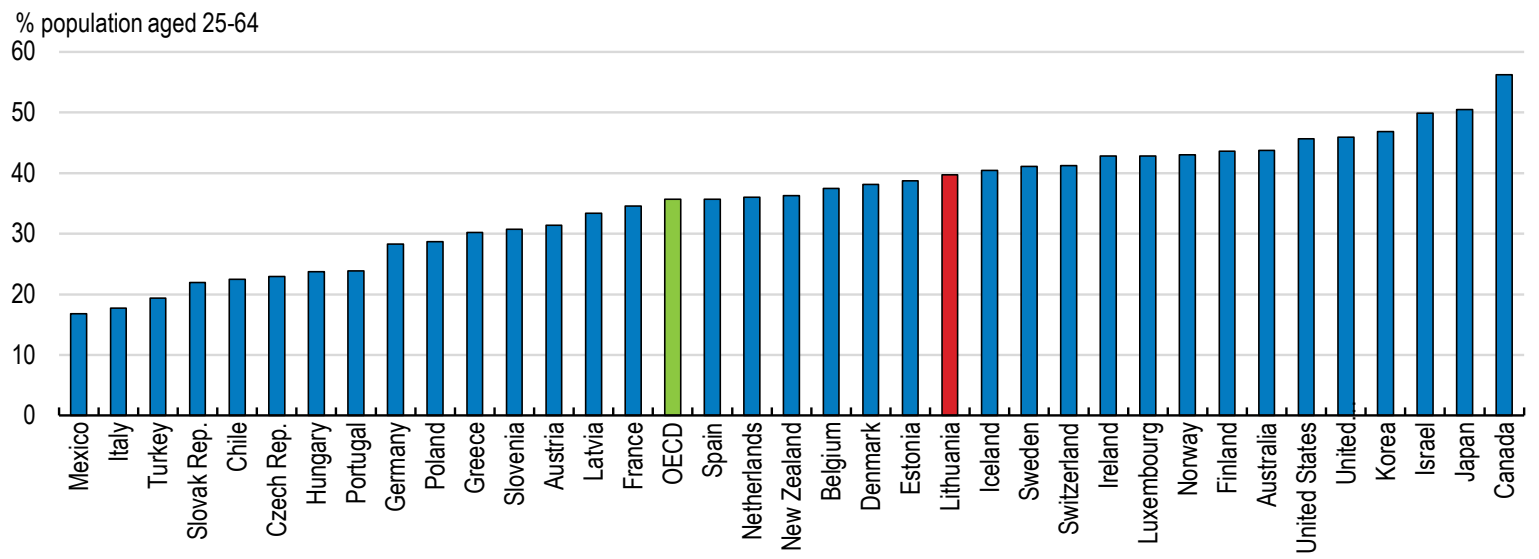

B. Major obstacles to investment $\%$ of all firms citing a major obstacle ${ }^{1}, 2015$

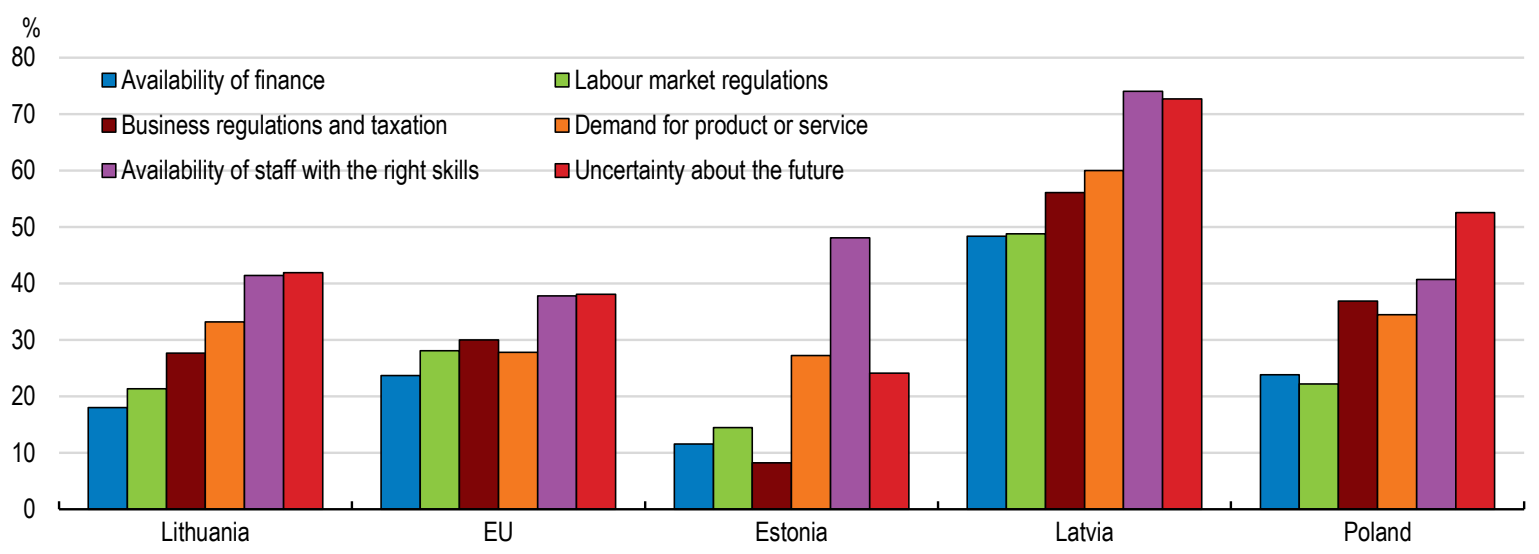

1. Firm responses to the question: "Thinking about your investment activities in your country, to what extent is each of the following an obstacle? Is it a major obstacle, a minor obstacle or not an obstacle at all?"'

Source: OECD Education at a glance 2017; and European Investment Bank - EIBIS, EIB Investment Survey.

StatLink त्ञाज https://doi.org/10.1787/888933789441

More work-based training is also necessary to meet the skills needs. Vocational education and training (VET) has relatively low enrolment rates and is largely school-based (Figure 29). Comprehensive efforts are underway to improve the attractiveness of VET and increase its labour market relevance. These include changes in the governance of VET that strengthen business involvement in the development and implementation of programmes and improvements in the technical competencies of VET teachers through training 
programmes in business enterprises (OECD, 2017g). Moreover, the VET curricula are being reformed, in close collaboration with the social partners, and transformed to the modular structure (European Commission, 2017c). In addition, 42 sectoral practical centres provide modern training facilities for VET students.

These are positive initiatives, but efforts need to continue if the national policy target for increased enrolment in upper-secondary VET from almost $27 \%$ in 2016 to $35 \%$ by 2022 is to be met. Better communicating skills information to students is very important in this regard (OECD, 2018a). More effective career counselling is also instrumental. A new law for VET stipulates that vocational guidance will become part of the general education system and will be provided to children from the first grade. This is welcome.

Figure 29. The enrolment rates in VET are low

Share of vocational students on upper secondary students, 2015

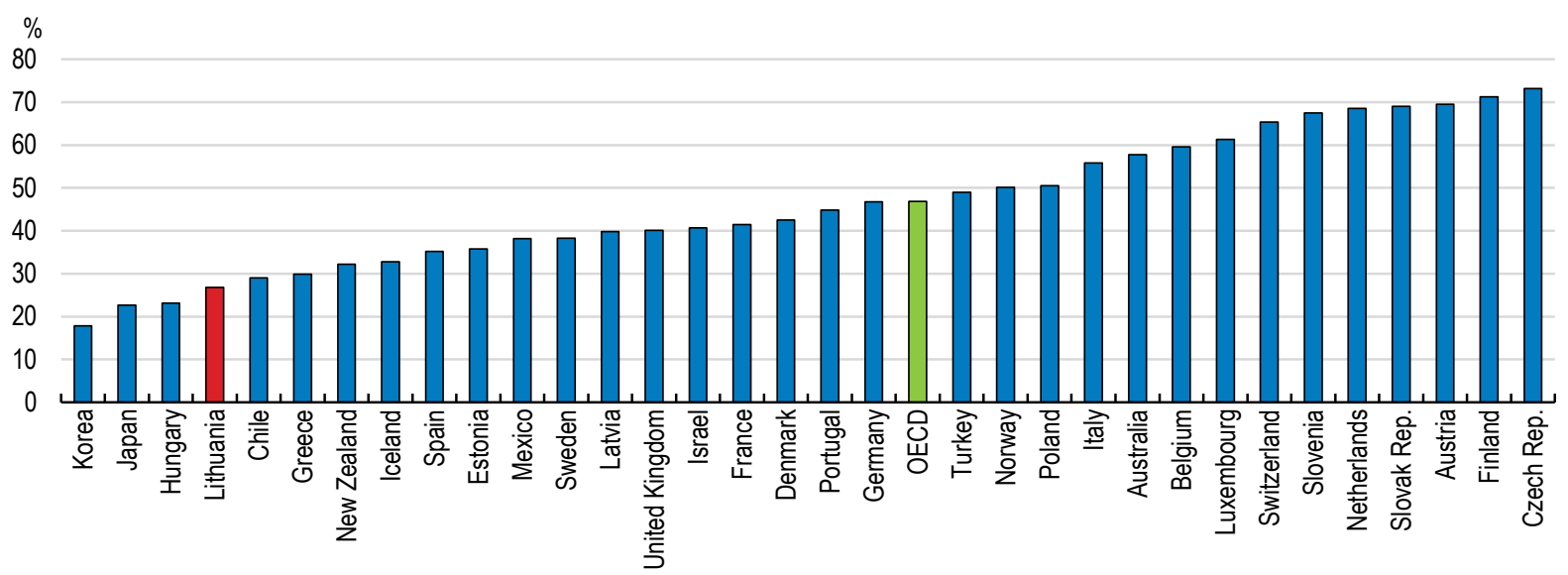

Source: OECD education at a Glance 2017.

StatLink ज्ञात http://dx.doi.org/10.1787/888933789460

Strengthening VET quality further hinges upon reforms that increase the capacity and incentives of schools to provide more work-based training. Consideration should be given, in this context, making work experience a prerequisite for entry into vocational teaching, as recommended by the 2017 OECD Review of Education for Lithuania (OECD, 2017g). Moreover, the current funding system for VET, which links public funds to the student enrolments, could be reformed to recognise and reward work-based instruction of vocational students. To ensure good quality of teaching in VET, a new law requires external school audit every 5 years and the supervision of non-formal vocational training. Increasing the quality of general education teaching offered to secondary vocational students, would also raise the attractiveness of VET (OECD, 2017g). Ongoing reforms aimed at improving basic skills development in general education and enhancing alignment between general, VET and tertiary education should continue.

Apprenticeships are not widespread in Lithuania. The new Labour Code (see below), in force since July 2017, clarifies the legal status of apprenticeships and provides for two types of apprenticeship employment contracts: one with a contract for formal or non-formal training; and one without such a contract. The maximum duration for an apprenticeship is 6 months, apart from the case that this entails a training contract of a longer period. A part 
of the training expenses incurred by the employer can be reimbursed through the wage of the apprentice if the two parties involved in the apprenticeship contact agree on it. No more than $20 \%$ of the apprentice's monthly remuneration can be allocated to reimburse such expenses. The new Law on Employment also includes measures to support apprenticeship, providing in particular for wage subsidies as a compensation for the training costs incurred by employers in the case that they employ job-seekers registered at the local labour exchange (public employment service). The apprenticeship system could be strengthened, including by moving from time-based to competence-based apprenticeships, which links success to the acquisition of knowledge and skills (OECD, 2018a). This is the case for instance in Australia and the United Kingdom. Complementary measures that further encourage participation by businesses may also be necessary. Widening the options of financial support for companies through, for example, cost-sharing mechanisms or joint apprenticeship programmes, available in some countries, would be beneficial (OECD, 2018a). Plans by the government to introduce a "dual system" of VET education, along with a flexible system of recognition of qualifications, go in the right direction and could be guided by international experience. Increased capacity of firms to provide structured training in the workplace is vital in this regard.

Dealing with the inadequacy of skills further requires addressing deficiencies in the education at early stage and ensuring strong soft skills, such as critical thinking, problem solving and teamwork. Education performance, as measured by PISA (OECD Programme for International Student Assessment) is below OECD average (OECD, 2017g). Ongoing reforms in all sectors of the education system are therefore welcome. Basic skills are also important for participating in the digital economy (OECD, 2017e). A large share of population in Lithuania lacks basic problem-solving skills in technology-rich environment, which may weaken job prospects, though younger people are better prepared than their older counterparts (Figure 30).

Figure 30. There is need to strengthen basic skills for the digital working environment

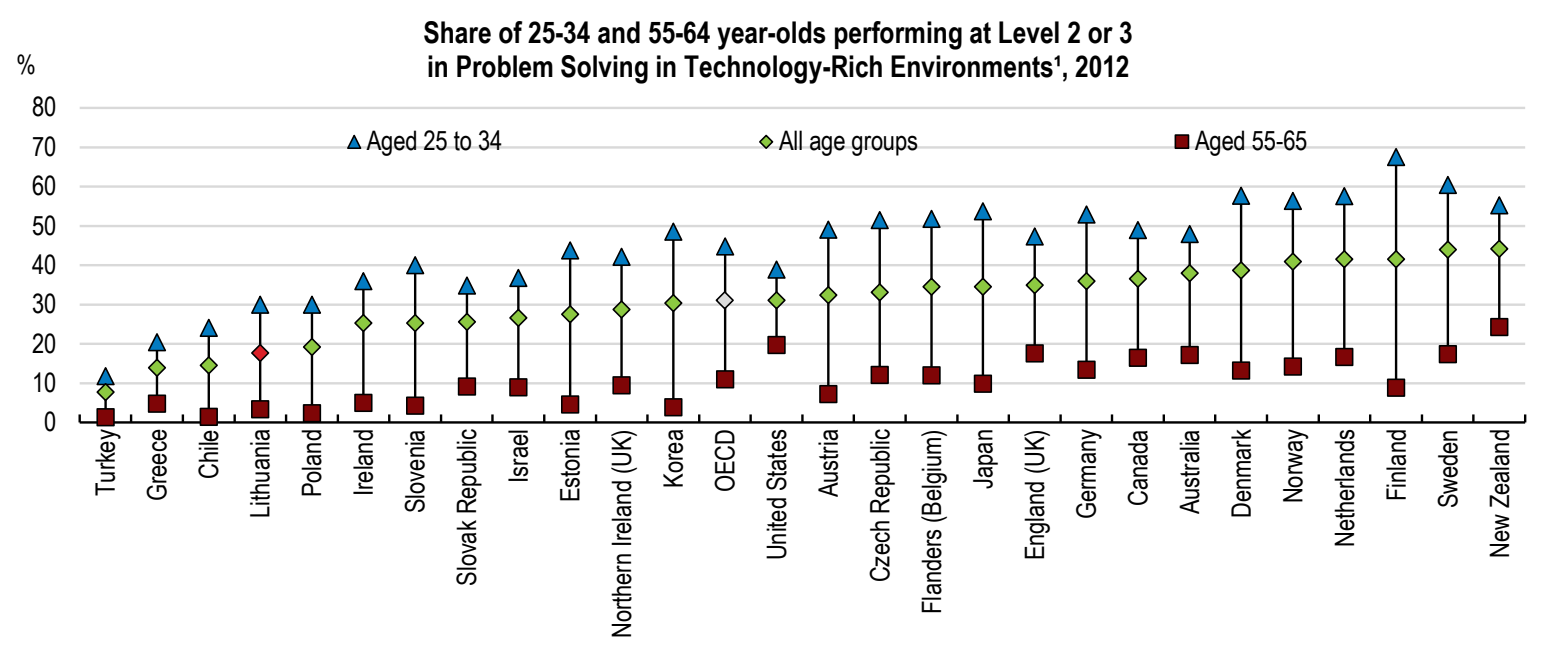

1. Level 3 corresponds to a score between 291 and 340 and Level 2 to a score between 341 and 500. At levels 2 and 3, tasks typically require the use of both generic and more specific technology applications. Source: OECD (2015e), Survey of Adult Skills (PIAAC) (2015). 


\section{Making the labour market more inclusive through more and better jobs}

A new Labour Code came into force in July 2017 as part of a broader reform package referred to as the "New Social Model" (see Box 1, Assessment and Recommendations of the 2018 Economic Survey of Lithuania). The new labour law relaxed the rules on individual dismissal for employees with a permanent contract and shortened the notice and severance pay periods for those employees (Figure 31, Panel A). A central fund, financed from $0.5 \%$ contribution by employers on their wage bill, will provide supplementary severance pay for workers with long tenure ( 5 years or more), with the amount increasing with the length of service. The 2017 law also lifted restrictions on the use of temporary employment contracts (Figure 31, Panel B), which accounted for only $2 \%$ of employees in 2016, especially youth (OECD, 2017h). As a safeguard, the new Labour Code requires that such contracts should not account for more than $20 \%$ of the total for a given employer; in addition, while they can be successive, fixed-contracts can be used only for a specific period for a given employee. A new set of employment contracts was further introduced, including for apprentices (see above) and project-based employment contracts, and working-time arrangements were relaxed (OECD, 2018a).

Figure 31. Employment protection legislation was eased

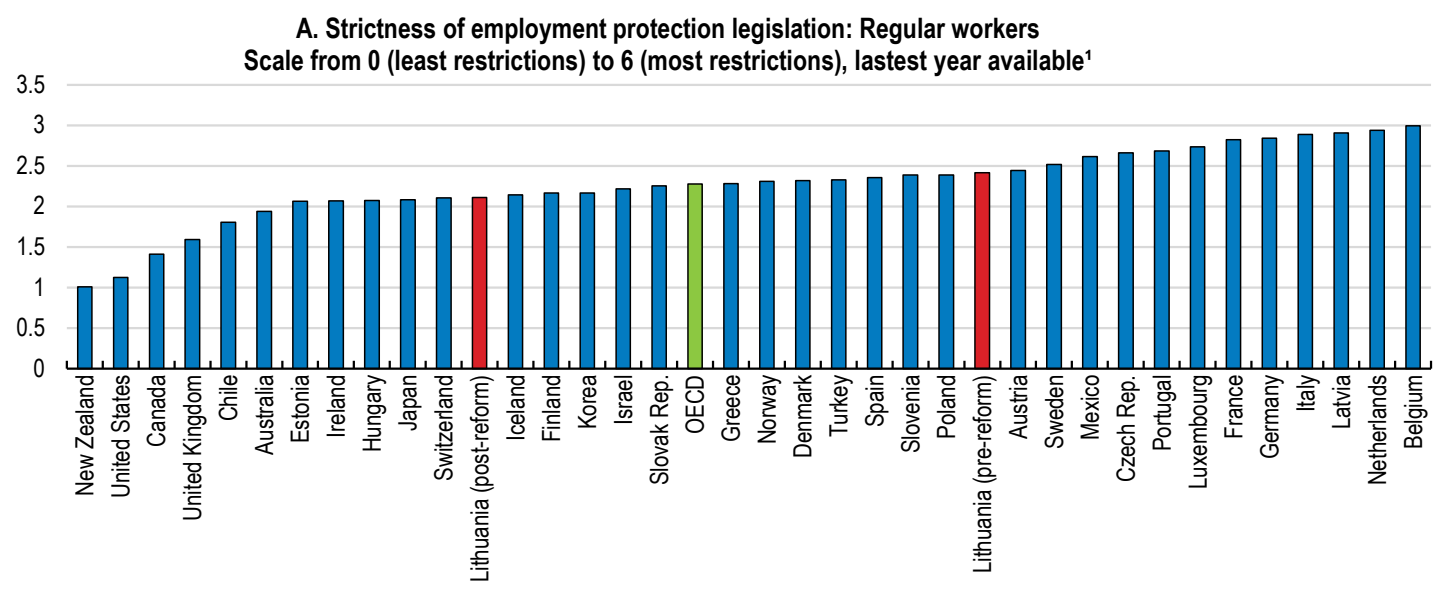

B. Strictness of employment protection legislation: Temporary employment Scale from 0 (least restrictions) to 6 (most restrictions), last year available ${ }^{1}$

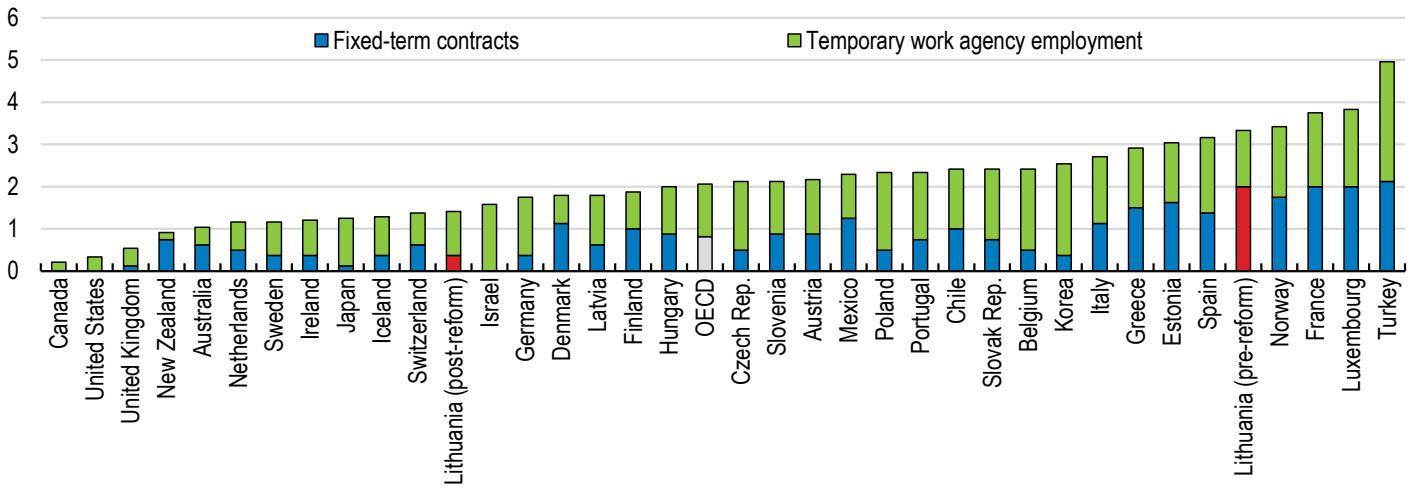

1. 2013 except 2014 for Slovenia and the United Kingdom and 2015 for Latvia.

Source: OECD (2018), OECD Reviews of Labour Market and Social Policies: Lithuania, OECD Publishing, Paris.

StatLink הत्गाड https://doi.org/10.1787/888933789498 
Overall, labour relations became more flexible under these new provisions. Lithuania's restrictiveness of both permanent and temporary employment protection regulation (EPL) now stands below the OECD average (Figure 31). The reform is expected to lead to higher productivity growth by promoting a more efficient allocation of resources (OECD, 2016f; Andrews and Cingano, 2014). In the shorter term, there may be some employment losses but also a reduction in informality and increase in inclusiveness as less strict labour regulations lower the cost of formal employment (OECD, 2008; 2018a). Other provisions of the new Labour Code could also help to reduce labour market informality, such as the requirement for employers with 20 or more employees to establish work remuneration systems, which increases wage transparency.

Protecting workers from circumventions of formal regulations is essential for inclusiveness and well-being. For example, between 2010 and 2013, less than $10 \%$ of total dismissed workers received severance pay according to available data (European Commission, 2015). Enforcement of the new law would also boost labour market efficiency and investment by increasing certainty for firms about work practices (European Commission, 2017b). As a positive move, the State Labour Inspectorate (SLI) will now also be responsible for monitoring the practical enforcement of the new law and evaluate its impact. To this end, the SLI will be in charge of collecting a range of data, including on the number of breaches and labour contract terminations, and the grounds for the latter, as well as the number of actions filed in court regarding labour disputes. Ensuring adequate resources for SLI to meet its expanded functions is important. A comprehensive dataset is essential to monitor the implementation of the new labour code and identify possible areas for further improvement. Consideration could be given in strengthening the sanctions in case of law infringement, as they could be too low (OECD, 2018a).

Size-dependent exemptions from the requirements of the new labour law require attention. For instance, firms with less than 10 employees, accounting for more than $90 \%$ of total enterprises in Lithuania (Figure 32), are exempted from the obligation to approve the selection criteria for redundancy or to provide information to their employees regarding the company's situation in terms of fixed-term contracts and temporary work. In addition, these firms are not obliged to provide a payment of study leave for employees participating in non-formal training. Size-dependent policies come with the risk of increasing the incentives for firms to remain small or to underreport workers (OECD, 2016e). Moreover, too generous exemptions may impact job quality. Assessing regularly as to whether the safeguards of the new Labour Code are sufficient to minimise the risks for an increase in labour market duality is essential. 
Figure 32. Distribution of enterprises by size

Distribution of entreprises by size, 2015 or latest year available

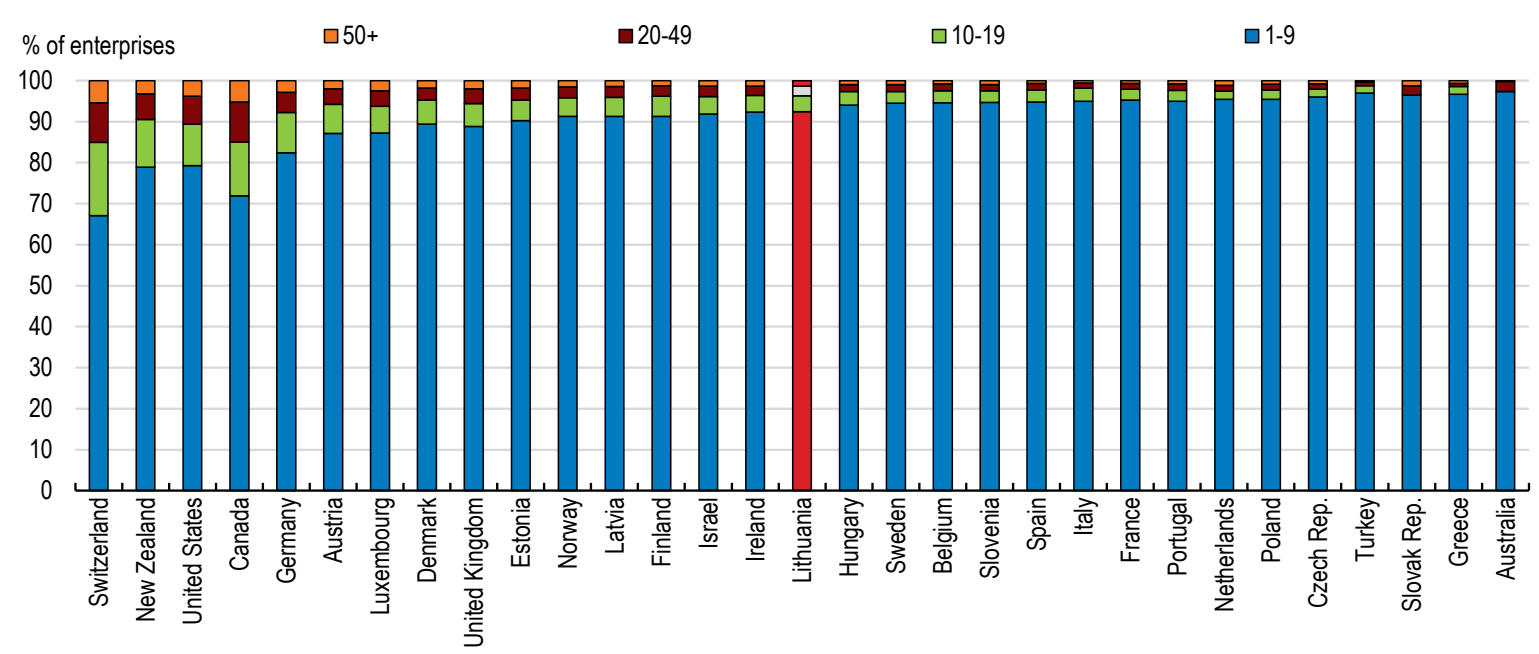

Source: OECD Structural and Demographic Business Statistics.

StatLink ज्ञाज https://doi.org/10.1787/888933789517

\section{Improving the employability for those with lower skills}

Providing more job opportunities for the less-skilled workers is instrumental for an inclusive labour market (Figure 10). The high tax wedge (measuring the difference between labour costs to the employer and the corresponding net take-home pay of the employee) makes such workers less attractive to employers (Figure 33). Recent empirical evidence suggests that, in the Baltic countries a 10 percentage point reduction in the tax wedge would reduce the level of structural unemployment by 2 to 4 percentage points on average (Ebeke and Everaet, 2014). In addition to its adverse impact on employment, high labour taxation might also curb work incentives for the low-skilled and increase incentives for informal activities. Recent increases in the personal income tax threshold are a welcome step towards reducing the tax burden at the bottom of the wage distribution, but a reduction in high social insurance contributions would have been even more important, while ensuring that benefits are maintained (Figure 33). Reliable information on wages is critical for targeting effectively the low-skilled and containing budgetary costs. As a welcome step, the State Social Insurance Fund Board has started since early 2017 to make public the data on average wages in enterprises and institutions.

In the medium-to-longer term, the best way to ensure more and better quality jobs for the low skilled is through measures that improve their productivity, and hence their career advancement, including through an educational and training system that matches skills to labour needs and effective life-long learning programmes for workers' upskilling. Only 6\% of workers participated in lifelong learning in 2017, almost half the level in EU (see Chapter 2 of the 2018 Economic Survey of Lithuania). Measures under the new Labour Code, including the right to leave for training and the recent introduction of commuting support (for a three-month period) for jobseekers participating in subsidised employment programmes in distant places, are steps in the right direction. The latter is also expected to reduce training barriers for jobseekers in rural and remote areas, where unemployment rates tend to be higher (Figure 10). 
Figure 33. The tax wedge is high

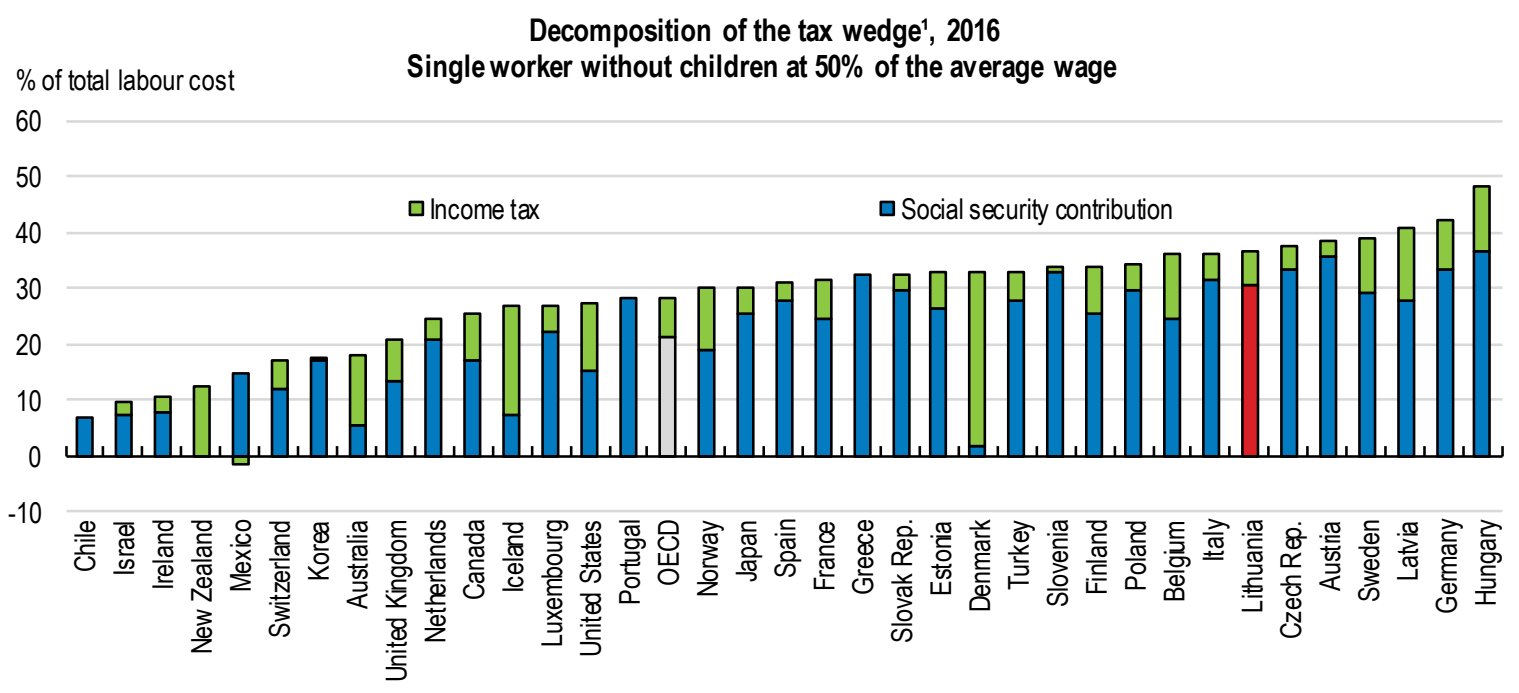

1. Average tax wedge on labour income.

Source: OECD taxing wages database.

StatLink त्गाSम http://dx.doi.org/10.1787/888933788700

\section{Income support for the unemployed has increased}

In tandem with increased flexibility, reforms under the New Social Model (see Assessment and Recommendations of the 2018 Economic Survey of Lithuania) provide for increased income security ("flexicurity"). Only $30 \%$ of the unemployed were covered by the insurance system before the reform, reflecting the long minimum contribution periods required (OECD, 2018a). This imposed constraints especially on youth or people with interrupted work paths. The new provisions reduce the required contribution period for benefit entitlement from 18 months in the last 36 months to 12 months in the last 30 months. They also increase the generosity of the benefits by extending their duration to 9 months, regardless of contribution history; and, by raising payment rates. The link between benefits and previously received earnings has been reinforced. These changes are expected to increase the coverage of the registered jobseekers by $15 \%$ and bring the net replacement rate (i.e. the share of previous net earnings replaced through unemployment benefits) above the OECD average (OECD, 2018a) (Figure 34). Indicatively, the share of unemployment insurance benefit recipients in total registered unemployed increased from $29 \%$ in January 2017 (before the reform) to more than 33\% a year after, while the average amount of unemployment insurance benefit increased by almost 1.5 times. This should contribute to poverty reduction and willingness of workers to change jobs, boosting inclusiveness. It may also make formal employment more attractive.

Around $40 \%$ of households in Lithuania fall below the poverty risk threshold in case of job loss (OECD, 2016e). The maximum duration period of unemployment benefit could be further extended. Most of OECD countries pay unemployment benefits for at least twelve months (OECD, 2018a). Such reform could be funded, for example, through a reduction in replacement rates in the initial months of an unemployment spell, when they are generous in international comparison (Figure 34), as recommended by the 2018 OECD Reviews of Labour Market and Social Policies: Lithuania (OECD, 2018a). This would strengthen the support for long term-unemployed, who accounted for close to $40 \%$ of unemployed in 2016, while ensuring that they effectively re-integrate in the labour market. 
Figure 34. Unemployment benefits became more generous

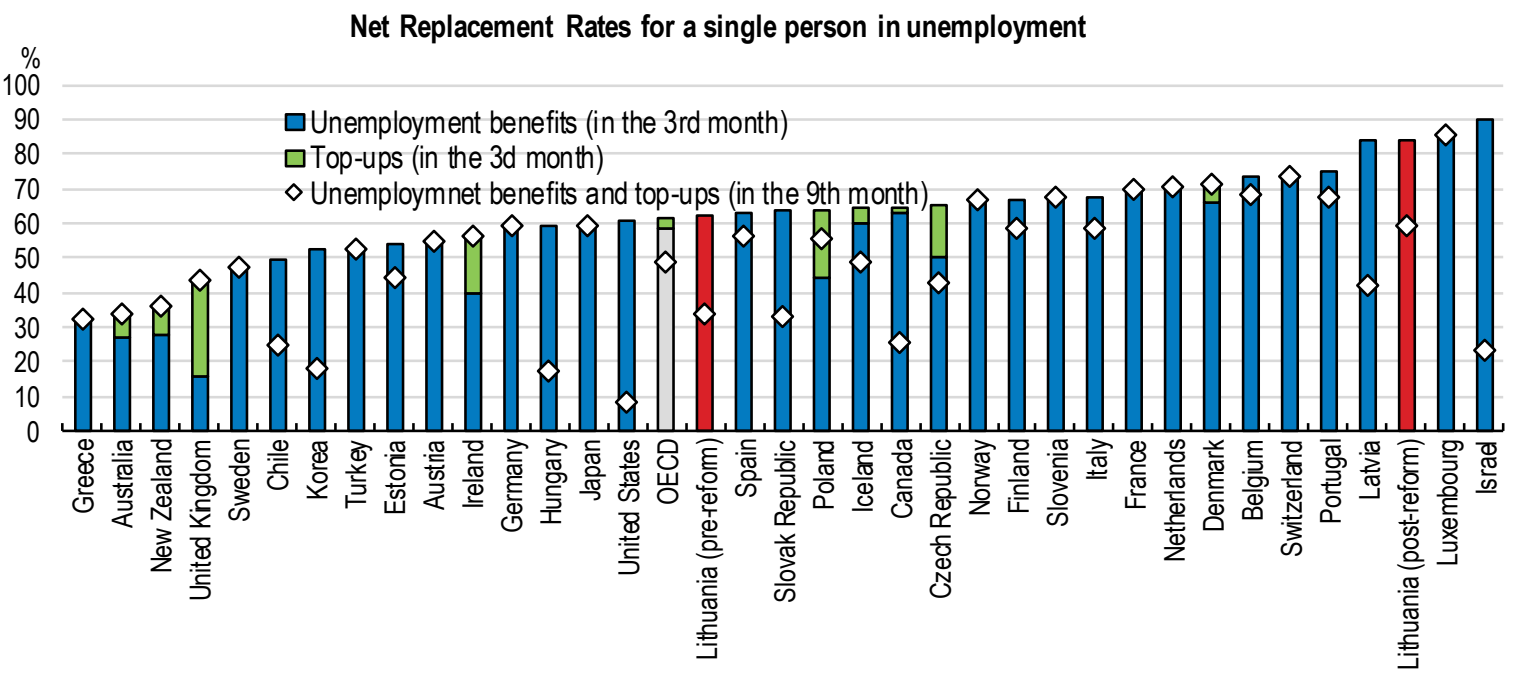

Note: Net replacement rates (NRRs) give the case of a 40 -years-old who has been continuously employed since the age of 18. For Lithuania, the results for January and July 2017 represent the situation before and after introduction of the New Social Model, respectively; for all the other countries the data refer to 2015.

Source: OECD (2018), OECD Reviews of Labour Market and Social Policies: Lithuania, OECD Publishing, Paris.

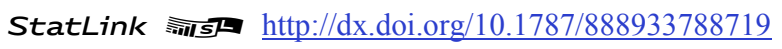

\section{Combating poverty more effectively}

As a complementary reform, the minimum-income benefits scheme needs to be strengthened to combat high inequality and poverty more effectively. While the receipt rate of social benefits is higher than before the global financial crisis, the payment levels are not sufficient to significantly alleviate or prevent poverty, even larger households which are eligible for higher social payments (Figure 35 Panels A and C). In 2014, Lithuania spent around $0.3 \%$ of GDP on minimum-income benefits, above Estonia and Latvia, but with some room for catching up with the OECD average (OECD, 2018a). 
Figure 35. Receipt of social benefits increased but support remains weak
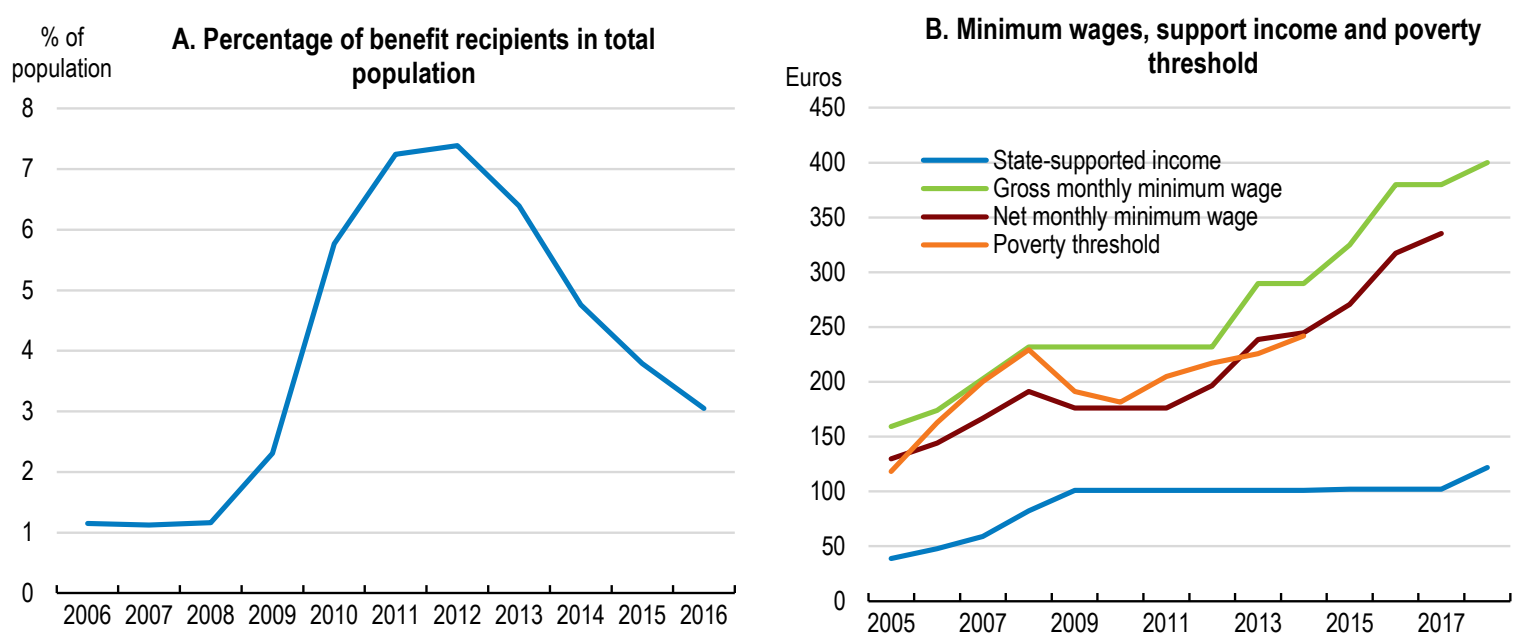

C. Net income from minimum-income benefits as a \% of the median equivalised household income, by

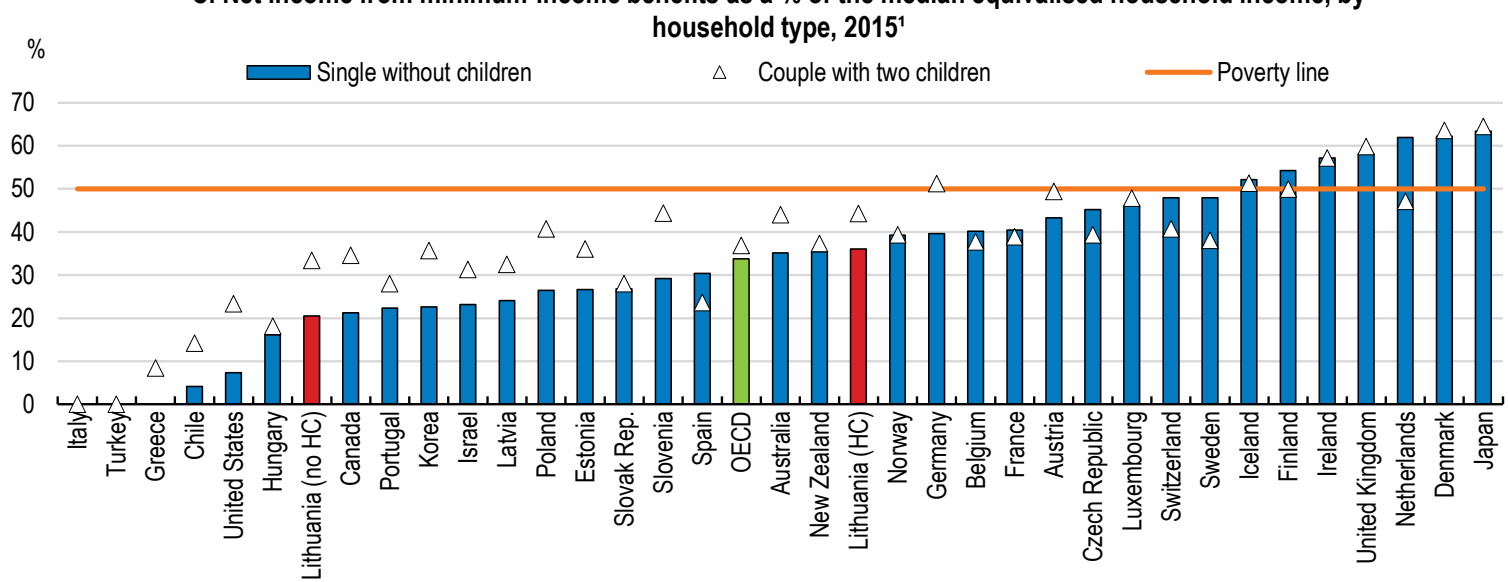

1. 2017 for Lithuania, with Heating Compensation ("Lithuania (HC)") and without ("Lithuania (no HC)").

Source: OECD (2018), OECD Reviews of Labour Market and Social Policies: Lithuania, OECD Publishing, Paris.

StatLink त्ञाज https://doi.org/10.1787/888933789536

Recent reforms attempt to raise income support adequacy. In particular, the amount of state-supported income, which determines the eligibility for social assistance, was increased by approximately $20 \%$ in early 2018 (Box 2). Moreover, a recent law links social benefits to the amount of minimum consumption needs. These measures are welcome, especially in view of the decline in the purchasing power of social benefit recipients in recent years, estimated by OECD (2018a) at around 8\% between 2009 and 2016. The impact of the new measures in terms of poverty reduction needs to be closely monitored. Regular updates of the level of the amount of minimum consumption needs are important. Consideration might be given to the regional differentiation of the benefits (OECD, 2018a).

Child poverty remains an important issue, with a risk of a vicious cycle between socioeconomic background and economic opportunities (OECD, 2017a). Around 19\% of the children live in relative poverty with an income below $50 \%$ of the median, above the OECD the average and other Baltic countries and Poland (Figure 36). Children in Lithuania are 
more likely to live in poverty than the general population, with the likelihood of being poor linked closely to the employment status of an adult in the household. To address child poverty better, the government introduced a universal child benefit replacing the former child tax allowance from 2018. Moreover, the child benefit will not be included in the income establishing family's eligibility for social assistance (Box 2). The government expects that at risk-of-poverty rate of children will decrease by about 2.7 percentage points as a result of these measures. These reforms are accompanied by efforts to improve the quality of services by social workers.

Figure 36. Child income poverty rates are high, especially in jobless households
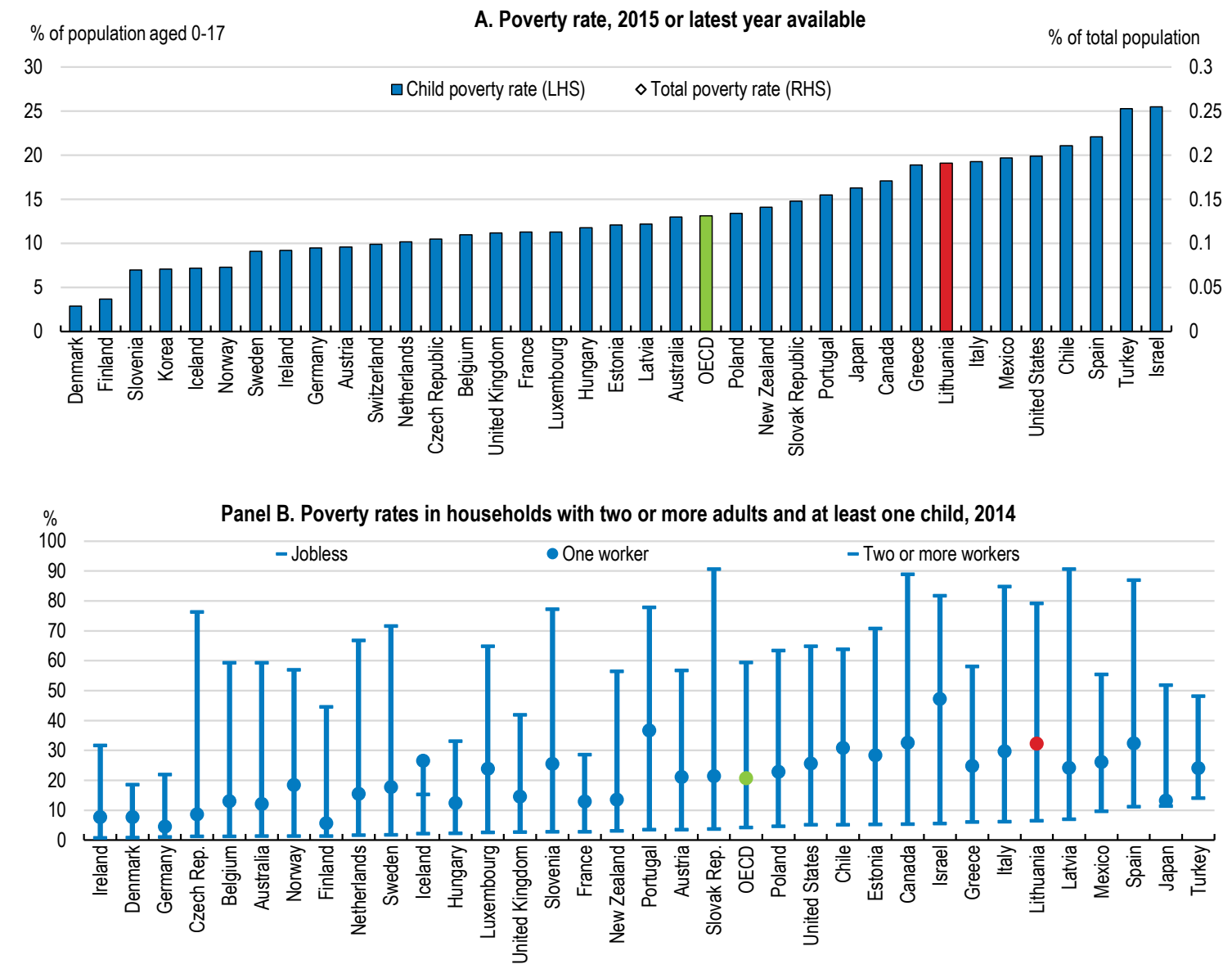

Note: The child income poverty rate is defined as the proportion of children ( $0-17$ year-olds) with an equivalised post-tax-and-transfer income of less than $50 \%$ of the national annual median equivalised post-tax-and-transfer income

Source: OECD Income Distribution and Poverty database.

StatLink त्ञात्र http://dx.doi.org/10.1787/888933788738 


\section{Box 2. Social assistance and in-work benefits schemes: main features}

\section{Social assistance}

Lithuania provides last-resort income support to low-income households through its Cash Social Assistance scheme, including for those jobseekers without unemployment entitlements. The scheme includes two components: Social Benefits and the Heating Compensation (covering compensation of heating, drinking and hot water costs). Social benefits are means-tested and granted if the monthly income is below the level of statesupported income (SSI). The Heating Compensation, is paid if heating costs exceed more than $10 \%$ of the differences between household income and the SSI (OECD, 2018a).

The social benefit for a single person, or the first member in the household, is equal to $100 \%$ of the difference between the SSI and the actual income of the household; $80 \%$ of the difference for the second member; and, $70 \%$ for the third and any additional household member. Before 2012, 90\% of the SSI income was applied for all members of the household. Employable recipients who do not study or work have to register as jobseekers at the local public employment service.

Payments are reduced over time. In particular, employable long-term recipients face a reduction after every 12 months on benefits, up to a maximum of $50 \%$ after 48 months. Since 2016, benefit recipients who have not been offered a job or participation in an active labour market programme, as well as those involved in community work, are exempt from these reductions. Benefits are paid in-kind after 60 months (OECD, 2018a).

The cash social assistance system is administrated and funded by municipalities since 2015 , following a comprehensive reform over the period 2012-2015. Every municipality currently receives an annual lump-sum to cover benefit payments, the amount of which is determined by the average benefit expenditures in the specific municipality in the three years before the reform.

\section{In-work benefits}

Lithuania has introduced in 2012 in-work benefits for long term unemployed (registered as unemployed for at least 12 months) recipients of social benefits. Recent reforms extended the coverage of in-work benefits. As from September 2016, those registered as unemployed for at least six months and start working are allowed to keep half of their previous assistance benefits for six months if the new job pays between one and two times the monthly minimum wage.

An income disregard was introduced in early 2018 as part of amendments to the Law on Cash Social Assistance for poor residents at end-2017. This permits recipients who work to keep some of their earnings. The part of income to be excluded varies with the composition of family and the number of children, ranging from $15 \%$ in the case of single persons to $35 \%$ for individuals with three or more children. In addition, the child benefit will not be included in the income establishing family's eligibility for social assistance. The government expects that about 50 thousand persons will benefit from these measures in 2018, either by becoming eligible for social benefit or by being granted an increase in the benefit level. 
A major challenge when increasing the level of income support to better protect those in need is to ensure that financial incentives to work are not reduced. The low level of social benefits in Lithuania and the increasing gap vis-a-vis minimum wages imply that the financial incentives to take up a job are relatively large (Figure 35, Panel B). Yet, as with other countries, the withdrawal of benefits when the recipient takes up a job makes employment less attractive and may also increase incentives for informal work. This is also supported by evidence showing that the disincentives to work are stronger at the bottom of the income distribution (Navicke and Lazutka, 2016). The financial incentives to work are weaker for larger households as the benefit level rises with every additional household member (Figure 37). Hence, the family benefits only little if one partner takes up a job. Moreover, the standard calculations of participation tax rates do not take into account inkind support, such as free childcare and school lunches, provided to low-paid families by the municipalities, and hence probably underestimate the risk for recipients with children of entering an inactivity trap (OECD, 2018a).

In-work benefits are an effective tool for increasing the financial incentives to work for low-income individuals, according to international experience (Immervoll and Pearson, 2009). When properly designed, such schemes can reduce inequality at the same time as increasing employment. Lithuania has introduced in 2012 in work-benefits for long-term unemployed recipients of social benefits, extending their coverage more recently (Box Box 2). Around $11 \%$ of social benefit recipients registered with the Public Employment Service received this support in 2015 compared to 5.3\% in 2014 (OECD, 2018a). The impact of in-work benefit scheme on incentives to work needs to be evaluated. Consideration could be given, if legally feasible, to give municipalities, who fund the scheme, more leeway to change its parameters according to the local circumstances, as is recommended by the 2018 OECD Review of Labour Market and Social Policies: Lithuania (OECD, 2018a). Allowing local differentiation, for instance in the coverage or duration of in-work benefits, could increase the responsiveness, and hence effectiveness, of the measure.

An income disregard was introduced in 2018 as a further step to increase financial incentives to work (Box 2). This increases the level of earnings at which singles and couples are eligible for social assistance by not taking into account a part of the recipient household's work income when establishing eligibility for the assistance. A number of countries are implementing income disregards in their social assistance programs, including Finland, Portugal and the Slovak Republic (Navicke et al., 2016). By permitting recipients who work to keep some of their earnings, such measure increases an individual's incentives to take up a job, even part-time. Its impact in reducing poverty needs to be regularly evaluated. The recent reforms of the work-benefit scheme, as well as of social benefits, should be accompanied by strengthened job search support and active labour market programmes. 
Figure 37. Financial incentives to take up a job are weaker for large households

Participation tax rates for a person taking up employment at the 20th percentile of the gross earnings distribution

\section{A. Single without children}

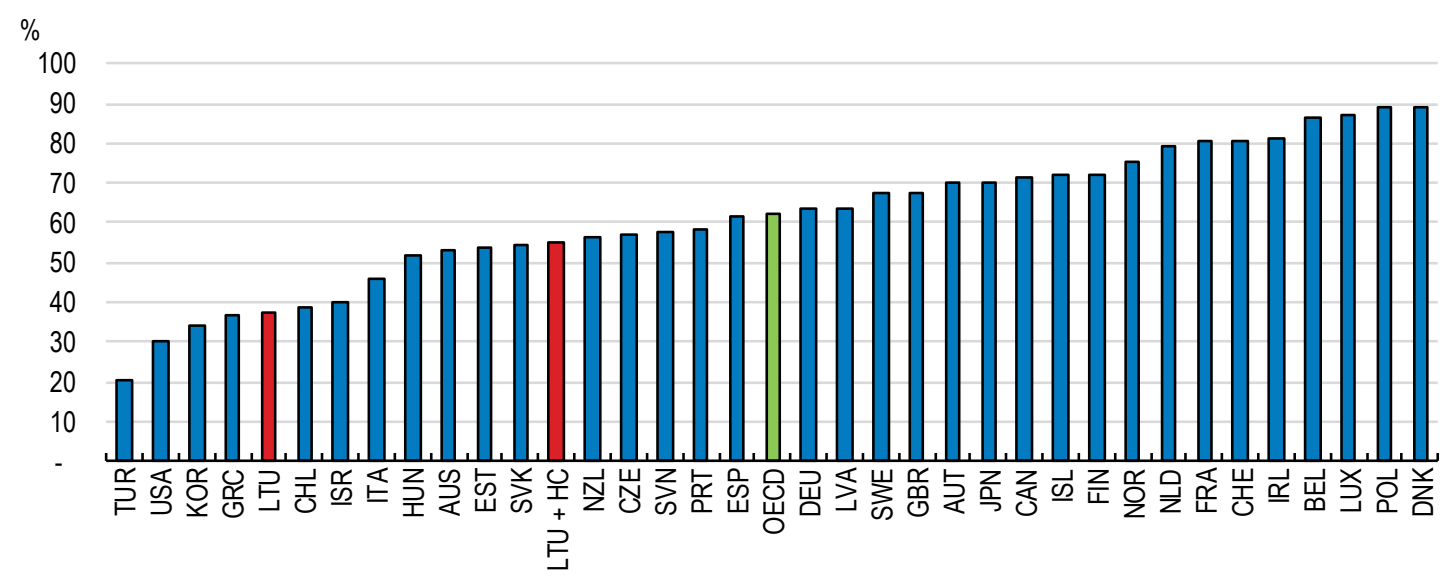

B. Couple with 2 children

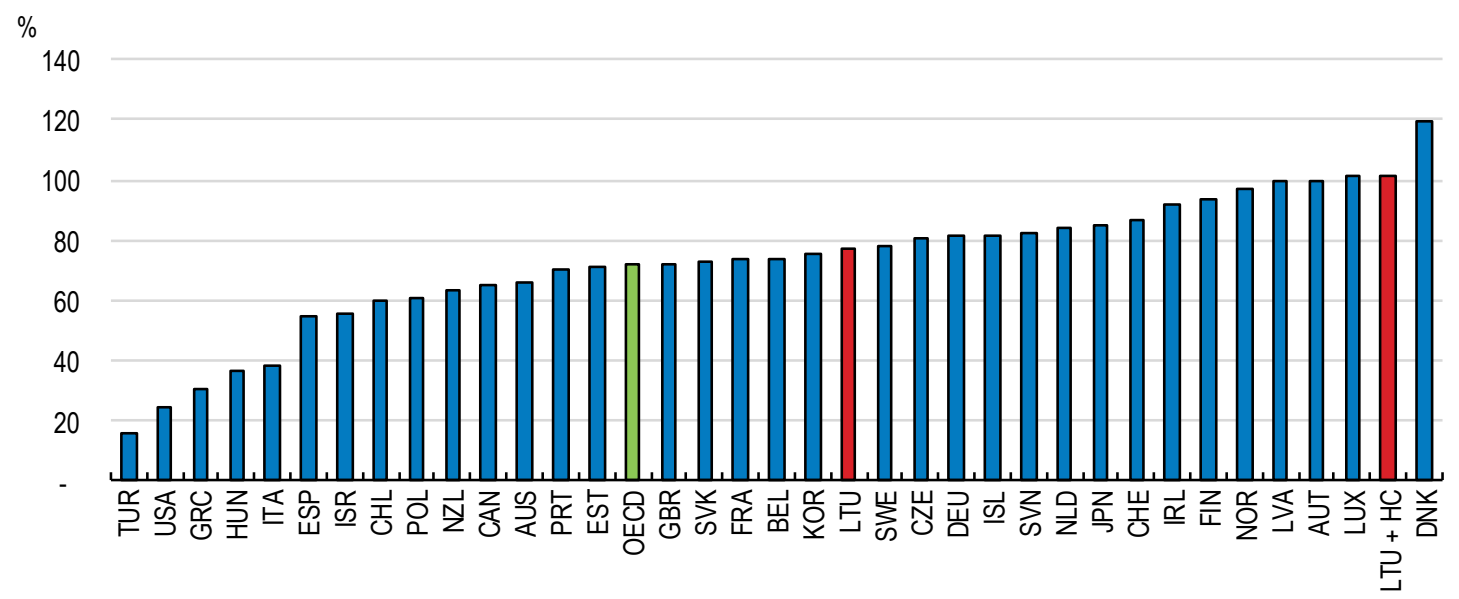

Note: The participation tax rate is calculated as the income gain from taking up work net of taxes, contributions and losses in benefit payments as a share of the gross earnings from work. For Lithuania, the values refer to those for households receiving Social Benefits only (LTU) and social benefits plus heating compensation (LTU + HC). In the latter case, the calculations assume that the heating compensation is lost when a person takes up work. The data refer to 2015 except for Lithuania (July 2017). The 20th percentile of the gross earnings distribution corresponds to about EUR 440 per month.

Source: OECD (2018), OECD Reviews of Labour Market and Social Policies: Lithuania, OECD Publishing, Paris.

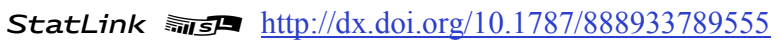

\section{Helping jobseekers to get back to work through effective training and re- training}

Well-designed activation policies can foster inclusive growth by helping the most vulnerable to find a job. The high structural unemployment rate in Lithuania and more flexible EPL rules under the new code reinforce the need. Spending on active labour marker 
policies (ALMPs), and participation in such programmes, is relatively low in international comparisons (Figure 38, Panels A and B).

Moreover, Lithuania's public employment services (PES), delivered by the Labour Exchange Office, is understaffed with a heavy workload per employee (Figure 38, Panel C); depending on the region, the caseload per frontline PES staff varies between 130 and 180 jobseekers (OECD, 2018a). This makes it difficult to provide intensive personalised services, such as frequent individual interviews and updated action plans over the unemployment spell, which have been proved critical for a successful re-integration in the labour market and better skill matches (OECD, 2015e). A small share of jobseekers in Lithuania find a job through the PES (Pacifico, 2017), despite its wide use as a source of information on job vacancies, indicating scope for more efficiency.

Recent reforms have changed the structure of public employment services by centralising the management processes of activities planning and of financial and human resources. The new PES structure (from October 2018), along with change brought from the new Employment Law, is expected to reduce the administrative functions at local level and release some resources, increasing in turn the provision of direct services to jobseekers. The foreseen equalisation of workloads of PES staff across counties is welcome. However, intensive personalised PES services require that the number of suitably trained officers is increased; this is also vital for the reform of employment service delivery underway (OECD, 2018a).

The structure of ALMP programmes has also changed recently. The new Employment Law that came into force in July 2017 expands the range of ALMPs and attempts to increase efficiency by reallocating spending among programmes. Public works, which have proven ineffective in boosting employment, have been abolished. Spending on ALMPs in Lithuania appears too tilted towards wage subsidies at the expense of programmes that boost long-term employability, notably training (Figure 38, Panel D). Wage subsidies can be efficient at improving the employability of low skilled rather quickly but they may have only short-lived effects and may involve large deadweight losses (when hiring would have occurred in the absence of the subsidy), even though cost-efficiency could be improved by targeting the subsidies to the most vulnerable groups (OECD, 2016e). Participation in training, on the other hand, has proven to boost employability and the quality of jobs in the medium- to long-term (Card et al., 2015).

More systematic evaluation of the active labour market programmes is essential for a close monitoring of the achieved outcomes. As a positive step, since 2014, the Lithuanian PES assesses the performance of ALMPs on the basis of sustainability and return on investment, taking also into account the wage an ALMP participant receives when finding a job. However, the evaluation analysis has been undertaken only for some programmes, particularly those co-financed by the EU. Systematic data collection on the outcomes of the various ALMP programmes is key for a high-quality assessment of their effectiveness, although the difficulties in developing key performance indicators should not be underestimated. A close co-operation between PES, which are responsible for ALMPs, and municipalities that have responsibility for social assistance benefits, is also important to help to better tailor programmes to the participants' profiles, improving effectiveness and yielding inclusiveness gains. 
Figure 38. Expenditure on active labour market programmes
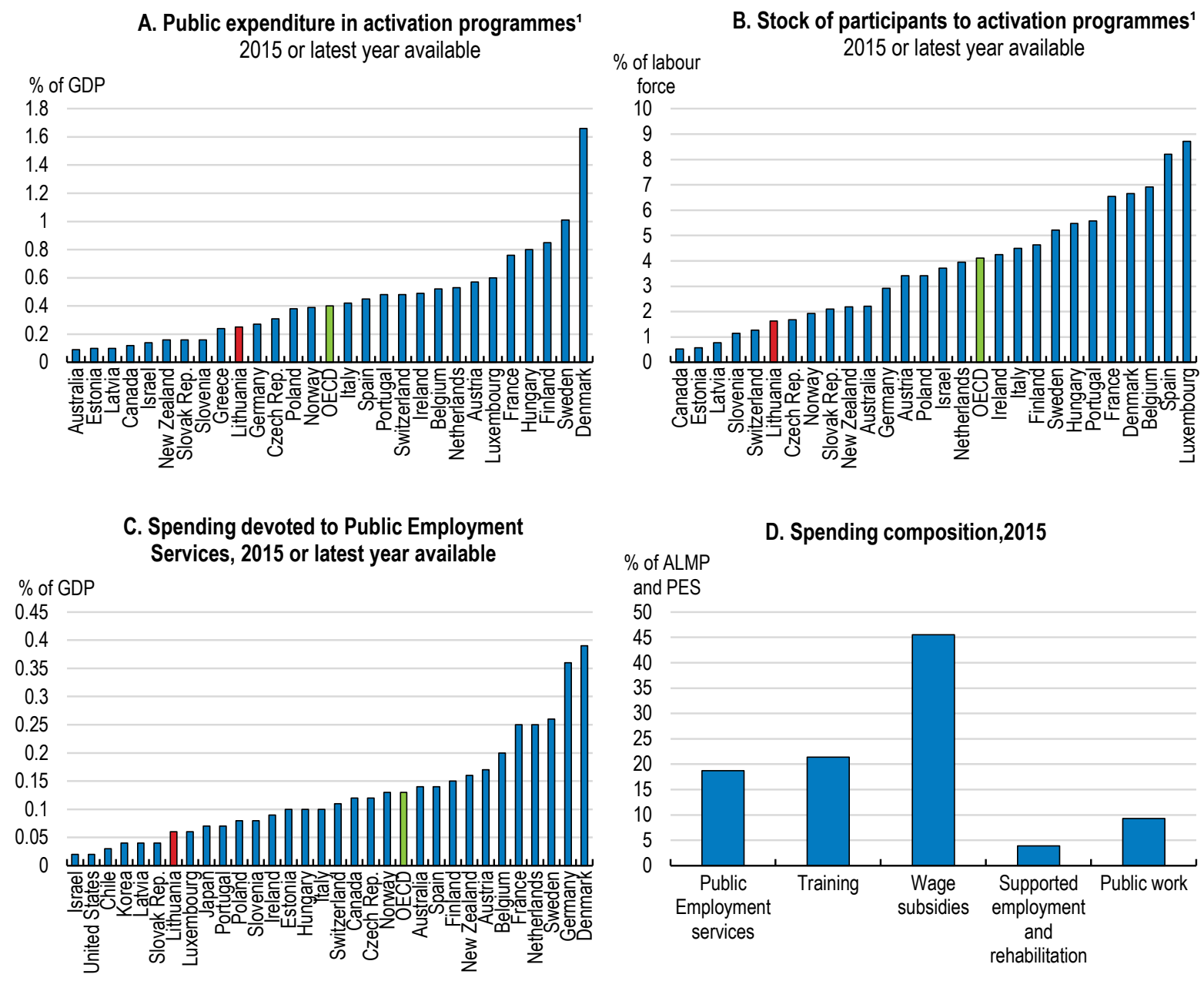

1. Active labour market programmes (categories 2-7) include: cover training, employment incentives, supported employment and rehabilitation, direct job creation and start-up incentives.

Source: OECD Labour database.

StatLink הत्ञाs https://doi.org/10.1787/888933789574 


\section{Box 3. Recommendations on raising productivity for inclusive growth}

Key recommendations:

- Strengthen the monitoring capacity of the Governance Coordination Centre, building on the recent increase in its budget.

- Simplify bankruptcy procedures and establish more favourable conditions for restructuring.

- Continue the implementation of the institutional reform of innovation policy by improving coordination, and consolidate agencies and support programmes where overlaps exist.

- Give more weight on collaborative research when allocating funds to public research institutions.

- Provide differentiated awards for tertiary courses with skills closely linked to labour market needs.

- Strengthen work-based learning, including by linking the length of apprenticeships to the level of acquired competencies.

- Continue with overall reform of the education system at all levels, addressing skills mismatch.

- Further increase the level of social assistance, while ensuring strong work incentives.

- Increase investment in active labour market programmes upon a close monitoring of their outcomes.

\section{Other recommendations:}

- Apply progressively to all key sectors of the economy the new methodology for the calculation of the compliance costs for business.

- Continue implementing reforms to strengthen the ownership function, increase the independence of SOE boards, streamline SOEs' corporate forms and improve disclosure practices.

- Strengthen the use of expertise, including through specialised judges and bankruptcy administrators.

- Make work experience a prerequisite for entry into vocational teaching and reform the funding system for vocational education and training to recognise and reward work-based instruction of students.

- Ensure adequate resources for the State Labour Inspectorate to meet its strengthened monitoring functions.

- Reduce the tax burden at the bottom of the wage distribution through a reduction in social security contributions, while ensuring that benefits are maintained.

- Update regularly the level of the amount of minimum consumption needs to ensure adequate income support to benefit recipients, and consider the introduction of regional differentiation in social benefits.

- Ensure a sufficient number of suitably trained officers in Public Employment Services to provide intensive personalised assistance for jobseekers. 


\section{References}

Adalet McGowan, M. and D. Andrews (2017), "Skills Mismatch, Productivity and Policies: Evidence from the Second Wave of PIAAC", OECD Economics Department Working Papers, No. 1403, OECD Publishing, Paris.

Adalet McGowan, M., D. Andrews, and V. Millot (2017), "The Walking Dead? Zombie Firms and Productivity Performance in OECD Countries", OECD Economics Department Working Papers, No. 1372, OECD Publishing, Paris.

Adalet McGowan, M. and D. Andrews (2016), "Insolvency Regimes and Productivity Growth: A Framework For Analysis", OECD Economics Department Working Papers, No. 1309, OECD Publishing, Paris.

Andrews, D. and F. Cingano (2014), "Public Policy and Resource Allocation: Evidence from firms in OECD Countries", Economic Policy, Issue 74 April.

Andrews, D., Criscuolo C., and P. N. Gal. (2016), "The Best versus the Rest: The Global Productivity Slowdown, Divergence across Firms and the Role of Public Policy", OECD Productivity Working Papers, 2016-05, OECD Publishing, Paris.

Australian Government (2016), "Delivering a High-Performing Research Sector in Australia: Watt Review Response", May.

de Avillez, R. (2012), "Sectoral Contributions to Labour Productivity Growth in Canada: Does the Choice of Decomposition Formula Matter?", International Productivity Monitor, Vol. 24.

Bank of Property (2017), State-Owned Enterprises in Lithuania - Annual Report, 2016, Turto Bankas.

Bank of Property (2016), State-Owned Enterprises in Lithuania - Annual Report, 2015, Turto Bankas.

Card, D., J. Kluve and A.Weber (2015), "WhatWorks? A Meta-Analysis of Recent Active Labour Market”, IZA Working Paper, No .9236.

Ebeke, C. and G. Everaert (2014), "Unemployment and Structural Unemployment in the Baltics", IMF Working Paper, No. 14/53.

European Commission (2017a), European Innovation Scoreboard 2017.

European Commission (2017b), “Country Report: Lithuania 2017”, Staff Working Document.

European Commission (2017c), Education and Training Monitor 2017: Lithuania, November.

European Commission (2016a), “Country Report: Lithuania 2016”, Staff Working Document.

European Commission (2016b), "Lithuania: Mismatch Priority Occupations", Skills Panorama, October.

European Commission (2015), Country Report Lithuania 2015, European Commission.

European Commission (2014), Special Eurobarometer 402 “Undeclared Work in the EU”, March.

Eurofound (2017), Sixth European Working Conditions Survey - Overview Report (2017 Update), Publications Office of the European Union, Luxembourg.

Gruzevskis, B. and I. Blaziene (2015), EEPO Country Fiches on Skills Governance in the Member States -- Lithuania, European Employment Policy Observatory, European Commission.

IMF (2017a), "Republic of Lithuania: Selected Issues", IMF Country Report 17/178.

IMF (2017b), "Republic of Lithuania: Article IV", IMF Country Report 17/177.

IMF (2016), "Republic of Lithuania: Selected Issues", IMF Country Report 16/126. 
Immervoll, H. and M. Pearson (2009), "A Good Time for Making Work Pay? Taking Stock of In-Work Benefits and Related Measures across the OECD", OECD Social, Employment and Migration Working Papers, No. 81, OECD Publishing, Paris.

Maggs, P. and I. Hathaway (2016), "Absorptive Capacity: Boosting Productivity in the Creative Industries", Frontier Economics, July.

MOSTA (2017), "Experts Recommend a Package of Reforms to Upgrade Lithuania's Research and Innovation Ecosystem", Research and Higher Education Monitoring and Analysis Centre, News, October.

NAO (National Audit Office) (2014), "Bankruptcies Are Initiated Too Late in Lithuania”, Press Release, December.

NAO (2016), Management of the Programme for Investment in 2015, No. VA-P-60-9-16, October (Executive Summary of the Public Audit Report in English).

Navicke, J., S. Avram and L. Demmou (2016), “The effects of reform scenarios for unemployment benefits and social assistance on financial incentives to work and poverty in Lithuania", OECD Economics Department Working Papers, No. 1310, OECD Publishing, Paris.

Navicke, J. and R. Lazutka (2016), "Work Incentives Across the Income Distribution and for Model Families in Lithuania: 2005-2013, Baltic Journal of Economics, pp. 16:2, 175-191.

OECD (2018a), OECD Reviews of Labour Market and Social Policies: Lithuania, OECD Publishing, Paris.

OECD (2018b), OECD Services Trade Restrictiveness Index: Policy Trends up to 2018, OECD Publishing, Paris.

OECD (2017a), Going for Growth, OECD Publishing, Paris.

OECD (2017b), "OECD Services Trade Restrictiveness Index (STRI): Lithuania", December.

OECD (2017c), The Size and Sectoral Distribution of State-Owned Enterprises, OECD Publishing, Paris.

OECD (2017d), OECD Economic Surveys: Japan, OECD Publishing, Paris.

OECD (2017e), "Going Digital: Making the Transformation Work for Growth and Well-Being", Meeting of the OECD Council at Ministerial Level, Paris, 7-8 June.

OECD (2017f), OECD Economic Surveys: Australia, OECD Publishing, Paris.

OECD (2017g), Education in Lithuania, Reviews of National Policies for Education, OECD Publishing, Paris.

OECD (2017h), OECD Employment Outlook, OECD Publishing, Paris.

OECD (2016a), OECD Reviews of Innovation Policy: Lithuania 2016, OECD Publishing, Paris.

OECD (2016b), "Promoting Productivity and Equality: A Twin Challenge", Economic Outlook, Volume 2016: Issue 1, OECD Publishing, Paris.

OECD (2016c), The Productivity-Inclusiveness Nexus, OECD Publishing, Paris.

OECD (2016d), "Corporate Governance: Reforming the State-Owned Enterprises Sector", Lithuania Policy Brief, March.

OECD (2016e), OECD Economic Surveys: Lithuania - Economic Assessment, OECD Publishing, Paris.

OECD (2016f), OECD Employment Outlook, OECD Publishing, Paris. 
OECD (2015a), Regulatory Policy in Lithuania: Focusing on the Delivery Side, OECD Reviews of Regulatory Reform, OECD Publishing, Paris.

OECD (2015b), OECD Review of the Corporate Governance of State-Owned Enterprises: Lithuania, OECD Publishing, Paris.

OECD (2015c), The Future of Productivity, OECD Publishing, Paris.

OECD (2015d), The Innovation Imperative: Contributing to Productivity, Growth and Well-Being, OECD Publishing, Paris.

OECD (2015e), “Activation Policies for More Inclusive Labour Markets" in Employment Outlook 2015, OECD Publishing, Paris.

OECD (2013), Interconnected Economies: Benefiting from Global Value Chains, OECD Publishing, Paris.

OECD (2008), "Declaring Work or Staying Underground: Informal Employment in Seven OECD Countries", Employment Outlook 2008, OECD Publishing, Paris.

Pacifico, D. (2017), Faces of Joblessness Lithuania: Main Results and Policy Inventory, OECD.

Schneider, F. (2016), "Estimating the Size of the Shadow Economies of Highly Developed Countries: Selected New Results”, CESifo DICE Report, ISSN 1613-6373, Vol 14, Issue 4, pp. 44-53.

Warda, J. (2001), "Measuring the Value of R\&D Tax Treatments in OECD Countries", STI Review No. 27: Special Issue on New Science and Technology Indicators, OECD Publishing, Paris.

World Bank (2018), Doing Business 2018: Reforming to Create Jobs, The World Bank Group.

World Bank (2017), Doing Business 2017: Equal Opportunity for All, The World Bank Group.

Vie, O.E, Stensli M., and T.A. Lauvas (2014), "Increasing Companies' Absorptive Capacity Through Participation in Collaborative Research Centres", Energy Procedia, 58, pp. 36 - 42.

Žukauskas, V. (2015), Shadow Economies in the Baltic Region 2015, Lithuanian Free Market Institute. 


\section{Annex A. Labour productivity growth: shift share analysis}

Shift-share analysis allows decomposing labour productivity growth into changes within and between sectors. Following de Avillez (2012), the labour productivity, defined as gross value added over employment, can be calculated as the sum of each sector labour productivity, weighted by its labour share:

$$
\frac{\Delta \mathrm{LP}_{\mathrm{t}}}{\mathrm{LP}_{\mathrm{t}-1}}=\sum_{\mathrm{i}} \frac{\Delta \mathrm{LP} \mathrm{P}_{\mathrm{it}}}{\mathrm{LP}_{\mathrm{it}-1}} \frac{\mathrm{Y}_{\mathrm{it}-1}}{\mathrm{Y}_{\mathrm{t}-1}}+\sum_{\mathrm{i}} \frac{\mathrm{LP}_{\mathrm{it}-1}}{\mathrm{LP}_{\mathrm{t}-1}}\left(\frac{\mathrm{L}_{\mathrm{it}}}{\mathrm{L}_{\mathrm{t}}}-\frac{\mathrm{L}_{\mathrm{it}-1}}{\mathrm{~L}_{\mathrm{t}-1}}\right)+\sum_{\mathrm{i}} \frac{\mathrm{LP}_{\mathrm{it}-1}}{\mathrm{LP}_{\mathrm{t}-1}} \Delta \frac{\mathrm{L}_{\mathrm{it}}}{\mathrm{L}_{\mathrm{t}}} \frac{\mathrm{LP}_{\mathrm{it}}-\mathrm{LP}_{\mathrm{it}-1}}{\mathrm{LP}_{\mathrm{it}-1}}
$$

In this equation, LPit is labour productivity in sector $i$ at time $t$; Lit is the number of workers in sector $i$ at time $t$; and $Y$ is the output, defined as the gross value added.

Therefore, the methodology enables disaggregating labour productivity into three components:

- Within-sector effect $(W)$ : this component measures the contribution to total productivity growth from productivity growth within sectors, capturing the reallocation between firms in the same sector as well as changes in efficiency at the sectoral level.

- Shift effect (SE): this component measures the contribution to total productivity growth from the movement of labour resources between sectors, assuming productivity levels in each sector are unchanged. This effect is positive when the sector's labour share increases.

- Cross-term effect (CT): this component also shows how labour productivity changes when workers move from the one sector to another, but it also takes into account the trends in labour productivity for each sector. In the case of Lithuania, this term is usually negative meaning that an increase in productivity growth is exhibited in shrinking sectors, which may reflect a structural adjustment.

The results of shift share analysis for the period 1997-2016 reveal that the within-sector effect is the main source of growth in Lithuania, accounting on average around 6.5 percentage points of annual productivity growth between 1997 and 2007. This means that most of the improvements in labour productivity in Lithuania take place within the sectors and that the productivity slowdown of recent years has been driven mainly by a deceleration in the efficiency growth within each sector, that is, it has its origins in the deceleration of productivity growth within each sector (Figure A.1).

The shift effect, however, has also contributed to productivity growth by around $2 \%$ between 1997 and 2007, helping to mitigate the occasional slowdown of the within-sector effect. The contribution has declined after the global financial crisis dampening the overall labour productivity growth. This reflects a weaker flow of workers toward sectors with labour productivity above the national average. If the labour shifted from the less to more productive sectors after the 2008 crisis to the same extent as before the crisis, total labour productivity growth would be at around $2.5 \%$ in 2016 (keeping the within-sector effect constant), compared to growth of less than half percent that year. 
Figure A.1. Shift-share analysis of labour productivity

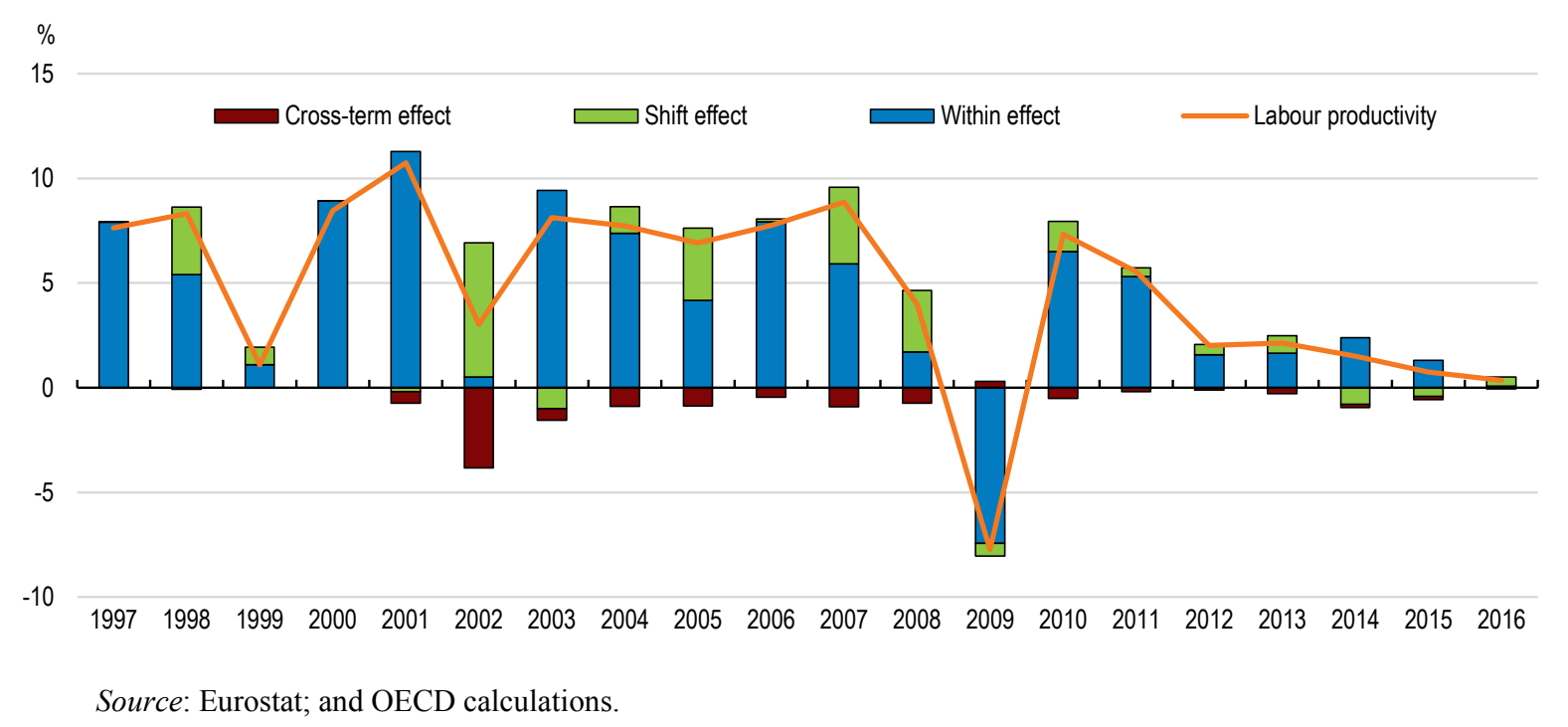

StatLink त्गाजम http://dx.doi.org/10.1787/88893378959 